Rodrigo Atique Ferraz de Toledo

\title{
Estudo funcional de células derivadas do periósteo portadoras da mutação p.S252W em FGFR2: alterações fenotípicas e moleculares
}

Functional analysis of periosteum derived cells bearing the FGFR2 p.S252W mutation: phenotypical and molecular alterations. 


\section{Rodrigo Atique Ferraz de Toledo}

Estudo funcional de células derivadas do periósteo portadoras da mutação p.S252W em FGFR2: Alterações fenotípicas e moleculares.

Functional analysis of periosteum derived cells bearing the FGFR2 p.S252W mutation: phenotypical and molecular alterations.

Dissertação apresentada ao Instituto de Biociências da Universidade de São Paulo, para a obtenção de Título de Mestre em Ciências, na Área de Biologia/Genética.

Orientadora: Maria Rita dos Santos e PassosBueno 


\section{Ficha Catalográfica}

Atique Ferraz de Toledo, Rodrigo

Estudo funcional de células derivadas do periósteo portadoras da mutação p.S252W em FGFR2: alterações fenotípicas e moleculares.

114 páginas

Dissertação (Mestrado) - Instituto de Biociências da Universidade de São Paulo. Departamento de Genética e Biologia Evolutiva.

1. Síndrome de Apert 2. Periósteo 3. FGFR2. Universidade de São Paulo. Instituto de Biociências. Departamento Genética e Biologia Evolutiva.

\section{Comissão Julgadora:}

Prof(a). Dr(a). $\quad$ Prof(a). Dr(a).

Prof(a). Dr.(a).

Orientador(a) 
Dedico essa dissertação à minha noiva Jóice Savietto, por todo o passado e futuro que iremos compartilhar. 
"When you make the finding yourself -even if you're the last person on Earth to see the light- you'll never forget it." 


\section{Agradecimentos}

Primeiramente, gostaria de agradecer à Prof. Maria Rita Passos-Bueno, não só por ser uma ótima orientadora, mas também por ser um exemplo de que é possível se fazer ciência de altíssima qualidade no Brasil.

Também gostaria de agradecer aos colegas de craniossinostoses Erika Yeh e Roberto Fanganiello, não só por me ensinarem pacientemente tudo o que sabem sobre as diversas formas sindrômicas e não sindrômicas, mas também pelas infindáveis discussões sobre ciência, tecnologia, política, faculdade, filosofia, gado ovídeo, entre outros não mencionáveis em uma publicação de decoro como esta.

Aos colegas de laboratório: Gerson, Bruno, Luciano, Carol, Lucas, Vanessa, Camila e Lígia, que apesar de não terem contribuído diretamente com a parte experimental, foram responsáveis pelas sextas à noite na Casa do Norte e na Rua Augusta, tão necessárias para a conclusão dessa dissertação quanto os próprios experimentos. Como diz o ditado popular: "Se cobrir chamam de circo, se cercar chamam de hospício". Também às agregadas Dyanna e Karine que se encaixaram como uma luva em nosso laboratório.

À May, Déinha e Letícia por dividirem as dores do Western Blotting comigo.

Aos demais colegas de laboratório: Danielle Moreira, Felipe, Cibele, Luciane, Melina, Francine, Cíntia, Eric, Maria Elisa, Joanna, Dani Bueno, Dani Yumi e Karina por todo o apoio psicológico que só quem está na academia pode prover, além de fazerem de nosso laboratório um local estimulante e agradável de se trabalhar. Às técnicas Simone e Larissa por garantir que o laboratório esteja sempre em condições de trabalho e pelas linhagens primárias fundamentais para nossa pesquisa. Também à equipe de sequenciamento do genoma, em especial à Meire Aguena e à Katia pelo suporte oferecido.

Aos coleguinhas de faculdade: Elaine, He-man, Camila, Maneco, Andrews, Vivi, Bruno, Fê Pinto, Babi, além dos atuais e antigos roomates: José Hernades, Fernando Belmonte e Marcelo Higa pelos momentos de descontração.

À minha noiva Jóice Savietto por ter me sugerido procurar por esse laboratório no fim da graduação e por estar sempre ao meu lado.

Aos meus pais por darem todo o apoio que eu sempre precisei e por nunca perguntarem quando eu ia começar a "trabalhar de verdade".

Este trabalho contou com o apoio financeiro da Fundação de Amparo à Pesquisa do Estado de São Paulo (FAPESP), do Conselho Nacional de Desenvolvimento Científico e Tecnológico (CNPq) e do Ministério da Ciência e Tecnologia do Brasil. 


\section{Índice}

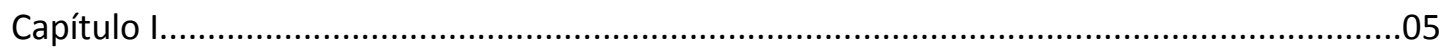

Introdução Geral

Capítulo II .28

FGFR2 MUTATION CONFERS A LESS DRASTIC GAIN OF FUNCTION IN MESENCHYMAL STEM CELLS THAN IN FIBROBLASTS

Capítulo III .63

CONTROL AND EFFECTS OF THE ALTERED EXPRESSION OF DUSP2 IN PERIOSTEUM DERIVED FIBROBLASTS FROM SYNDROMIC CRANIOSYNOSTOSIS PATIENTS.

Capítulo IV. 94

Discussão Geral

Capítulo V. 97

Resumo

Capítulo VI. 99

Abstract

Capítulo VII .101

Bibliografia 


\section{Capítulo I}

\section{Introdução Geral}

\section{Suturas Cranianas}

Suturas são articulações nas quais margens contínuas de osso se aproximam umas das outras e são unidas por uma fina camada de tecido fibroso (Gross, 1959). As principais suturas estão ilustradas na figura I.1. Durante o nascimento transvaginal, as suturas permitem o movimento dos ossos cranianos de modo que o crânio possa se ajustar à pressão que ocorre sobre ele durante a passagem pelo canal vaginal. Durante a infância, enquanto o desenvolvimento do encéfalo ocorre, exceto a sutura frontal, todas as outras suturas cranianas continuam abertas. Também especula-se que as suturas ajudem a absorver pequenos estresses mecânicos durante a infância (Cohen Jr. et al., 2000) .

A principal característica do crânio humano é o formato resultante do lento e neotênico desenvolvimento craniano combinado a um crescimento rápido e hipermórfico do encéfalo (Zollikofer et al., 2010), de forma que o crescimento do neurocrânio acompanha o do encéfalo.

As suturas são o principal centro de crescimento do crânio, e até que se atinja a maturação sexual desempenham um papel importante no desenvolvimento do indivíduo. Durante o aumento do encéfalo as suturas regulam o crescimento do crânio ao regular o balanço entre proliferação e diferenciação das células osteogênicas (Slater et al., 2008; A. O. Wilkie, 1997) 

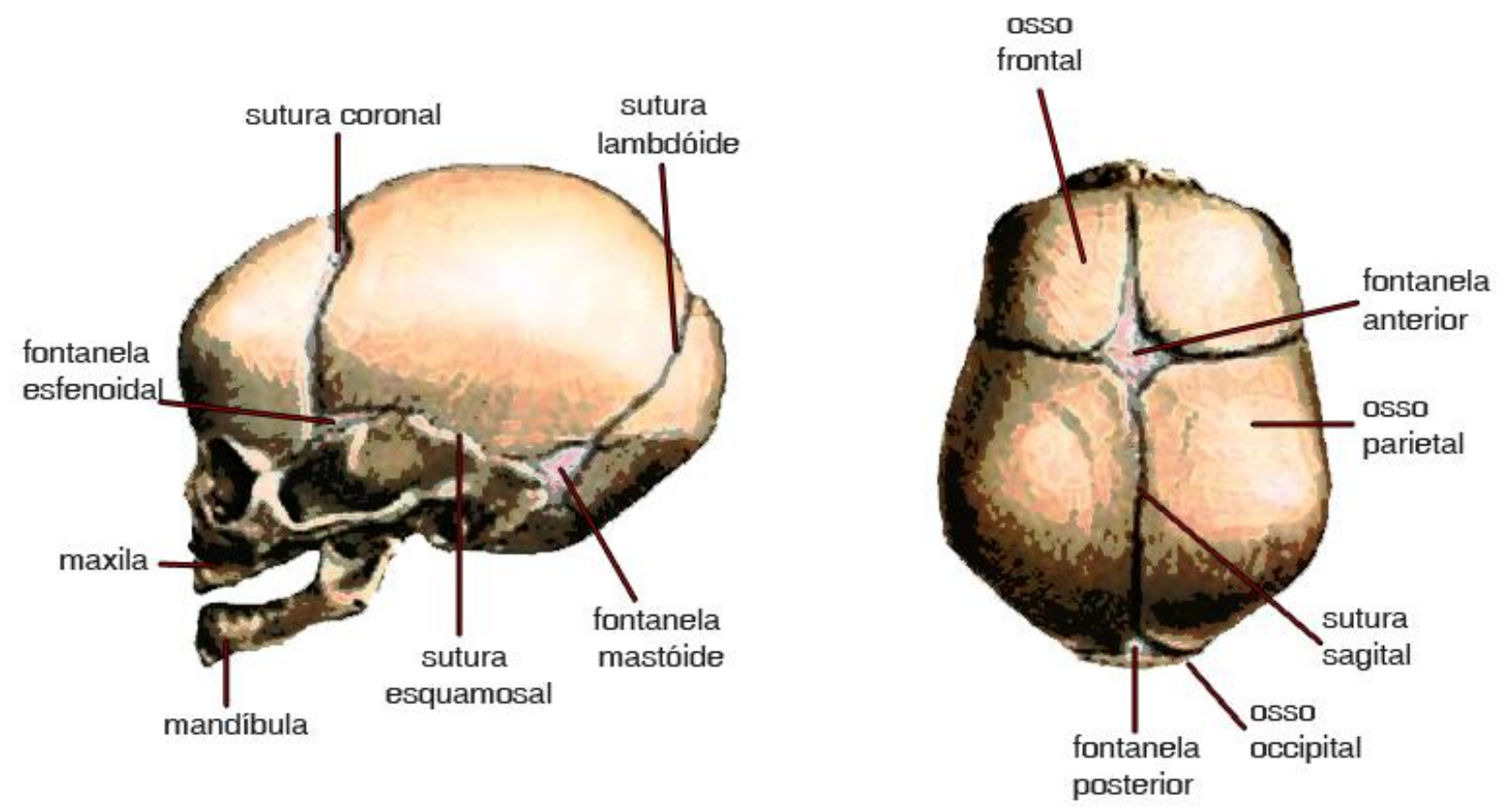

Figura I.1: Principais suturas do e ossos do crânio humano.

Durante o desenvolvimento, as suturas passam de limites lineares entre os ossos para complexas estruturas interdigitadas(Miura et al., 2009). As suturas eventualmente se fundem em diferentes períodos da vida de um individuo conforme detalhado na Tabela I. 1. Vale ressaltar que a sutura metópica normalmente é obliterada antes do terceiro ano de vida na maior parte dos casos(Cohen Jr. et al., 2000), ao contrário das outras suturas que só iniciam a fusão na vida adulta.

Tabela I.1 Idade de Fechamento das suturas

\begin{tabular}{|l|l|}
\hline Sutura craniana & $\begin{array}{l}\text { Idade média de início } \\
\text { de fechamento (anos) }\end{array}$ \\
\hline Metópica & 2 \\
Sagital & 22 \\
Coronal & 24 \\
\hline Lambdóide & 26 \\
\hline Esquamosal & $35-39$ \\
Esfenoparietal & 29 \\
\hline Esfenotemporal & $28-32$ \\
\hline Masto-occipital & $26-30$ \\
\hline
\end{tabular}


No segundo mês de gestação se inicia a formação intramembranosa dos ossos cranianos a partir da formação de blastemas mesenquimais(Aubin et al., 1996; Cohen Jr. et al., 2000; Langille, 1994; L A Opperman, 2000), cujas células começam a diferenciar e depositar colágenos e proteoglicanas (Ninomiya et al., 1990) que promovem a mineralização da matriz extracelular. A ossificação intramembranosa decorre radialmente a partir destes focos mesenquimais (Alberius et al., 1992). As bordas de cada osso estão largamente separadas e vão se aproximando, até que se sobrepõem, formando as suturas (L A Opperman, 2000). Durante o desenvolvimento das suturas, as frentes ósseas crescem e se expandem, invadindo e recrutando o tecido mesenquimal interveniente. Por volta do $50^{\circ}$ dia de gestação em humanos, começa a separação do mesênquima em duas camadas pelos ossos em expansão: o periósteo na parte externa e dura-máter na porção interna (Artun et al., 1986).

Assim a sutura craniana é um complexo formado pelo periósteo sobrejacente, as frentes osteogênicas das placas ósseas, o mesênquima interveniente e a dura-máter subjacente (Figura I.2). Nas duas últimas décadas, estudos têm fornecido evidências para a potencial influência da dura-máter e do periósteo sobre o fechamento das suturas cranianas. Foi observado em ratos e coelhos que a remoção da dura-máter leva a aceleração ou atraso no fechamento da sutura, dependendo de qual sutura a duramáter é retirada(Levine et al., 1998; Lynne A Opperman et al., 1993; Roth et al., 1996). Da mesma forma, a excisão do periósteo diminui a calcificação de defeitos cranianos em modelos animais (Ozerdem et al., 2003). 


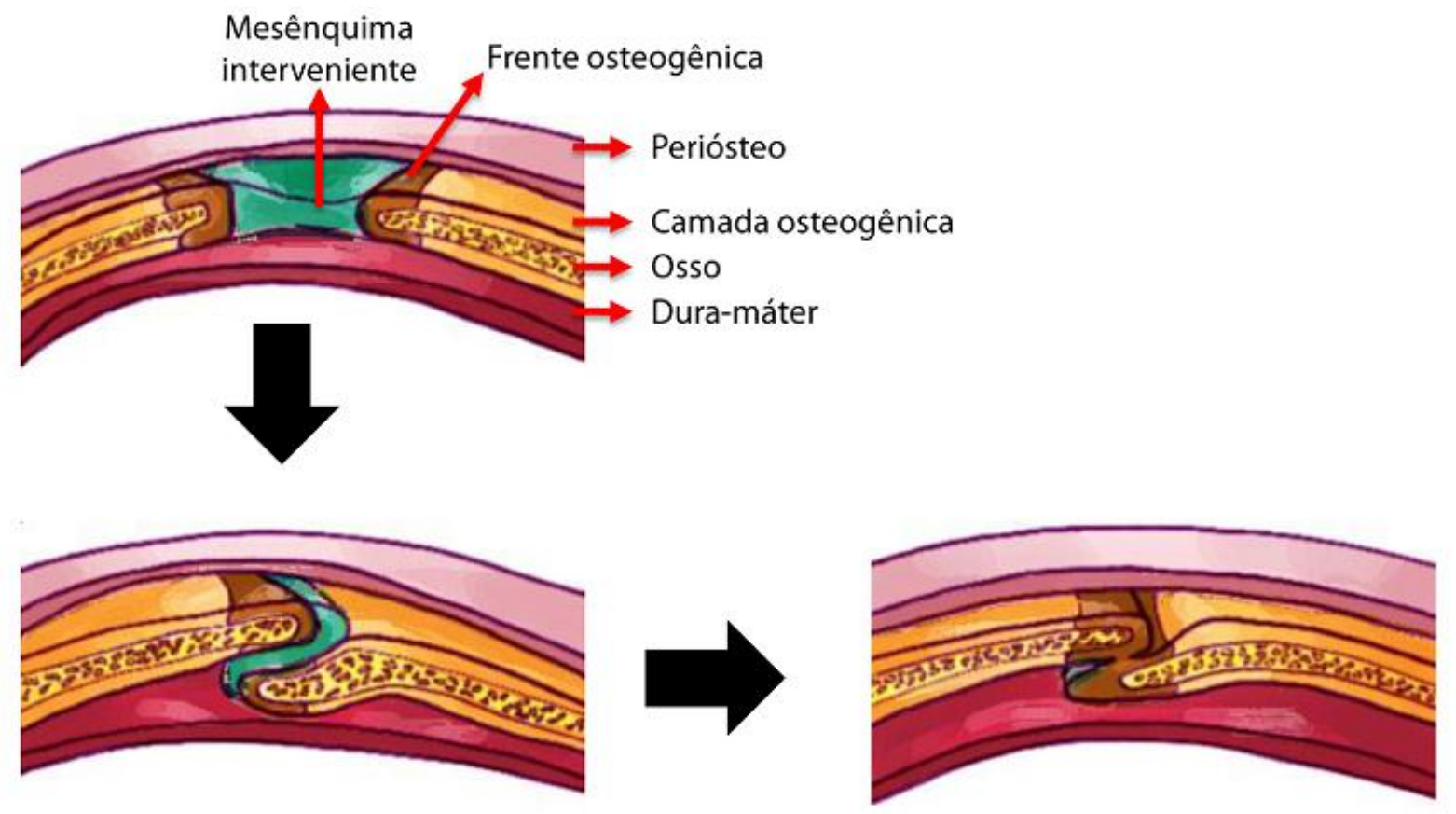

Figura I.2: Corte transversal de uma sutura crâniana. A sutura é revestida na porção superior pelo periósteo e na porção inferior pela dura-máter. O fechamento da sutura ocorre por deposição óssea nas frentes osteogênicas. Os sinais indutivos de ossificação garantem que elas desviem uma da outra, sem obliteração da sutura (verde). Estes sinais são independentes de sinais de dura-máter ou osso. Quando as frentes ósseas sobrepõem uma a outra, sinalização provenientedo periósteo (rosa) e da dura-máter (vermelho) mantém a presença da sutura recémformada (verde). Os ossos tornam-se espessados por depósito de osteóide e mineralização de novo na superfície periosteal, até que a sutura é fusionada. Adaptado de E. Yeh, 2011.

\section{Craniossinostoses}

As craniossinostoses, doenças que acometem 1 em cada 2.500 crianças nascidas, são resultantes da ossificação prematura de uma ou mais suturas cranianas e levam a alteração do formato do crânio e /ou no fechamento precoce das fontanelas cranianas. A fusão prematura das suturas pode ocorrer antes ou depois do nascimento, sendo que, quanto mais cedo a sinostose ocorrer, maiores serão os efeitos no formato do crânio(M Michael Cohen, 1986). As craniosinostoses podem ser caracterizadas como simples (envolvendo 1 sutura) ou complexas (envolvendo 2 ou mais suturas), primária ( causada por um defeito intrínseco da sutura) ou secundária (fechamento precoce da sutura causado por outra condição 
médica, como deficiências no crescimento do encéfalo). Podem ser ainda classificadas como isolada ou não sindrômicas (ocorrendo sem outras anomalias) ou como sindrômicas (ocorrendo junto à outros dismorfismos ou defeitos no desenvolvimento)(Kimonis et al., 2007)

O fechamento precoce das suturas cranianas muitas vezes pode causar comprometimento de perfusões encefálicas, obstrução de vias aéreas, comprometimento de visão e audição, dificuldades de aprendizagem, deformidades estéticas significativamente graves e alta pressão intracraniana(A. O. M. Wilkie et al., 2010). O único tratamento disponível para indivíduos com craniossinostose são as intervenções cirúrgicas, que pode requerer mais de uma intervenção e implica no uso de múltiplos procedimentos(David Johnson, 2003). Sem a intervenção cirúrgica para reabrir as suturas fundidas e reordenar os ossos cranianos, a pressão sobre o córtex cerebral em crescimento pode comprometer a inteligência do indivíduo, a função visual podendo ainda causar outras complicações neurológicas(Renier et al., 1996).

\section{Aspectos genéticos das craniossinostoses}

As craniossinostoses correspondem a um grupo heterogêneo de doenças, podendo ser causadas por fatores ambientais e/ou genéticos. Pouco se sabe sobre a etiologia das formas não sindrômicas. Porém entre as sindrômicas, alterações cromossômicas são responsáveis por cerca de 20 a $40 \%$ dos casos e alterações em genes específicos por cerca de $40 \%$ dos casos (F. S. Jehee et al., 2008; A. O. M. Wilkie et al., 2010). Até o momento, mutações em 7 genes foram associadas a ocorrência das craniossinostoses (Tabela I.2), e mutações no gene FGFR2 são as mais prevalentes entre as formas mendelianas de craniossinostose sindrômica. Apesar de que o mecanismo genético para cerca de $50 \%$ 
das craniossinotoses já tenha sido elucidado, pouco se conhece ainda quanto as vias de sinalização celulares comprometidas nestes casos. A compreensão das vias de sinalização celulares envolvidas nestas síndromes pode contribuir para a identificação de genes importantes para ossificação bem como para desenvolvimento de futuras terapias para este grupo de doenças.

Tabela I.2. Genes e Fenótipos associados à Craniossinostose (M. Passos-Bueno et al., 2008)

\begin{tabular}{|c|c|c|c|c|c|}
\hline Gene & $\begin{array}{l}\text { Símbolo } \\
\text { do gene }\end{array}$ & $\begin{array}{c}\text { Cromos } \\
\text { somo }\end{array}$ & Fenótipos & $\begin{array}{l}\text { Padrão de } \\
\text { Herança }\end{array}$ & $\begin{array}{l}\text { Penetrância da } \\
\text { craniossinostose }\end{array}$ \\
\hline \multirow[t]{2}{*}{$\begin{array}{l}\text { Receptor do fator } \\
\text { de crescimento de } \\
\text { Fibroblasto } 1\end{array}$} & FGFR1 & $\begin{array}{c}\text { 8p11.2- } \\
\text { p11.1 }\end{array}$ & Pfeiffer & $\begin{array}{l}\text { Autossômico } \\
\text { dominante }\end{array}$ & Alta \\
\hline & & & Displasia osteoglofonica & $\begin{array}{l}\text { Autossomico } \\
\text { dominante }\end{array}$ & $\begin{array}{c}\text { Aparentemente } \\
\text { alta }\end{array}$ \\
\hline \multirow{10}{*}{$\begin{array}{l}\text { Receptor do fator } \\
\text { de crescimento de } \\
\text { Fibroblasto } 2\end{array}$} & FGFR2 & $10 q 26$ & Crouzon & $\begin{array}{l}\text { Autossomico } \\
\text { dominante }\end{array}$ & Alta \\
\hline & & & Crouzon com scafocefalia & & \\
\hline & & & Jackson-Weiss & $\begin{array}{l}\text { Autossômico } \\
\text { dominante }\end{array}$ & Alta \\
\hline & & & Pfeiffer & $\begin{array}{l}\text { Autossômico } \\
\text { dominante }\end{array}$ & Alta \\
\hline & & & Apert & $\begin{array}{l}\text { Autossômico } \\
\text { dominante }\end{array}$ & Alta \\
\hline & & & SCS like & & \\
\hline & & & $\begin{array}{l}\text { Sindrome de cutis gyrata de } \\
\text { Beare-Stevenson }\end{array}$ & & Alta \\
\hline & & & Antley-Bixley & $\begin{array}{l}\text { Autossômica } \\
\text { recessiva }\end{array}$ & $\begin{array}{c}\text { Aparentemente } \\
\text { alta }\end{array}$ \\
\hline & & & $\begin{array}{l}\text { Síndromes não classificáveis } \\
\text { com craniossinostose }\end{array}$ & & \\
\hline & & & $\begin{array}{l}\text { Sinostoses coronais não- } \\
\text { sindrômicas }\end{array}$ & & \\
\hline \multirow{5}{*}{$\begin{array}{l}\text { Receptor do fator } \\
\text { de crescimento de } \\
\text { Fibroblasto } 3\end{array}$} & FGFR3 & $4 p 16.3$ & Síndrome de Muenke & & Alta \\
\hline & & & $\begin{array}{l}\text { Síndrome de Crouzon com } \\
\text { achantosis nigricans }\end{array}$ & & \\
\hline & & & SCS like & & \\
\hline & & & Displasia tanatoforica tipo I & $\begin{array}{l}\text { Autossômica } \\
\text { dominante }\end{array}$ & \\
\hline & & & Displasia tanatoforica tipo II & $\begin{array}{l}\text { Autossômica } \\
\text { dominante }\end{array}$ & \\
\hline Twist homolog & TWIST1 & $7 p 21$ & SCS & & \\
\hline
\end{tabular}


Drosophila 1

\begin{tabular}{|c|c|c|c|c|c|}
\hline & & & Sinostoses não sindrômicas & & \\
\hline Ephrin-B1 & EFNB1 & $\mathrm{Xq12}$ & Síndrome craniofrontonasal & Lígada ao $\mathrm{x}$ & \\
\hline $\begin{array}{l}\text { Proteína associada } \\
\text { a RAS RAB23 }\end{array}$ & $R A B 23$ & $6 p 11$ & Síndrome de Carpenter & $\begin{array}{l}\text { Autossômica } \\
\text { recessiva }\end{array}$ & \\
\hline $\begin{array}{l}\text { Muscle segment } \\
\text { homeobox } \\
\text { homolog } \\
\text { Drosophila } 2\end{array}$ & MSX2 & $5 q 34-35$ & Craniossinostose Boston type & $\begin{array}{c}\text { Autossimco } \\
\text { recessivo }\end{array}$ & \\
\hline $\begin{array}{l}\text { Transforming } \\
\text { growth factor- } \beta \\
\text { receptor type I }\end{array}$ & TGFBRI & $\begin{array}{l}9 q 33- \\
q .34\end{array}$ & Síndrome de Loeyz-Dietz & $\begin{array}{l}\text { Autossomico } \\
\text { dominante }\end{array}$ & Baixa $(<30 \%)$ \\
\hline $\begin{array}{l}\text { Transforming } \\
\text { growth factor- } \beta \\
\text { receptor type II }\end{array}$ & TGFBRII & $3 p 22$ & Síndrome de Loeyz-Dietz & & Baixa $(<30 \%)$ \\
\hline $\begin{array}{l}\text { Cytochrome p450 } \\
\text { reductase gene }\end{array}$ & POR & $7 q 11.2$ & Antley-Bixley & & $\begin{array}{l}\text { Aparentemente } \\
\text { alta }\end{array}$ \\
\hline Fibrilina & FBN1 & $15 q 21$ & $\begin{array}{l}\text { Síndrome da craniossinostose } \\
\text { Shprintzen-Goldberg }\end{array}$ & & $\begin{array}{l}\text { Muito poucos } \\
\text { casos }\end{array}$ \\
\hline
\end{tabular}

\section{Síndrome de Apert}

Daremos maior enfoque à síndrome de Apert nessa revisão pois os trabalhos a seguir se focam principalmente em estudos de células provenientes de portadores dessa síndrome.

A Síndrome de Apert (Figura I.2) é uma doença congênita caracterizada pela fusão prematura das suturas coronais, hipoplasia do terço médio da face (Figura I.3 A1, A2, B1, C1, D1, E1 e E2) e sindactilia simétrica das mãos e pés (Figura I.3 A3, B2, B3, C2, E3 e E4) tendo ao menos os dígitos 2, 3 e 4 envolvidos , (M M Cohen, 1975 OMIM \#101200). Os principais sinais clínicos são a sinostose, que é devida à fusão das suturas coronais (Figura I.3 D3), e o defeito calvarial de linha média (Figura I.3 D2), que vai desde a glabela até a fontanela posterior, sendo que as suturas sagitais e metópica não se formam. Anomalias viscerais podem estar presentes em indivíduos portadores da síndrome de Apert, entre as quais se incluem as malformações cardiovasculares (presentes em $10 \%$ dos casos) e genitourinárias $(9,6 \%)$ e anomalias no sistema respiratório (1,5\%) e gastrointestinal $(1,5 \%)$ (Cohen JR et al., 1992; M M Cohen, 1975; Mansukhani et al., 2000) . 
Wilkie et al.(1995) descobriram duas mutações no gene FGFR2 (Fibroblast Growth Factor Receptor 2) que são causativas da Síndrome de Apert: c.1028C>G (Genebank accession number M87770), resultando em p.Ser252Trp e c.1031C>G (Genebank accession number M87770), resultando em p.Pro253Arg. Estas mutações foram confirmadas para a Síndrome de Apert em outros estudos, incluindo um de autoria de nosso grupo(Lajeunie et al., 1999; Park et al., 1995; M R Passos-Bueno et al., 1998) . Outras mutações em FGFR2 associadas à Síndrome de Apert também já foram relatadas. Lajeunie et al e Oldridge et al(1999;1999). encontraram uma troca de dois nucleotídeos 755_756CG->TT que resulta em p.Ser252Phe. A raridade desta mutação é justificada por consistir na troca de dois nucleotídeos. Em 1997, nosso grupo encontrou uma mutação num sítio de aceptor de splice (940-2A->G) em um paciente com Síndrome de Apert, sendo que esta mutação é geralmente associada à Síndrome de Pfeiffer(M R Passos-Bueno et al., 1997) . 

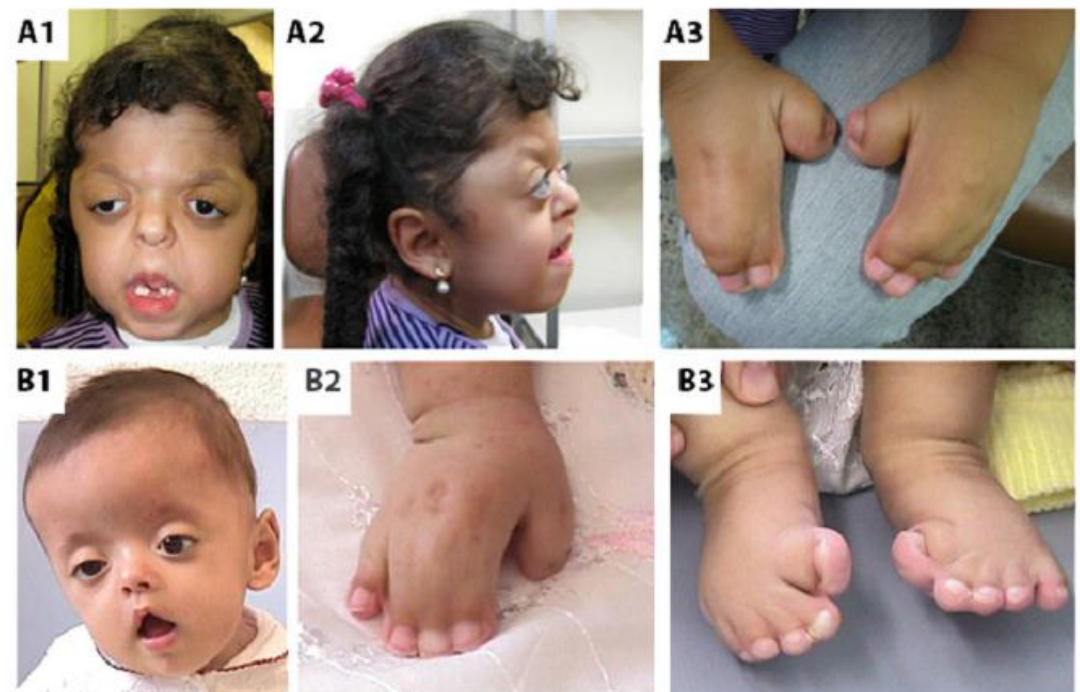

B2

4.
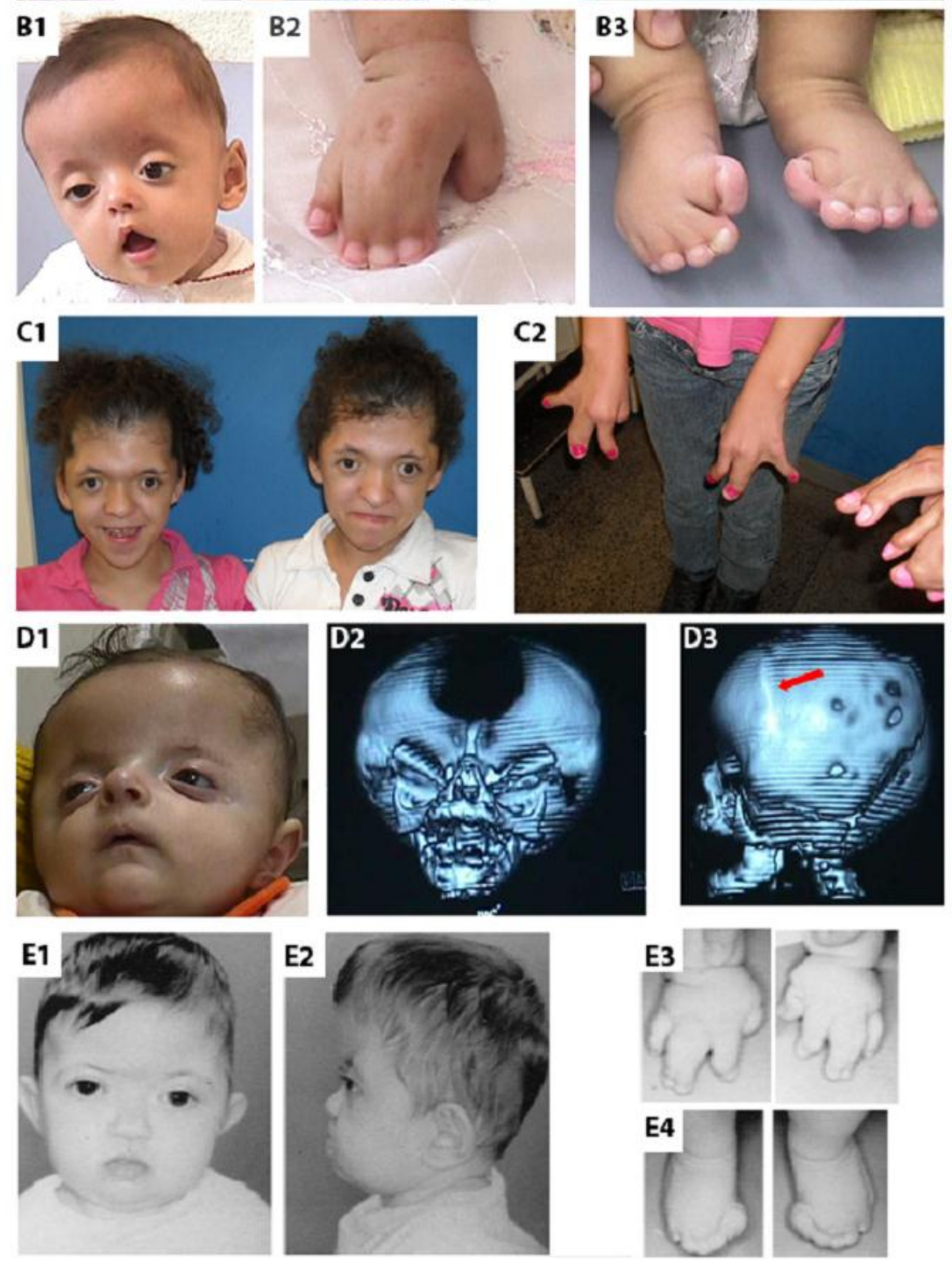

Figura I.3: Características clínicas dos pacientes de síndrome de Apert. (A) e (B) Pacientes de síndrome de Apert com a mutação S252W, apresentando características faciais típicas (A1, A2, B1) e sindactilia das mãos (A3, B2) e dos pés (B3). (C) e (D) Pacientes de síndrome de Apert com a mutação P253R, que apresentam sindactilia mais grave do que os pacientes portadores da mutação S252W (C2). Tomografia computadorizada da paciente D mostra o defeito calvarial de linha média (D2) e a fusão da sutura coronal (D3, seta vermelha). (E) Paciente com mutação atípica em sítio de aceptor de splice (c.1119-2 A>G) de FGFR2, que apresenta características faciais e defeitos de membros característicos da Síndrome de Apert. 
A prevalência da síndrome de Apert é de 1 a cada 65.000 nascidos vivos e esta síndrome representa $4 \%$ de todos os casos de craniossinostose(Cohen JR et al., 1992; Tolarova et al., 1997). O padrão de herança desta síndrome é autossômico dominante e sua razão sexual homem: mulher é de 1:1 (Cohen JR et al., 1992; Tolarova et al., 1997). Apesar de terem sido reportados 16 casos familiais de síndrome de Apert (Cohen Jr. et al., 2000), a maior parte dos casos é de mutações de novo, sendo que a origem de novas mutações é exclusivamente de origem paterna(Moloney et al., 1996) com associação etre aidade paterna (Glaser et al., 2003). Sabe-se que a mutação mais frequente associada a essa Síndrome, p.S252W em FGFR2, gera vantagem seletiva em espermatogônias humanas (Glaser et al., 2003). A raridade de casos familiais é explicada pelo reduzido valor adaptativo genético (fitness) dos indivíduos afetados, ocasionado pelas graves malformações e retardo mental associado em alguns casos, o que diminui a probabilidade desses pacientes encontrarem parceiros e deixarem descendentes (Cohen JR et al., 1992)

As mutações FGFR2 ${ }^{\text {S252W }}$ e FGFR2 ${ }^{\text {P253R }}$ são do tipo ganho de função. Ambas as mutações violam a especificidade de ligação do receptor e podem levar a ativação da sinalização das diferentes isoformas de FGFR2 por ligantes que são expressos pelo mesmo tecido (O. A. Ibrahimi, F Zhang, et al., 2004).

\section{Fatores de crescimento de fibroblasto (FGFs) e seus Receptores (FGFRs)}

Os primeiro FGFs foram descobertos pela atividade mitogênica de extratos pituitários em células 3T3 (Armelin, 1973; Gospodarowicz, 1974). Desde então 22 diferentes FGFS foram identificados em uma grande variedade de animais que abrangem desde nematódeos e drosophilas até humanos e camundongos (David M Ornitz et al., 2001). Apesar dos FGFs variarem em tamanho de 17 a 34 Kda, 
todos os membros da família compartilham uma sequencia de 120 aminoácidos que apresenta uma homologia de $16-65 \%$. FGFs mediam várias respostas celulares durante a embriogênese e no indivíduo adulto. Durante o desenvolvimento embrionário, FGFs desempenham um papel fundamental na morfogênese regulando a proliferação, diferenciação e migração celular. Nos organismos adultos, FGFs desempenham um papel importante no controle do sistema nervoso, reparo tecidual, fechamento de feridas e angiogênese tumoral (Givol, 1992).FGFs desempenham sua resposta celular ao se ligar e ativar os membros da família de quatro receptores tirosino quinase FGFRs. Há ainda um quinto FGFR, conhecido como FGFR5 ou FGFRL1 (FGFR-like 1), que pode se ligar a FGFs, mas não apresenta domínio tirosino-quinase, e para o qual foi proposto a função de regulador negativo da sinalização FGF(Trueb et al., 2003).

Como todos os receptores tirosino-quinase, os 4 FGFRs (FGFR1-4) são compostos por um domínio extra-celular responsável pela ligação com seus ligantes, um único domínio transmembrana e uma porção citoplasmática que contém o sítio catalítico tirosino-quinase, além de várias sequências regulatórias(Figura I.3). (Lemmon et al., 2010). O domínio extracelular dos FGFRs é composto por três alças immunoglobulin (Ig) like designadas Ig-I a Ig-III; e a característica considerada a marca registrada dos FGFRs :um fragmento de sete a oito resíduos ácidos entre as alças Ig-I e Ig-II chamado de acid box (caixa ácida) e uma região carregada positivamente em Ig-Il que serve como sítio de ligação para heparina (J Schlessinger et al., 2000). 


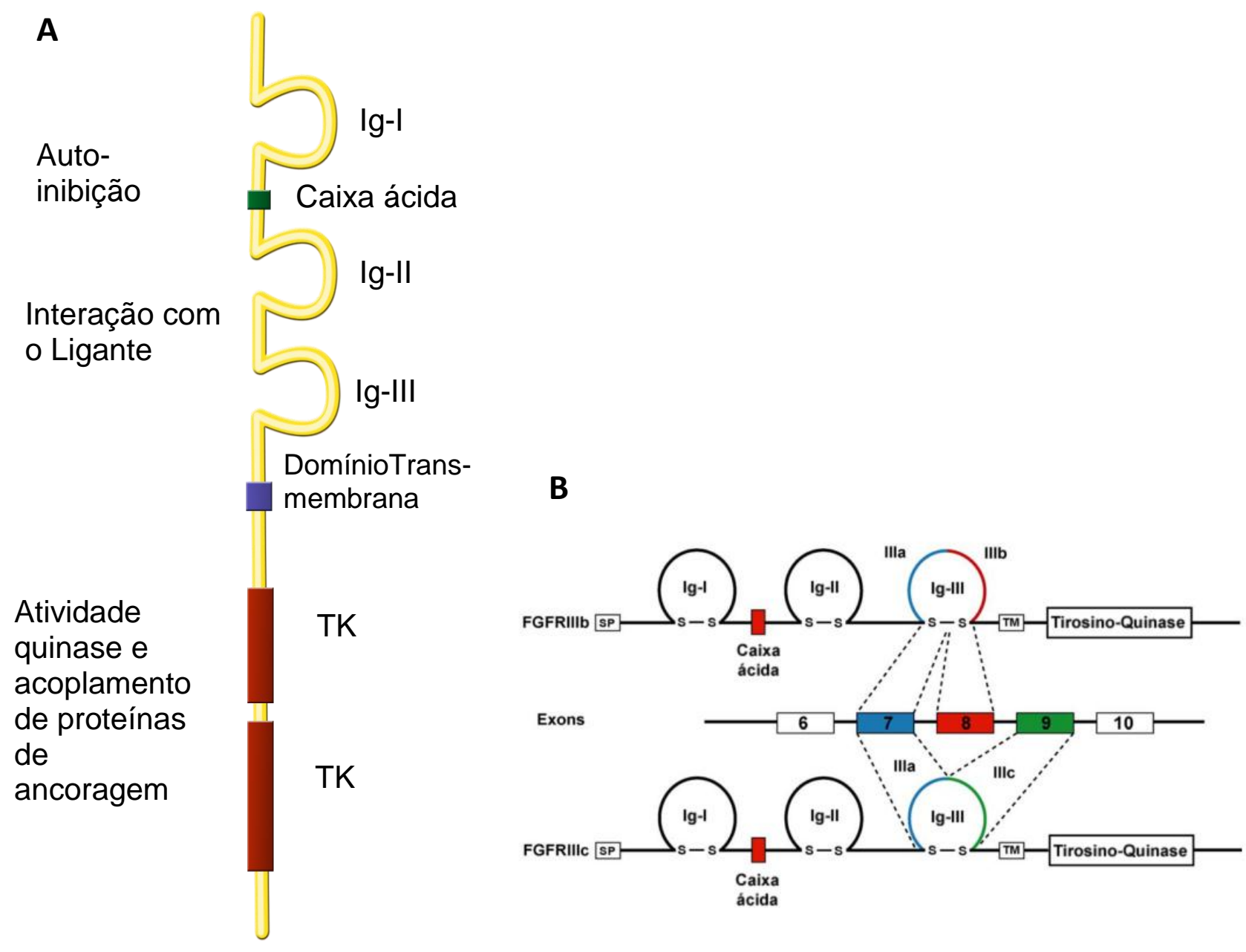

Figura I.4: A - Estrutura dos FGFRs. Os FGFRs são compostos, na região extracelular, por 3 alças Ig-like (Ig I, II e III), um domínio transmembrana único, e, na região intracelular, por 2 domínios tirosino-quinase (TK1 e TK2). Entre as alças Ig-I e Ig-Il existe uma região de auto-inibição do receptor chamada caixa ácida. A região de especificidade do ligante se localiza na alça Ig-III. A ativação das vias de transdução de sinal ocorre pelos domínios Tirosino-Quinase. B - Splicing alternativo entre diferentes isoformas de FGFRs, no caso de FGFR2, a alça Ig-III é codificada por 2 exons, a porção $\mathrm{N}$-terminal é codificada pelo exon 7,e a metade C-terminal pode ser codificada pelos exons 8 e 9, sendo que a isoforma FGFR2b é codificadas pelo exon 8 e a isoforma FGFR2c é codificada pelo exon 9.

A transcrição de genes que codificam três dos FGFRs (FGFR1, 2 e 3) resulta na expressão de várias isoformas dos receptores devido à ocorrência de processamentos alternativos, o que determina o número de domínios Ig-like (dois ou três domínios) e, mais importante, splicing alternativo dos exons que codificam a região C-terminal do domínio IgIII. Este processamento alternativo aumenta o grau de diversidade molecular, uma vez que expande as propriedades de ligação do receptor a diferentes FGFs 
(Givol, 1992; D M Ornitz, 2000). O splicing alternativo é tecido-específico e produz a isoforma "c" (ex.: FGFR1c, FGFR2c e FGFR3c), cuja alça Ig-Ill é codificada pelos exons Illa e Illc (exons 8 e 10 em camundongos; 9 e 11 em humanos), a mais abundante e expressa em tecidos de origem mesenquimal; e $a$ isoforma "b" (ex.: FGFR1b, FGFR2b e FGFR3b), cuja alça Ig-III é codificada pelos exons IIla e IIIb (exons 8 e 9 em camundongos; 9 e 10 em humanos) menos frequente e expressa em tecidos de origem epitelial(Chellaiah et al., 1994; Miki et al., 1992; Naski et al., 1998; Orr-Urtreger et al., 1993). As propriedades de ligação de cada isoforma são bastante específicas (Tabela I. 3).

Tabela I.3: Especificidade de ligação entre FGFRs e FGFs

\begin{tabular}{|l|l|}
\hline Isoforma de FGFR & Ligantes Específicos \\
\hline FGFR1b & FGF1, 2, 3 e 10 \\
\hline FGFR1c & FGF1, 2, 4, 5 e 6 \\
\hline FGFR2b & FGF1, 3, 7 10 e 22 \\
\hline FGFR2c & FGF1, 2, 4, 6, 9, 17 e 18 \\
\hline FGFR3b & FGF1 e 9 \\
\hline FGFR3c & FGF1, 2, 4, 8, 9, 17, 18 e 23 \\
\hline FGFR4 & FGF1, 2, 4, 6, 8, 9, 16, 17, 18 e 19 \\
\hline
\end{tabular}




\section{Vias de Sinalização reguladas por FGFR2}

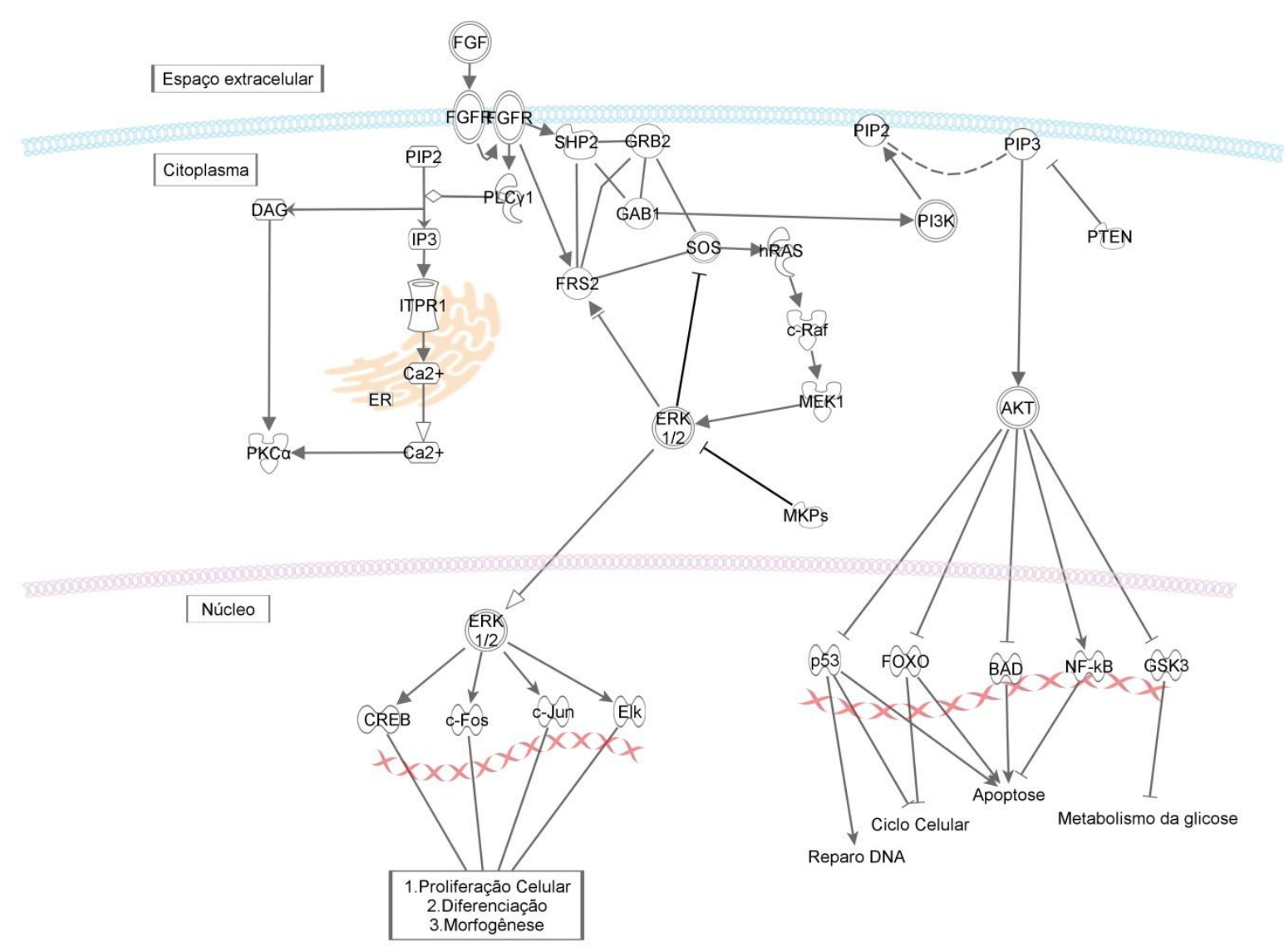

(๑) 2000-2011 Ingenuity Systems, Inc. All rights reserved.

Figura 1.5 : Vias de sinalização ativadas por FGFRs, adaptado de CHALHOUB; BAKER, 2009,KRISHNA; NARANG, 2008, LEMMON; SCHLESSINGER, JOSEPH, 2010 e Banco de dados Ingenuity Pathways.

Quando ligado a um de seus ligantes, os FGFRs desencadeiam vias de sinalização associadas à apoptose, sobrevivência e proliferação celular(Eswarakumar et al., 2005)(Figura I.5). Os FGFs presentes no meio extracelular se ligam a moléculas de heparina ou heparan-sulfato, isso aumenta a afinidade dessas duas moleculas pelos FGFRs (O. Ibrahimi, Fuming Zhang, et al., 2004). O complexo FGFR+FGF+Heparina tende a formar homodímeros, nos quais o heparan e os FGFs aproximam os 
domínios D2 e D3 de ambos os FGFRs, o que inicia a etapa de autofosforilação do domínio Tirosinoquinase do dímero de receptores (Eswarakumar et al., 2005). A autofosforilação do domínio tirosinoquinase ocorre em trans, em 3 fases distintas, o substrato chave de fosforilação da primeira fase é pY653, localizado na alça de ativação, uma sequência específica o que aumenta a atividade tirosinoquinase do receptor em 10-50 vezes. A segunda fase ocorre em uma ordem inesperadamente precisa (pY583, pY463 e pY583/pY585), essas 3 tirosinas são provavelmente sítios de ligação de SH2 e PTB e sua fosforilação está associada ao recrutamento de moléculas de sinalização downstream. A terceira fase de autofosforilação ocorre na tirosina 654 e aumenta em mais 10 vezes a atividade catalítica do domínio tirosino quinase de FGFRs por FRS2 $\alpha$ (Substrato do Receptor de Fator de Crescimento de Fibroblasto 2) e PLCY (Fosfolipase C) (Furdui et al., 2006). A região transmembrana dos receptores FGFR contém uma sequência altamente conservada que serve como sítio de ligação do domínio de ligação de fosfotirosina (PTB) de dois membros da família FRS2: FRS2 $\alpha$ e FRS2 $\beta$. A tirosina Y766 na região carboxi-terminal dos FGFRs, quando fosforilada, cria uma região específica de ligação para o domínio SH2 de PLC (Eswarakumar et al., 2005).

\section{MEK/ERK}

O recrutamento e fosforilação em múltiplas tirosinas de FRS2 $\alpha$ por FGFR leva ao recrutamento de múltiplas moléculas de Grb2 e Shp2, o que leva ao acoplamento de uma segunda proteína de ancoragem Gab1 ao complexo e a ativação de SOS (Son of Sevenless), ativando assim Raf e Ras, os primeiros níveis da via MEK/ERK. (Lemmon et al., 2010)

ERK foi a primeira MAPK a ser descoberta e é a MAPK mais bem estudada. A cascata de sinalização MEK/ERK é ativada por vários estímulos extracelulares e intracelulares. A via MEK/ERK é ativada fortemente por fatores de crescimento, soro, ésteres de forbol, e, mais fracamente, por ligantes de GPCRs, citocinas, estresse osmótico e desorganização dos microtúbulos. 
A sinalização dessa via é geralmente iniciada pela ativação de receptores de membrana. 0 sinal é então transduzido para pequenas proteínas G (e.g., Ras), que transmitem o sinal ao recrutar a camada MAP3K (MAPKKK), por exemplo Raf quinases, para a membrana plasmática, onde podem ser ativadas. Outros componentes das MAP3K podem ativar MEK/ERK sob condições específicas c-Mos, TPL2 e MEKK 1/2/3, que agem principalmente durante a meiose, proliferação e resposta ao estresse, respectivamente. Raf (ou outras MAP3Ks), quando ativo, se liga e fosforila as MAP2Ks MEK1 e 2, as quais fosforilam ERK1/2 em um motivo Thr-Glu-Tyr conservado em sua alça de ativação(Krishna et al., 2008).

Uma vez fosforilados, ERKs fosforilam vários outros substratos. Algumas dessas moléculas estão localizadas no citoplasma e outras estão no núcleo, cuja fosforilação depende da translocação de ERK para o núcleo. ERK fosforila e ativa uma série de fatores de transcrição, como Elk1, c-Fos, p53, Ets1/2 e até mesmo c-Jun, que são importantes na regulação dos processos de proliferação, diferenciação e morfogênese (Shaul et al., 2007).

\section{PI3-K}

O recrutamento e ativação de Grb2 e Shp2 podem levara ao recrutamento de outra proteína de ancoragem ao complexo, Gab1. Gab1 é fosforilada e recruta outras moléculas de sinalização, dentre elas PI3-K(Eswarakumar et al., 2005) .PI3-K (fosfatidilinositol 3-quinase) fosforila o anel inositol em fosfatidilinositol na posição 3',e já foi descrito como envolvido na transdução de sinal da maior parte, senão todos os receptores tirosino-quinase. (Klint et al., 1999).

A via PI3-K é evolutivamente conservada, e regula diversos processos celulares desde mamíferos até leveduras. Em eucariotos superiores a via PI3-K regula processos como: metabolismo, sobrevivência, proliferação, apoptose e crescimento.

PI3-K é recrutado por receptores tirosino-quinase, levando ao aumento dos níveis de fosfatidilositol-3,4,5-trisfosfato (PIP3). PIP3 recruta muitas proteínas à membrana plasmátca ligando-as 
a seu domínio PH (Pleckstrin Homology), dentre estas, as serina/treonina quinases AKT, PDK1 e PHLPP. AKT é ativado por fosforilação, isso é feito pelas moléculas PDK1 e pelo complexo do alvo da rapamicina em mamíferos (mTOR) insensível à rapamicina (mTORC2), e desativado quando desfosforilado por PHLPP.

AKT ativado pode fosforilar diversos substratos, os ativando ou inibindo e, por consequência, levando a efeitos celulares como crescimento, sobrevivência e proliferação por diversos mecanismos. PI3-K também pode regular outros alvos independentemente de AKT, como RAC1 e CDC42. Inibição de mTORC1 também pode ocorrer pois AKT regula a atividade de TSC1 e TSC2 ( complexo da esclerose tuberosa), que por sua vez regulam mTORC1(Chalhoub et al., 2009).

\section{PLC}

Alternativamente, a autofosforilação de FGFR pode levar a ligação do domínio SH2 N-terminal de PLC.

As enzimas PLC, encontradas em eucariotos, compreendem um grupo de proteínas que clivam a cabeça polar de fosfatidilinositol 4,5-bisfosfato (PIP2). A clivagem desse fosfolipídio e a geração de dois segundos mensageiros: inositol 1,4,5-trisfosfato (IP3), um mensageiro universal de mobilização de cálcio, e Diacilglicerol (DAG), um ativador de diversos tipos de proteínas, incluindo isoformas da proteína quinase C (PKC). Esses segundo mensageiros promovem um elo comum para hormônios específicos, neurotransmissores, antígenos, componentes da membrana extracelular e fatores de crescimento. Dessa maneira eles contribuem para a regulação de diversas funções biológicas: motilidade celular, fertilização, transdução sensorial, entre outros. Além de seu papel como substrato de PLC, PIP2 têm outras funções e mudanças na sua concentração afeta processos celulares. Um papel importante de diferentes fosfoinositideos é a indicação de proteínas para compartimentos celulares específicos, com grande importância para movimentos de membrana e movimento celular (Bunney et al., 2011). 


\section{Modelos celulares da síndrome de Apert}

O estudo funcional da síndrome de Apert se baseia principalmente em modelos animais, com 3 modelos já bem estabelecidos (L. Chen, 2003; Holmes et al., 2009; Y. Wang et al., 2002) e em modelos celulares. Os modelos animais, apesar de sua grande importância para o esclarecimento da etiologia dessa doença apresentam contradições em certos aspectos, como proliferação celular na sutura, aumento de marcadores osteogênicos e idade da fusão da sutura coronal. Isso demonstra a importância de modelos alternativos para o estudo dessa síndrome, como os modelos celulares.

Os osteoblastos presentes na sutura afetada pela síndrome de Apert foram, e ainda são, o principal modelo celular para os estudos funcionais da S. de Apert, uma vez que eles são comumente vistos como os responsáveis pelo fechamento precoce da sutura coronal, no entanto os achados pelos diversos estudos são contraditórios.

A transfecção de osteoblastos calvariais murinos com FGFR2 ${ }^{\mathrm{S252W}}$ inibiu a diferenciação e induziu a apoptose (Mansukhani et al., 2000). Por sua vez, a transfecção de osteoblastos calvariais de galinha com FGFR2 ${ }^{\text {P253R }}$ mostrou fraco efeito mitogênico e não alterou a mineralização durante a diferenciação osteogênica (Fakhry et al., 2005). Osteoblastos isolados de ossos longos do modelo murino de Wang et al. (Y. Wang et al., 2002) apresentaram aumento da proliferação e diferenciação, bem como respostas alteradas dessas funções celulares na presença de FGF2 ou FGF10(F. Yang et al., 2008) . Como neste último estudo, células mesenquimais C3H10T1/2 transfectadas com FGFR2 ${ }^{\mathrm{S} 252 \mathrm{~W}}$ também apresentaram aumento na proliferação, que foi diminuído ao se inibir a via ERK, e na diferenciação osteogênica, que também se reduziu ao inibir a via da PKC (Miraoui et al., 2009). 
Para avaliar a influência da dura-máter sobre os osteoblastos da sutura, Ang e colaboradores utilizaram o sistema de co-cultura, no qual células da dura-máter de camundongos são cultivadas sobre membranas com poros pequenos o suficiente para impedir a passagem de células e organelas, mas que permitam a passagem de moléculas sinalizadoras para o nível abaixo, onde os osteoblastos murinos são cultivados. As células da dura-máter transfectadas com FGFR2 ${ }^{\mathrm{P} 253 \mathrm{R}}$ acentuaram a diferenciação óssea de osteoblastos selvagens, evidenciando a importância da mutação Apert na dura-máter no processo de osteogênese de tecidos adjacentes (Ang et al., 2010)

\section{Participação do periósteo na patofisiologia da Síndrome de Apert}

O complexo das suturas permitem regular o balanço entre proliferação e diferenciação de precursores osteogênicos (Slater et al., 2008). Notavelmente, muitos estudos têm apontado a importância do periósteo na formação óssea do crânio. O periósteo contribui não só para o crescimento normal do osso, mas também para a consolidação e regeneração óssea (Ito et al., 2001) e é altamente celular, contendo de células-tronco, fibroblastos, células osteoprogenitoras diferenciadas até osteoblastos (Allen et al., 2004; Squier et al., 1990). Em ossos longos, o periósteo é uma importante fonte de células-tronco esqueléticas/progenitoras durante a reparação óssea (Colnot, 2009) .No entanto, como os diferentes tipos celulares do periósteo da calvária interagem e como esse tecido atua em uma situação patológica, como a alteração de sinalização FGF levando a craniossinostose, ainda é desconhecida.

Os fibroblastos de periósteo portadores da mutação FGFR2 ${ }^{\mathrm{P} 253 \mathrm{R}}$ apresentaram expressão aumentada de proteoglicanas envolvidas na fibrilogênese de colágeno que diminuía perante a 
administração de FGF2(Lilli et al., 2007) .Os autores sugerem que as alterações na matriz poderiam influenciar na ligação de FGFs ao FGFR2, apesar de eles não terem investigado isso.

Estudos anteriores do nosso grupo compararam o perfil de expressão gênica de fibroblastos provenientes do periósteo da região da sutura coronal de pacientes portadores da S. de Apert e de Controles(R.D. Fanganiello et al., 2007). Nesse estudo foram encontrados 263 genes diferencialmente expressos, sendo que as categorias funcionais mais enriquecidas foram: Regulação do ciclo celular, apoptose, regulação da expressão gênica, adesão celular e genes da via MAPK.

Um dos genes diferencialmente expressos e considerado como funcionalmente relevante encontrados nesse estudo foi DUSP2 (2.25 vezes mais expressa em Fibroblastos de pacientes do que em controles). DUSP2 é uma fosfatase dupla específica (Dual specific phosphatase), um grupo grande e heterogêneo caracterizado pela sua capacidade de desfosforilar seu substrato em 2 resíduos (Tirosina e Serina/Treonina). DUSP2 é também um membro do subgrupo mais bem caracterizado dentre as DUSPs, as MKPs (fosfatases de proteínas-quinases ativadas por mitógenos).Esse subgrupo contém 10 proteínas que desfosforilam MAPKs em seus resíduos fosfo-treonina e fosfo-tirosina simultaneamente no motivo TXY( Thr-Xaa-Tyr) característico das MAPKs, atuando como antagonistas dessa via de sinalização (Patterson et al., 2009).

A importância dessa classe de proteínas para as craniossinostoses foi demonstrada em experimentos em modelos in vivo, nos quais o camundongo modelo nocaute de DUSP6 (outra DUSP pertencente às MKPs) apresenta sinostose coronal(Chaoying Li et al., 2007).

Estudos in vitro demonstraram que DUSP2 age como reguladora negativa da atividade de quinases N-terminais de c-Jun (JNKs)(Jeffrey et al., 2006). JNKs, originalmente nomeadas proteínas quinase ativadas por estresse (SAPKs), foram renomeadas para enfatizar seu papel na fosforilação do 
fator de transcrição c-Jun. Os JNKs são ativados fortemente em resposta à citocinas, radiação UV, privação de fatores de crescimento, dano ao DNA; e de maneira mais branda por estímulo de GPCRs, presença de soro e fatores de crescimento (Krishna et al., 2008). JNK também se mostrou importante no processo de ossificação por sua forma ativa (fosforilada) p-JNK ser capaz de modular a resposta de préosteoblastos a BMP2(H. Liu et al., 2010).

Fanganiello et al., 2007 observaram aumento de diferenciação osteogênica em culturas de fibroblastos de periósteo derivados de pacientes com síndrome de Apert, no entanto ainda não se sabe qual via de sinalização intracelular é responsável por essa alteração de fenótipo. A delimitação de qual via é responsável por esse aumento de diferenciação é de vital importância na descoberta de drogas para o tratamento da S. de Apert, principalmente drogas que sejam capazes de diminuir o processo de ressinostose, o que reduziria o número deintervenções cirurgicas e a morbidade associada à síndrome.

\section{Questões não respondidas}

O único tratamento disponível para estes pacientes é a correção cirúrgica, que por sua vez é considerada como apenas um atraso no processo de sinostose. Assim sendo, uma melhor compreensão do processo de regeneração óssea nesses pacientes poderá resultar em benefícios para melhores condutas terapêuticas destes.

Como detalhamos previamente, o complexo das suturas permitem regular o balanço entre proliferação e diferenciação de precursores osteogênicos (Slater et al., 2008). Notavelmente, muitos estudos têm apontado a importância do periósteo na formação óssea. O periósteo contribui não só para o crescimento normal do osso, mas também para a consolidação e regeneração óssea (Ito et al., 2001, 
Orwoll, 2006). No entanto, como os diferentes tipos celulares do periósteo da calvária interagem e como esse tecido atua em uma situação patológica, como a alteração de sinalização FGF levando a craniossinostose, ainda é desconhecida.

Até hoje os estudos sobre sinalização na síndrome de Apert se concentraram em explorar o papel da via MEK/ERK na patofisiologia da síndrome (Shukla et al., 2007), o que é justificado pelo fato dessa via já ter sido descrita diversas vezes como reguladora da diferenciação celular (Eswarakumar et al., 2005; Krishna et al., 2008). A via PI3-K geralmente tem sua importância menosprezada na participação da determinação do fenótipo da S. de Apert. Essa via é geralmente descrita como mediadora da morte celular programada já que ela regula diversos fatores de transcrição associados à apoptose como a família FOXO, BIM, p53 entre outros (Chalhoub et al., 2009). Outro motivo pelo qual os estudos tendem a ignorar essa via é que os FGFRs não são tão eficientes em recrutar PI3-K como outros receptores tirosino-quinase (e.g. PDGFR). No entanto ainda não se sabe exatamente como as duas vias interagem e regulam fatores importantes para a determinação do fenótipo da S. de Apert.

Outra questão em aberto é como a mutação p. S252W em FGFR2 leva à alterações da expressão de DUSP2 e como essa fosfatase pode estar associada à S. de Apert.

\section{Objetivos}

Nossa hipótese é que o periósteo contribui para o processo acelerado (ou atípico) de fusão, prematura e pós-cirúrgica, das suturas coronais na Síndrome de Apert, não só como fonte de moléculas de sinalização, mas também de células osteoprogenitoras. Caso isso seja verdade estas células devem 
ter alterações em funções celulares como proliferação, migração e diferenciação, além de alterações nas vias de sinalização intracelulares que poderiam resultar nesses fenótipos celulares alterados.

Para testar esta hipótese, nós traçamos dois objetivos principais:

I) Verificar se a mutação p.S252W, a mais frequente entre os pacientes com Síndrome de Apert, tem um efeito funcional/celular semelhante em duas diferentes potenciais células osteoprogenitoras: fibroblasto e células-tronco mesenquimais (Esse objetivo também foi parte da tese de Doutorado da Dra. Erika Yeh);

II) Verificar quais das vias celulares associadas à FGFR2 está associada ao aumento de expressão de DUSP2 nessas células e o efeito desse aumento sobre os níveis de fosforilação de JNK.

Para respondermos ao primeiro objetivo desenvolvemos os objetivos específicos:

I.a) Verificar o efeito da mutação S252W na proliferação, migração em fibroblastos e células-tronco mesenquimais (MSCs) provenientes do periósteo de suturas coronais;

I.b) Corroborar que fibroblastos com a mutação S252W têm maior potencial osteogênico (resultado inicialmente publicado pelo nosso grupo (R.D. Fanganiello et al., 2007);

I.c) Verificar se a mutação S252W interfere na indução osteogênica de MSCs provenientes de periósteo.

Para respondermos a segunda questão desenvolvemos os seguintes objetivos específicos: 
II.a) Verificar se existe diferença na fosforilação de JNK em fibroblastos de periósteo de pacientes com S. de Apert.

II.b) Verificar se a regulação das vias MEK/ERK e PI3-K está sendo alterada pela mutação p.S252W em FGFR2.

II.c) Verificar se os níveis proteicos de DUSP2 está sendo regulado pelas vias ativadas por FGFR2 e se essa diferença se traduz em níveis diferentes de fosforilação de JNK. 


\section{Capítulo II}

\section{FGFR2 MUTATION CONFERS A LESS DRASTIC GAIN OF FUNCTION IN MESENCHYMAL STEM CELLS THAN IN FIBROBLASTS}

Manuscrito aceito na revista "Stem Cell Reviews and Reports"

Erika Yeh

Rodrigo Atique

Felipe Augusto André Ishiy

Roberto Dalto Fanganiello

Nivaldo Alonso

Hamilton Matsushita

Katia Maria da Rocha

Maria Rita Passos-Bueno 


\section{Abstract}

Gain-of-function mutations in FGFR2 cause Apert syndrome (AS), a disease characterized by craniosynostosis and limb bone defects are due to abnormalities in bone differentiation and remodeling. Although the periosteum is an important cell source for bone remodeling, its role in craniosynostosis remains poorly characterized. We hypothesized that periosteal mesenchymal stem cells (MSCs) and fibroblasts from AS patients have abnormal cell phenotypes that contribute to the recurrent fusion of the coronal sutures. MSCs and fibroblasts were obtained from the periostea of 3 AS patients (S252W) and 3 control individuals (WT). We evaluated the proliferation, migration, and osteogenic differentiation of these cells. Interestingly, S252W mutation had opposite effects on different cell types: S252W MSCs proliferated less than WT MSCs, while S252W fibroblasts proliferated more than WT fibroblasts. Under restrictive media conditions, only S252W fibroblasts showed enhanced migration. The presence of S252W mutation increased in vitro and in vivo osteogenic differentiation in both studied cell types, though the difference compared to WT cells was more pronounced in S252W fibroblasts. This osteogenic differentiation was reversed through inhibition of JNK. We demonstrated that S252W fibroblasts can induce osteogenic differentiation in periosteal MSCs but not in MSCs from another tissue. MSCs and fibroblasts responded differently to the pathogenic effects of the FGFR2 ${ }^{\mathrm{S} 252 \mathrm{~W}}$ mutation. We propose that cells from the periosteum have a more important role in the premature fusion of cranial sutures than previously thought and that molecules in JNK pathway are strong candidates for the treatment of AS patients. 


\section{Resumo}

Mutações do tipo ganho de função em FGFR2 causam a síndrome de Apert, uma doença caracterizada por craniossinostose e defeitos ósseos nos membros devidos a anormalidades na diferenciação e remodelamento ósseos. Apesar do periósteo ser uma importante fonte de células durante o remodelamento ósseo, seu papel nas craniossinostoses ainda é pouco conhecido. Nossa hipótese é que as células tronco mesenquimais (MSCs) e fibroblastos de pacientes com S. de Apert tem fenótipos celulares alterados que contribuem para o fechamento recorrente das suturas coronais. MSCs e fibroblastos foram obtidos do periósteo de 3 pacientes portadores da S. de Apert (S252W) e 3 indivíduos controles (WT). Nós analisamos a proliferação, migração e diferenciação osteogênica dessas células. Surpreendentemente, a mutação S252W teve efeitos opostos em tipos celulares diferentes: MSCs S252W proliferaram menos que as S252W controle, enquanto fibroblastos S252W proliferaram mais que fibroblastos controle. Somente os fibroblastos S252W mostraram aumento na migração celular. A presença da mutação $\mathrm{S} 252 \mathrm{~W}$ aumentou a diferenciação osteogênica in vitro e in vivo em ambos os tipos celulares estudados, no entanto a diferença em relação aos controles foi maior em fibroblastos S252W. Esse aumento de diferenciação osteogênica foi revertido pela inibição de JNK. Nós demonstramos que fibroblastos S252W podem induzir a diferenciação osteogênica em MSCs de periósteo, porém não em MSCs de outras fontes. MSCs e fibroblastos responderam diferentemente aos

efeitos patogênicos da mutação FGFR2 ${ }^{\mathrm{S252W}}$. Nós propomos que células do periósteo tem um papel mais importante no fechamento precoce das suturas cranianas do que se imaginava anteriormente e que moléculas da via JNK são fortes candidatas para o tratamento de pacientes da S. de Apert. 


\section{Introduction}

Apert Syndrome (AS), the most severe form of craniosynostosis (Cohen Jr. et al., 2000), is characterized by premature fusion of the coronal sutures, severe syndactyly of the hands and feet and by a range of skeletal abnormalities, including progressive joint limitation (McHugh et al., 2007)This autosomal dominant syndrome is caused by gain-of-function mutations in the FGFR2 gene. The most prevalent mutation, accounting for approximately $65 \%$ of all AS cases, is S252W. FGFR2, by means of alternative mRNA splicing, can be transcribed into an epithelial and a mesenchymal isoform. Both isoforms are tyrosine kinase receptors that bind to a specific subset of fibroblast growth factors (FGFs) to induce a variety of cell functions, such as cell migration, proliferation, and differentiation (D M Ornitz, 2000). In the presence of the S252W mutation, FGFR2 shows enhanced ligand-binding affinity to FGF2 and loses isoform-ligand specificity for most of the other ligands(O. A. Ibrahimi, F Zhang, et al., 2004). This mutation affects both the epithelial and the mesenchymal FGFR2 isoforms. Although most of the clinical features of AS arise as a consequence of signaling disturbance during embryonic development, FGFR2S252W also interferes in post-natal organism homeostasis. Surgical opening of the coronal sutures is a mandatory procedure for AS patients. However, the excessive and repetitive closure of these sutures after the procedure (resynostosis) requires multiple interventions from birth until adulthood(Cohen Jr. et al., 2000).

It has been postulated that FGFR2 ${ }^{\mathrm{S252W}}$ enhances cell proliferation, which would account for the higher ossification rate at the sutures(Beenken et al., 2009). However, we still do not know if this enhanced proliferation is observed in all cell types. Most studies have focused on murine osteoblasts 
harboring the AS mutation, but both increased (F. Yang et al., 2008)and decreased (Lomri et al., 1998)proliferation have been observed. Studies on the effect of FGFR2S252W on osteogenic potential have also produced contradictory results (Lomri et al., 1998; Mansukhani et al., 2000; F. Yang et al., 2008). Few studies have investigated the functional effect of FGFR2 $2^{5252 \mathrm{~W}}$ in human cells, which are considerably different from murine cells in regard to cell signaling (Bulfield, 1984; Dhillon et al., 2010; Haley, 2003; Harries et al., 2009; Mestas et al., 2004). We have conducted a preliminary study in which we suggested that S252W fibroblasts have an increased osteogenic potential (R.D. Fanganiello et al., 2007), a finding that we sought to replicate using in vivo models. On the other hand, there are no studies on human AS mesenchymal stem cells (MSC), the possible precursors of osteoblasts. The premature suture fusion and the resynostosis process after surgical interventions are not likely the result of alterations in one particular cell type, such as osteoblasts, but the result of perturbations in signaling and in interactions between different cell types and tissues of the cranial suture complex (Slater et al., 2008).

The cranial suture complex comprises the overlying periosteum of the calvaria, the osteogenic fronts of the bone plates, the intervening mesenchyme, and the underlying dura mater. This complex allows skull deformation during birth, expansion during brain growth and regulates the balance between proliferation and differentiation of osteogenic precursors(Slater et al., 2008). Several studies have indicated dura mater as a crucial tissue that regulates suture patency, so it is assumed that signaling by this tissue is deregulated in AS patients, contributing to premature embryonic synostosis as well as adult resynostosis (Cohen Jr. et al., 2000; Foster et al., 2008). Remarkably, the removal of the periosteum diminishes calcification of cranial defects in animal models (Ozerdem et al., 2003), which highlights the importance of the periosteum in cranial bone formation. The periosteum contributes not only to normal bone growth, but also to bone healing and regeneration (Hosoi, 2010; Ito et al., 2001). This highly cellular tissue contains multipotent MSC, fibroblasts, differentiated osteogenic progenitor cells and 
osteoblasts (Allen et al., 2004; Squier et al., 1990), and acts as a major source of skeletal stem cells/progenitors during bone repair(Colnot, 2009). It is thus possible that periosteal cells also have a major contribution to the premature suture fusion in AS patients; however, their role in this process is still poorly characterized. In addition, it is still unknown how the different cell types from the calvarial periosteum interact and what is the functional effect of the FGFR2 $2^{5252 \mathrm{~W}}$ mutation in these cells. JNK (cJun $\mathrm{N}$-terminal kinases) has been reported as crucial for the final stage of differentiation in preosteoblasts and pluripotent cells (Bullaughey et al., 2009; H. Liu et al., 2010; Matsuguchi et al., 2009), and is considered a critical regulator of important osteogenic differentiation markers (Guicheux et al., 2003; Matsuguchi et al., 2009). In addition, two negative regulators of JNK activity of the same family are associated with craniosynostosis: DUSP6 and DUSP2. The loss of Dusp6 leads to coronal craniosynostosis in mice (Chaoying Li et al., 2007), and we have previously reported that DUSP2 was one of the most significant differentially expressed genes in AS periosteal cells(R.D. Fanganiello et al., 2007) .Therefore, JNK is an interesting candidate for the altered osteogenic potential of S252W cells.

In view of the above, we conducted this study to access the effect of the FGFR2 $2^{5252 \mathrm{~W}}$ mutation in fibroblasts and MSCs derived from the coronal periosteum. We examined these cells' proliferative capacity, motility, and osteogenic potential and also evaluated whether there is a functional interaction between them. Finally, we have evaluated the role of JNK in the increased osteogenic potential of S252W fibroblasts.

\section{Materials and Methods}




\section{Subjects}

Coronal suture periosteal fibroblasts and MSCs from three unrelated AS patients and from three age- and sex-matched control subjects were obtained as previously described (R.D. Fanganiello et al., 2007). The presence of the c.934G>C (p.S252W) mutation was confirmed by direct DNA sequencing and expression of the mesenchyme-specific isoform of FGFR2 in the primary fibroblasts was examined by Western Blot and RT-PCR (R.D. Fanganiello et al., 2007).

\section{Cell Culture}

Periostea harvested from AS patients or control individuals were split in half for fibroblast and MSC extraction. Primary periosteal fibroblasts derived from periosteal flaps were grown in fibroblast growth medium (DMEM High-Glucose, 20\% fetal bovine serum [FBS; GIBCO] and $100 \mathrm{U} / \mathrm{mL}$ penicillin and $100 \mu \mathrm{g} / \mathrm{mL}$ streptomycin [1\% Penicillin Streptomycin; GIBCO]). Cells were passaged at near confluency with trypsin-EDTA. MSC cultures were obtained from finely minced periosteum after 30 minutes of trypsin incubation and grown in MSC growth medium (DMEM-F12 [Invitrogen] supplemented with 15\% FBS [GIBCO] and 1\% Penicillin Streptomycin [GIBCO]). All cells were cultured in a humidified incubator at $37{ }^{\circ} \mathrm{C}$ and $5 \% \mathrm{CO} 2$. All tests were performed between the third and the fifth subcultures.

For each of the 12 cell lines (three S252W fibroblasts, three WT fibroblasts, three S252W MSCs and three WT MSCs), we performed experiments in technical triplicates. For all the experiments, we used all twelve cell lines for each condition, the exceptions are indicated by an " $n$ " value. Thus we tried to ensure that the results we obtained were representative of the biological variance seen in human patients. 


\section{Immunophenotyping}

To analyze cell-surface expression of typical protein markers, adherent cells were incubated with the following anti-human primary antibodies: CD29-PECy5, CD31-phycoerythrin(PE), CD45fluorescein isothiocyanate (FITC), CD90-R-PE, CD117-PE, and SH3 (Becton Dickinson). A total of 5,000 labeled cells were analyzed using a Guava EasyCyte flow Cytometer running Guava ExpressPlus software (Guava Technologies).

\section{Cell proliferation analysis}

A density of 4,000 cells $/ \mathrm{cm}^{2}$ was plated to each well of a 12-well flat bottom plate in fibroblast growth medium. After $24 \mathrm{~h}$, when total cell adhesion was verified, the fibroblasts were serum-starved for $24 \mathrm{~h}$ and MSCs for $48 \mathrm{~h}$. At the initial time point (Oh), we changed the starvation medium (fibroblast growth medium or MSC growth medium without FBS) for the respective cell growth medium or starvation medium supplemented with $0.5 \%, 10 \%$ and $20 \%$ FBS. At the indicated times, the cells were trypsinized and counted using Guava EasyCyte Flow Cytometer (Guava Technologies). The experiment was done in triplicates for each time point and cell line.

\section{In vitro wound healing assay}

We plated the cells $\left(3 \times 10^{5}\right)$ on 12-well culture plates (Corning) in the respective cell growth medium. Upon reaching $100 \%$ confluence, the fibroblasts were serum-starved for another $24 \mathrm{~h}$ and MSCs for 48h. After starvation, a single wound was created in the center of the cell monolayer by gentle removal of the attached cells with a sterile plastic pipette tip. The cell layer was then scratched with a P200 pipette tip, the debris was removed by washing with PBS (Phosphate Buffered Saline) and we added fibroblast or MSC growth medium. Photographs of the wound adjacent to reference lines scraped on the 
bottom of the plate were taken using an Axio Observer microscope under $5 \times$ field (Zeiss) at $0 \mathrm{~h}$ and $12 \mathrm{~h}$ after the wound was done. We used the ImageJ software and Adobe Photoshop CS3 (Adobe) to analyze and calculate the number of cells that moved into the wound. The experiment was done in triplicates for each treatment and each cell line.

\section{In vitro osteogenic differentiation}

To induce osteogenic differentiation, periosteal fibroblasts and MSCs from three AS patients and from three controls were plated in 24-well plates $\left(5 \times 10^{3}\right.$ cells $\left./ \mathrm{cm}^{2}\right)$ and cultured for three weeks in osteogenic medium (DMEM Low-Glucose, 0.5\% FBS [GIBCO], $0.1 \mathrm{mM}$ dexamethasone (Sigma-Aldrich Corp., St. Louis, MO), $50 \mathrm{mM}$ ascorbate-2-phosphate (Sigma-Aldrich), $10 \mathrm{mM} \beta$-glycerophosphate (Sigma-Aldrich), and 1\% Penicillin Streptomycin [GIBCO]).

For the co-culture assay, the cells were plated at the same concentration onto $12-\mathrm{mm}$ transwell inserts of 12 -well plates, $0.4 \mu \mathrm{m}$ pore size (Corning Costar). Media changes occurred every three to four days. As an internal control of the experiment, the same cells were maintained throughout the 21 days of differentiation in regular growth medium.

Alkaline phosphatase activity was assessed on the 9th day of differentiation through a biochemical assay. The cells were provided with phosphatase substrate (Sigma-Aldrich) and the resulting p-nitrophenol was measured colorimetrically by the use of a Multiskan EX ELISA plate reader (Thermo Scientific) at $405 \mathrm{~nm}$. After 14 and 21 days, calcified matrix production was analyzed by alizarin red staining and quantification was done as previously described(Gregory et al., 2004). 


\section{In vivo osteogenic differentiation}

A $4.5 \mathrm{~mm}$ in diameter ceramic scaffold (60\% hydroxyapatite and $40 \%$ of $\beta$-tricalcium phosphate; Cellceram ScaffdexTM) was moistened with osteogenic medium and mixed with 10 human fibroblasts or MSCs. The cells attached to the scaffold were pre-differentiated in osteogenic medium and incubated at $37^{\circ} \mathrm{C}$ in $5 \% \mathrm{CO}_{2}$ for five days.

For the in vivo differentiation we used 8 non-immunosuppressed (NIS) Wistar rats (all males, aged 2 months, weighing a maximum of $200 \mathrm{~g}$ ) as previously described by our group and approved by the ethical committee of our Institute(De Mendonça Costa et al., 2008). We used a trephine bur of 4.5 $\mathrm{mm}$ diameter to obtain two cranial critical defects which were made in the parietal region, lateral to the sagittal suture, where two scaffolds were implanted per animal, one side being filled by biomaterial alone (left defect) and the other by the biomaterial associated with cells (right defect). The animals were kept in ventilated racks with standard conditions of temperature and lighting $\left(22^{\circ} \mathrm{C}, 12 \mathrm{~h}\right.$ light cycling per day) with free access to food and water. Four weeks after surgery, the rats were sacrificed in a $\mathrm{CO} 2$ chamber. The calvaria was removed and fixed in $10 \%$ formalin for $24 \mathrm{~h}$ and then decalcified in $5 \%$ formic acid for $48 \mathrm{~h}$ and embedded in paraffin. Slices of $5 \mu \mathrm{m}$ were obtained and stained with hematoxylin and eosin.

We analyzed three transversal $4 \mu \mathrm{m}$ slices of the calvaria with $10 \mu \mathrm{m}$ of distance of each animal. Ossification area of each defect was calculated through Axio Vision Carl Zeiss based on 10x amplified images obtained from Axio Observer.A1 Carl Zeiss microscope. The percentage of the defect area that ossified at the right side was normalized by the percentage of the defect area that ossified at the left side, so that for each animal we obtained 3 ratio values. 


\section{JNK inhibitor treatment}

To test for the role of JNK in the enhanced osteogenic potential of S252W fibroblasts, we used the reversible ATP-competitive JNK inhibitor SP600125 (Sigma-Aldrich). Stock solutions of at least 20 mM were made using $100 \%$ dimethyl sulfoxide. First, we evaluated the levels of p-JNK to confirm the inhibition of JNK activity by SP600125, since the inhibitor has been described to downregulate the autophosphorilation activity of JNK(Bennett et al., 2001). Total protein extracts were prepared using Phosphosafe extraction reagent (EMD Biosciences) according to the protocol provided by the manufacturer. The levels of P-JNK were assessed by western blotting. The antibodies used were anti-pJNK (Thr183/Tyr185) Rabbit mAb (Cell Signaling), anti-SAPK/JNK Rabbit mAb (Cell signaling), anti-Rabbit IgG-HRP (Cell Signaling) and Anti-B-actin-HRP (AbCam) (Supplementary figure 1).

During osteogenic differentiation, media were supplemented with $2 \mu \mathrm{M}$ and $4 \mu \mathrm{M}$ of the inhibitor, which corresponds to IC50 and twice the IC50 respectively (Joiakim et al., 2003).

\section{Statistical analysis}

Continuous variables were expressed by mean and standard deviation, and the groups were compared by Student's t-test. A p value $<0.05$ was considered statistically significant. The tests were performed using the GraphPad InStat software (GraphPad). 


\section{Results}

Characterization of the immunophenotype

In order to certify that the results we obtained were representative of the biological variance seen in human patients, we performed all experiments in fibroblast or MSC cultures from three unrelated AS patients (S252W cells) and from three control individuals (WT cells). Each cell culture was studied in three technical replicates.

All cell cultures were adherent and with a fibroblast-like appearance. We performed flow cytometry experiments with different markers in order to characterize the immunophenotype of fibroblast and MSC cultures (Table II.1). S252W and WT cells were highly positive for mesenchymal cell markers (>85\%) and negative for hematopoietic and endothelial cell markers. These results confirm that these cells are of mesenchymal origin.

\section{Cell proliferation and cell migration}

In order to determine the effect of the FGFR2 $2^{5252 \mathrm{~W}}$ mutation in periosteal cells, we first accessed whether the presence of the mutation altered the proliferation rates of S252W fibroblasts and S252W MSCs. The S252W mutation increased cell proliferation in fibroblasts at all times of culture $(24 \mathrm{~h}: \mathrm{p}<$ 0.001, 48 h: $p<0.001 ; 72 \mathrm{~h}: \mathrm{p}<0.001$ ) (Fig.1A) and in different culture conditions $(0.5 \%$ FBS medium: $p=0.014 ; 10 \%$ FBS medium: $p=0.04$; and 20\% FBS medium: $p<0.001$ ) (Fig.1C). On the other hand, in MSCs, the mutation decreased cell proliferation after $72 \mathrm{~h}$ in MSC growth medium (72 $\mathrm{h}: \mathrm{p}=0.002$ ) Fig.1B) and in enriched medium (20\% FBS medium: $p=0.004)$ (Fig.1D). 
Table II.1: Percentage of positive cells for mesenchymal (SH3, CD90, CD29), hematopoietic (CD117 and CD45) and endothelial (CD31) cell lines antibodies.

\begin{tabular}{l|c|c|c|c}
\hline \multirow{2}{*}{} & \multicolumn{2}{|c|}{ MSCs } & \multicolumn{2}{c}{ Fibroblasts } \\
\cline { 2 - 5 } & S252W $(n=2)$ & WT $(n=2)$ & S252W $(n=4)$ & WT $(n=4)$ \\
\hline SH3 & $96,32-99,78 \%$ & $94,7-98,68 \%$ & $88,92-98,45 \%$ & $93,92-97,87 \%$ \\
\hline CD90 & $94,92-95,52 \%$ & $94,02-98,7 \%$ & $89,12-99,7 \%$ & $89,46-98,94 \%$ \\
\hline CD29 & $98,48-99,12 \%$ & $88,1-98,98 \%$ & $85,14-99,02 \%$ & $70-99,25 \%$ \\
\hline CD31 & $<5 \%$ & $<5 \%$ & $<5 \%$ & $<5 \%$ \\
\hline CD117 & $<5 \%$ & $<5 \%$ & $<5 \%$ & $<5 \%$ \\
\hline CD45 & $<5 \%$ & $<5 \%$ & $<5 \%$ & $<5 \%$ \\
\hline
\end{tabular}

We next evaluated the effect of FGFR2S252W on cell migration. The S252W mutation increased cell migration in fibroblasts only in restrictive medium condition (0.5\% FBS medium: $p<0.001$ ) (Fig.1E), but had no effect in MSCs (Fig.1F). 


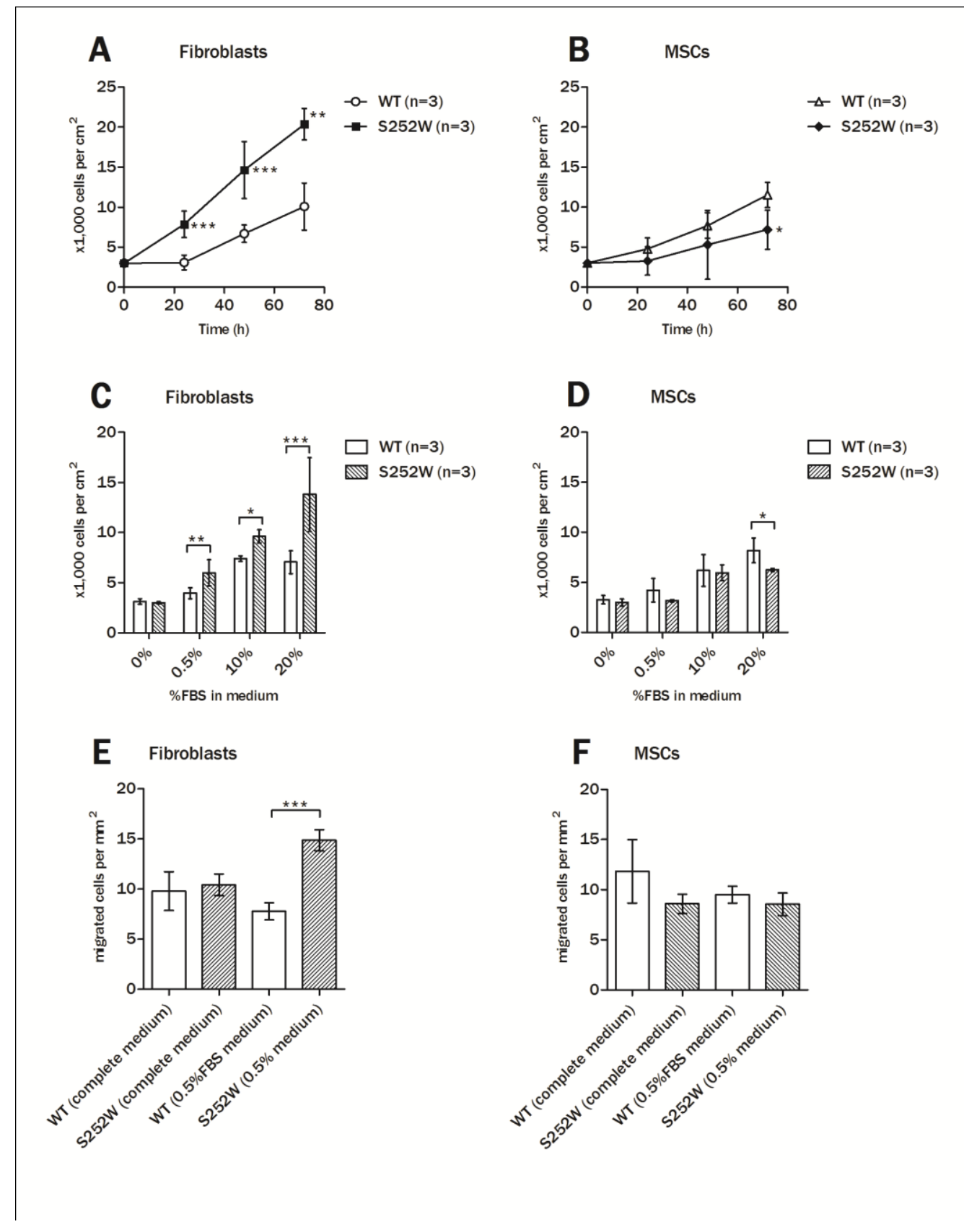

Fig.1: (A) Comparative analysis of the proliferation of WT (from 3 individuals) and S252W (from 3 patients) fibroblasts and (B) WT (from 3 individuals) and S252W (from 3 patients) MSCs. Each point indicates the average for each time and each condition and the error bars represent the standard deviation for the biological replicate (same S252W or WT cell type culture results summed). Analysis of (C) WT (from 3 individuals) and S252W (from 3 patients) fibroblasts and (D) WT (from 3 individuals) and S252W (from 3 patients) MSCs when grown in culture medium with different FBS concentration. Each point indicates the average of each medium after $48 \mathrm{~h}$ and the error bars represent the standard deviation for the biological replicate. $(E)$ Wound healing assay of S252W $(n=3)$ and WT $(n=3)$ fibroblasts and $(F)$ and S252W $(n=3)$ and WT $(n=3)$ MSCs in high FBS and low FBS growth medium. The bars represent the average number of cells that migrated toward the wound after $12 \mathrm{~h}$ for each condition and error bars represent the standard deviation for the biological replicate $\left(*: p<0.05,{ }^{* *}: p<0.01,{ }^{* * *}: p<0.001\right)$. 
In vitro osteogenic differentiation

Next, we assessed the effects of the S252W mutation on osteogenic differentiation. We performed experiments at key points of our in vitro differentiation protocol in order to evaluate whether the mutation plays a more prominent part at a specific stage of osteogenic differentiation. The ninth day of differentiation is ideal to access the levels of alkaline phosphatase (ALP) in cultures, as in this period there is a peak production of the enzyme. ALP provides the phosphate needed for the production of cellular matrix calcium. S252W fibroblasts showed 6-fold increase in ALP activity in comparison to WT fibroblasts ( $p<0.001$ ) (Fig.2A), while S252W MSCs had 3-fold increase in comparison to WT MSCs ( $p<0.001)$ (Fig.2B).

After two weeks in osteogenic medium, we analyzed initial calcium deposition in the extracellular matrix (ECM) through alizarin red staining. S252W fibroblasts showed 2.7-fold increase in ECM calcium in comparison to WT fibroblasts ( $p<0.001$ ) (Fig.2C), while S252W MSCs had 1.5-fold increase in comparison to WT MSCs ( $p=0.016)$ (Fig.2D).

Finally, we evaluated concentration of ECM calcium at the end of differentiation (21st day). S252W fibroblasts showed a 1.7-fold increase in ECM calcium in comparison to WT fibroblasts $(p=0.002)$ (Fig.2E), while S252W MSCs had a 1.5-fold increase in comparison to WT MSCs ( $p<0.001)$ (Fig.2F).

In vivo osteogenic differentiation 
To validate these data in vivo, we performed the bilateral cranial critical defect experiment using Wistar NIS rats as previously described by our group (De Mendonça Costa et al., 2008).At the right-side defect we introduced either S252W or WT cells associated with biomaterial, and at the left-side defect we introduced biomaterial only as an internal control of each animal's osteoregeneration.

Four weeks after the surgery, the right-side:left-side ossification ratio was 4.9 in S252W fibroblasts and 1.9 compared to WT fibroblasts (2.6-fold higher; $p=0.036$ ) (Fig.2G). Likewise, this ratio was 11.8 in S252W MSCs and 2.6 in WT MSCs (4.5-fold higher; $p=0.001$ ) (Fig.2H). 


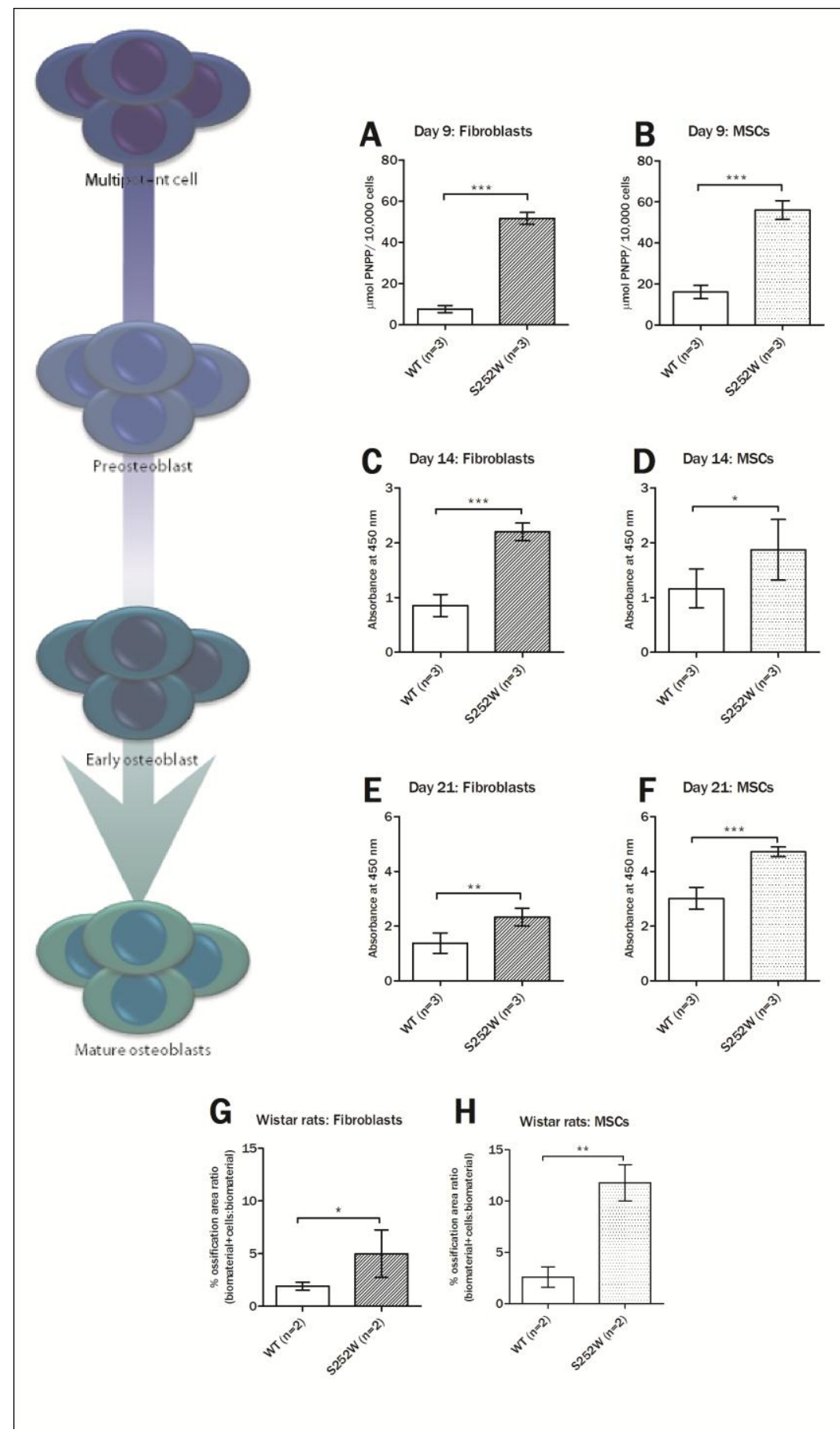

Fig.2: S252W and WT fibroblasts and MSCs (all conditions: $n=3$ ) in response to osteogenic medium during different phases of osteogenic differentiation. (A, B) Analysis of alkaline phosphatase activity on the 9th day of osteogenic differentiation; (C, D) alizarin red staining quantification at the 14th day of differentiation; (E, F) alizarin red staining quantification at the 21st day of osteogenic differentiation. The columns represent the absorbance at wavelength indicated for each condition and error bars represent the standard deviation for the biological replicate. (G) Percentage of ossification area of calvarial defects with WT or S252W fibroblasts in rats 4 weeks after surgery. $(\mathrm{H})$ Percentage of ossification area of calvarial defects with WT or S252W MSCs in rats 4 weeks after surgery $(*: p<0.05 ; * *: p<0.01 ; * * *: p<0.001)$. 
Interactions between periosteal MSCs and fibroblasts during osteogenic differentiation.

As shown above, we observed in vitro and in vivo that the cellular phenotype alterations due to S252W mutation seemed more drastic in fibroblasts than in MSCs, and that S252W fibroblasts are particularly more prone to osteogenic differentiation. These data thus raised the question whether S252W fibroblasts could induce osteogenic differentiation in other cells.

Therefore, in order to test the hypothesis that a cell population with the S252W mutation alters normal signaling in adjacent cells, we used a co-culture system to simulate the in vivo anatomic link between the fibroblasts and MSCs in the periosteum, allowing the paracrine signaling without physical cell interaction. S252W fibroblasts induced 30\% more differentiation of periosteal MSCs, whether WT $(n=3)$ or S252W ( $n=2)$, both by ALP assay (WT MSCs: $p<0.001$; S252W MSCs: $p=0.037)$ and alizarin red staining (vs. WT MSCs: $p=0.007$; vs. S252W MSCs: $p=0.016$ ) (Fig. $3 \mathrm{~A}$ and $3 C$ ). Interestingly, S252W fibroblasts did not induce osteogenic differentiation of MSC from another tissue, such as dental pulp stem cells (DPSC) (Fig.3A and 3C). Further, S252W MSCs and WT MSCs exhibit no influence on the osteogenic differentiation of S252W fibroblasts (Fig.3B and 3D). 


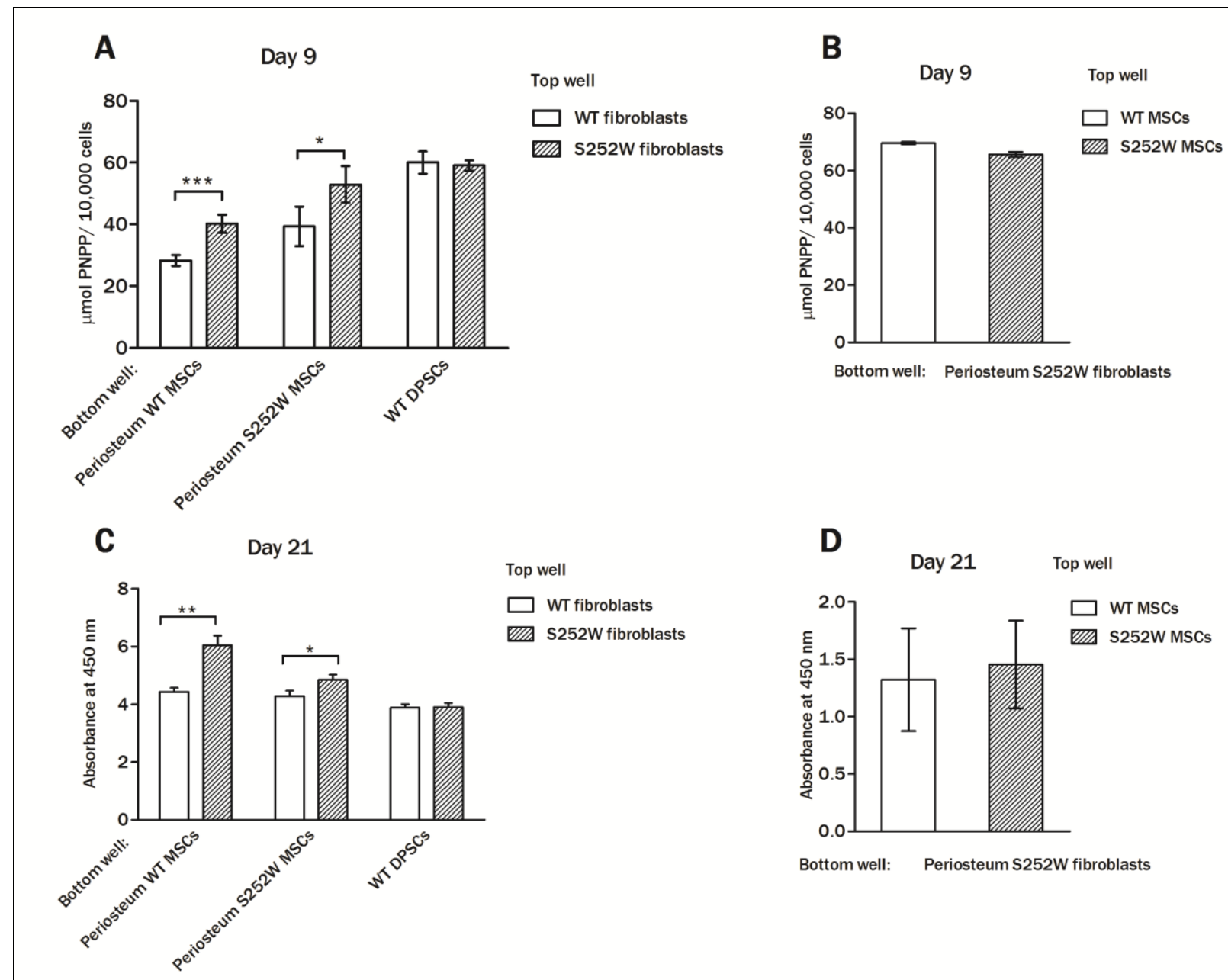

Fig.3: Effects of interaction between periosteal MSCs and fibroblasts. (A) Analysis of alkaline phosphatase activity on the 9th day and (C) alizarin red staining at the 21st day of osteogenic differentiation of S252W MSCs ( $n=2)$, WT MSCs $(n=2)$ and WT DPSC ( $n=1)$ co-cultured with fibroblasts with or without the mutation in the presence of osteogenic medium. (B) Analysis of alkaline phosphatase activity on the 9th day and (D) alizarin red staining at the 21st day of osteogenic differentiation of S252W fibroblast $(n=1)$ co-cultured with MSCs with or without the mutation in the presence of osteogenic medium. The columns represent the absorbance at wavelength indicated for each condition and error bars represent the standard deviation for the biological replicate $\left(^{*}: p<0.05, * *: p\right.$ $<0.01, * * *: p<0.001)$.

\section{Potential molecule involved in altered fibroblast osteogenic potential}

To assess whether JNK plays a role in the increased osteogenic potential of S252W fibroblasts, we treated S252W fibroblasts with $2 \mu \mathrm{M}$ (IC50)(Joiakim et al., 2003) and $4 \mu \mathrm{M}$ (twice IC50) of SP600125, a JNK phosphorylation inhibitor, during osteogenic differentiation. We observed a lower ALP activity as 
we increased the concentration of SP600125 (untreated vs. $+2 \mu \mathrm{M}$ SP600125: $p=0.025 ;+2 \mu \mathrm{M}$ SP600125 vs. $+4 \mu \mathrm{M}$ SP600125: $\mathrm{p}=0.014$ ). This effect was also observed by alizarin red staining (untreated vs. +2 $\mu \mathrm{M}$ SP600125: $\mathrm{p}=0.006$; untreated vs. $+4 \mu \mathrm{M}$ SP600125: $\mathrm{p}=0.003$ ) (Fig.4A and 4B). At the maximal inhibition of JNK (4 $\mu \mathrm{M})$, ALP activity of S252W fibroblast and WT fibroblasts were equivalent. Therefore, inhibition of JNK activity rescued the increased osteogenic potential of S252W fibroblasts.

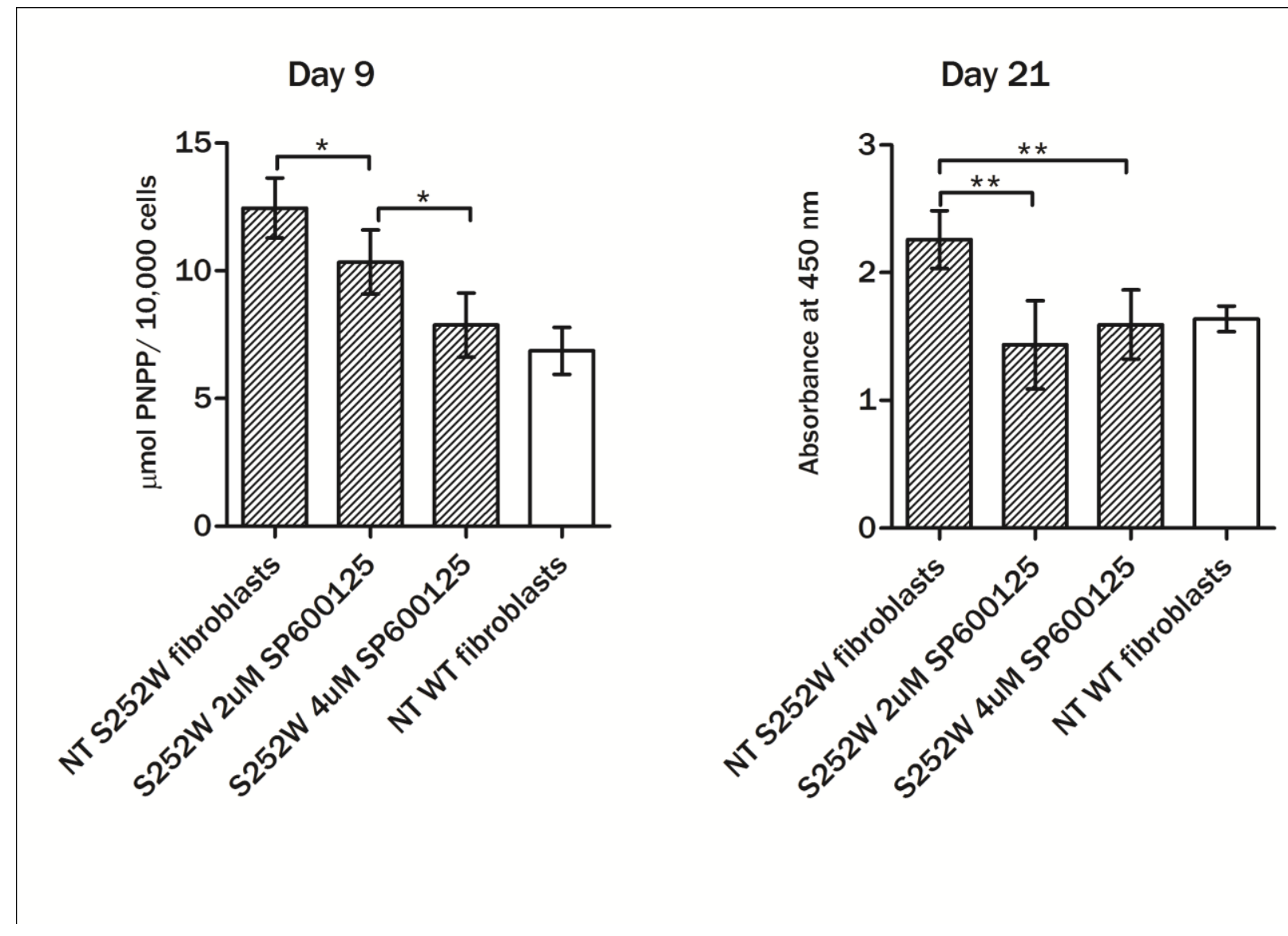

Fig.4: Effects of JNK inhibition in periosteal S252W ( $n=2)$ and WT $(n=2)$ fibroblasts. (A) Analysis of alkaline phosphatase activity on the 9th day of osteogenic differentiation. (B) Alizarin red staining quantification at the 21st day of osteogenic differentiation. The columns represent the absorbance at wavelength indicated for each condition and error bars represent the standard deviation for the biological replicate $(*: p<0.05, * *: p<0.01, * * *: p<0.001)$. 


\section{Discussion}

The only treatment available nowadays for AS patients is surgical intervention, which consists of artificial reconstruction of the coronal sutures(Posnick et al., 1995). Nevertheless, post-surgical ossification of the sutures (resynostosis) is frequent and any surgical treatment for craniosynostosis during childhood is considered a procedure to delay but not to prevent synostosis (Cohen Jr. et al., 2000). To understand the cause and prevent resynostosis of the sutures so that they remain open during the growth phase of the individual, it is important to identify the main molecules and mechanisms involved in this process. This knowledge can contribute to a better management of the affected child, enhancing their life quality. Bone regeneration studies have pointed to the periosteum as a significant contributor to the ossification process (Hosoi, 2010; Ito et al., 2001), not only through molecular signaling, but also by providing osteoprogenitor cells [26]. Despite the periosteum's possible contribution to premature suture ossification in AS and other craniosynostosis, the mechanism by which FGFR2 gain-of-function mutations achieve this effect is not clear. Unbalanced FGF signaling can accelerate proliferation, migration, and differentiation in osteoprogenitor cells from the periosteum and contribute to resynostosis, though this process continues to be poorly understood, particularly in AS patients. Study of cells derived from the periosteum of the AS patients can help to elucidate these questions, as we can compare the effect of the mutation in different cell types from the same niche. This could be of particular relevance considering that cell signaling can be different between mice and humans, and that the range of phenotypic effects of a mutation is not always the same in both (Bulfield, 1984; Dhillon et al., 2010; Harries et al., 2009). Here we successfully established fibroblasts and MSCs cell cultures from the periosteum of both AS and control individuals. In accordance to the literature (Posnick et al., 1995), we were not able to distinguish these two cell types based on morphology and positive staining for mesenchymal cell markers. However, the positive bone differentiation seen in WT 
MSCs but not in WT fibroblasts confirms that our protocols allow for the establishment of two distinct cell populations, as we have shown in our previous reports (Daniela Franco Bueno et al., 2009; R.D. Fanganiello et al., 2007).

The S252W mutation enhanced cell proliferation in fibroblasts, even in critical culture conditions, such as $0.5 \%$ FBS medium, but it had a negative effect on MSCs in $20 \%$ FBS culture environment. Literature data regarding the presence of $F G F R 2^{5252 \mathrm{~W}}$ and cell proliferation are controversial. Some studies that investigated human periosteal fibroblasts (R.D. Fanganiello et al., 2007), murine osteoblasts (F. Yang et al., 2008), murine stem cells (Miraoui et al., 2009), or calvarial cells during embryonic sutures formation in murine AS models (Holmes et al., 2009; Y. Wang et al., 2002)point to the FGFR2 ${ }^{\mathrm{S252W}}$ mutation as respon(Miraoui et al., 2009)sible for increasing cell proliferation. Interestingly, the murine MSCs with FGFR3 mutation proliferate less than the wild type cells (Su et al., 2010).

These comparative analyses are complex, as the experiments have not only included different cell types but also cells from different species and from different niches. Therefore, although we cannot rule out differences in the protocols used, our results suggest that the effect of the FGFR2 ${ }^{\mathrm{S} 252 \mathrm{~W}}$ mutation on cell proliferation might depend both on the tissue, niche of origin, and cell type under analysis, which would explain at least in part the controversy in the literature.

Through the wound healing assay, we have shown that FGFR2 ${ }^{\mathrm{S} 252 \mathrm{~W}}$ has an effect on the migratory property of fibroblasts, but not of MSCs. This effect on the fibroblasts, however, was dependent on the availability of FBS, a culture medium supplement that provides not only growth factors, but also cellular growth inhibitors (Freshney, 2005). It was previously reported that FGFR2 ${ }^{\text {S252W }}$ has enhanced affinity to different FGFs (O. A. Ibrahimi, F Zhang, et al., 2004), therefore, the altered S252W cell proliferation and cell migration in response to different FBS concentrations suggests that FBS contains growth stimulating FGFs to which S252W fibroblasts are more sensitive to, and FGFs that in 
high concentration inhibit migration of S252W fibroblasts. It is possible that during embryonic and even post-natal development, atypical cell responses are dependent on which FGF is available at that period.

Regarding the osteogenic potential, we found that FGFR2 $2^{5252 \mathrm{~W}}$ induces increased osteogenic differentiation in both cell types under study, especially at the early stages of the in vitro process. We were able to confirm these results in vivo using non-immunosuppressed rats and human cells, as an increased ossification rate was observed for both fibroblasts and MSCs harboring the FGFR2 $2^{5252 \mathrm{~W}}$ mutation as compared to corresponding WT cells. These results thus confirm our preliminary work on S252W fibroblasts (Bulfield, 1984) which showed that the FGFR2 ${ }^{\mathrm{S} 252 \mathrm{~W}}$ mutation confers a new function to these cells. In addition, our results for MSCs, the osteoblast precursors, are in agreement with most of the literature, ranging from studies with murine stem cells to human pre-osteoblasts transfected with FGFR2 $^{\mathrm{S252W}}$, which showed that the FGFR2 ${ }^{\mathrm{S} 252 \mathrm{~W}}$ mutation enhances osteogenic potential (Lomri et al., 1998; Miraoui et al., 2009; F. Yang et al., 2008).

A dynamic system based on integrated signals between stem cells and cells from their surrounding niche, such as fibroblasts, is necessary to maintain proper tissue physiology (Scadden, 2006). Thus, we judged it necessary to evaluate the effect of S252W fibroblasts on the MSCs, the expected osteoblast precursors. Interestingly, our co-culture assay showed that the presence of S252W fibroblasts promotes osteogenic differentiation of both S252W and WT periosteal MSCs.

In addition, S252W fibroblasts did not induce osteogenic differentiation in DPSC, which suggests that the cells we used must still harbor regulatory network programs that are specific to the tissue from which they are extracted and that are not erased in cell culture. The increased osteogenic potential of S252W fibroblasts seems to be mediated by JNK, since JNK inhibition reverted this phenotype. Shukla et al. demonstrated that ERK (extracellular-signal-regulated kinase) is directly involved in the craniosynostosis in a Fgfr2 ${ }^{+/ s 252 \mathrm{~W}}$ mouse(Shukla et al., 2007). 
Futhermore, ERK indirectly increases JNK activity (Lopez-Bergami et al., 2007). Our findings thus suggest that ERK-JNK pathway is also disturbed in human AS patients and that a key molecule involved in craniosynostosis lies downstream to ERK and JNK. Altogether, we propose that identifying this key molecule might have a better therapeutic potential in the surgical treatment of AS patients than ERK and JNK inhibitors, as inhibition of either molecule leads to severe side effects as both are involved in important signaling pathway in the whole organism. We cannot rule out the possibility that other MAPKs, such as $\mathrm{p} 38$, downstream to FGFR activation might be responsible for the increased osteogenic potential in the S252W fibroblasts, as these molecules have been shown to have enhance activation in Apert mouse models (Ge et al., 2007; Marie, 2003; Shukla et al., 2007; Su et al., 2010; Y. Wang et al., 2010).

Based on our results, we propose that the FGFR2 ${ }^{\mathrm{S} 252 \mathrm{~W}}$ mutation confers a most pronounced gain-of-function in fibroblast cells. Of the cell phenotypes evaluated, the most strikingly altered one is their increased osteogenic potential. This represents an acquired new function for fibroblasts, apparently mediated by JNK pathway. It has been suggested that the premature suture fusion in S252W cells is a result of excessive cell proliferation (Beenken et al., 2009). In the present study, FGFR2 ${ }^{\text {S252W }}$ mutation leads to increased proliferation, migration, and osteogenic potential of both fibroblasts and MSCs. Therefore, the premature ossification process might result from a more complex mechanism than only alteration of the proliferative capacity. Further, we show that fibroblasts enhance the osteogenic potential of MSCs of the same niche. These results allow us to suggest that periosteum cells might contribute to premature suture fusion in these patients (Fig.5), a characteristic that has previously been attributed to dura mater (Lopez-Bergami et al., 2007). To better understand the molecular mechanisms underlying our findings, it is crucial to identify molecules secreted by S252W fibroblasts that may contribute to intensify osteogenic differentiation in other cells and whether they are related to the JNK 
pathway. These molecules could lead to the identification of candidate drugs that could ameliorate the surgical prognosis of AS patients.

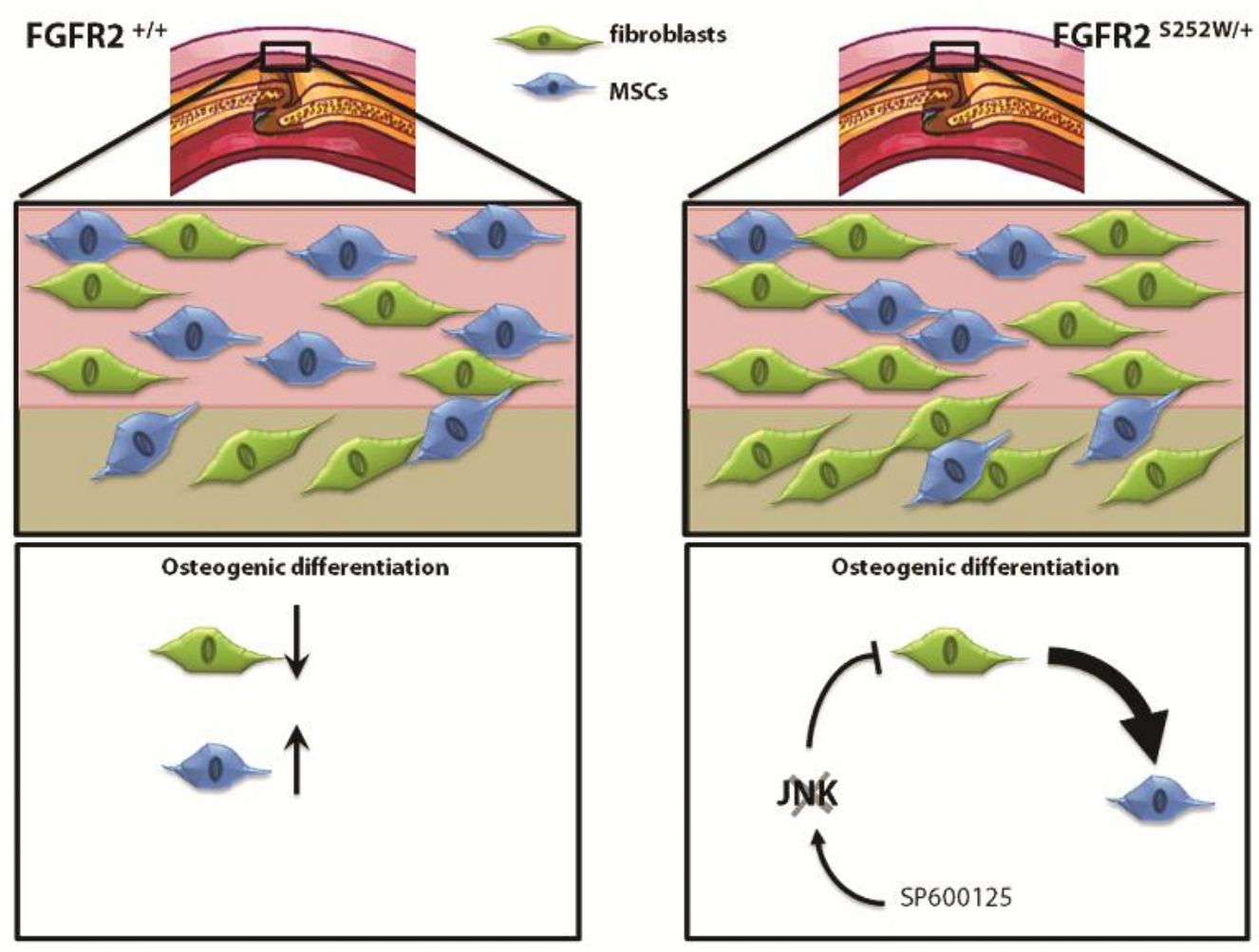

Fig.5: In the periosteum (pink) overlying the suture (brown), fibroblasts (green cells) and MSCs (blue cells) have similar cell growth and cell migration rates. However, fibroblasts exhibit low while MSCs show higher osteogenic potential (left). The FGFR2S252W mutation has a positive effect on both proliferation and migration of fibroblasts, and a negative effect on MSC proliferation. It has no consequence on MSCs migration. Both cell types have enhanced osteogenic differentiation and S252W fibroblasts show positive influence on MSCs differentiation. Inhibition of JNK phosphorylation by SP600125 can null the effect of the mutation over osteogenic differentiation of fibroblasts.

\section{Bibliography}


Alberius, P., Dahlin, C., \& Linde, A. (1992). Role of osteopromotion in experimental bone grafting to the skull: a study in adult rats using a membrane technique. Journal of oral and maxillofacial surgery official journal of the American Association of Oral and Maxillofacial Surgeons, 50(8), 829-834.

Allen, M. R., Hock, J. M., \& Burr, D. B. (2004). Periosteum: biology, regulation, and response to osteoporosis therapies. Bone, 35(5), 1003-12. doi:10.1016/j.bone.2004.07.014

Ang, B. U., Spivak, R. M., Nah, H.-D., \& Kirschner, R. E. (2010). Dura in the pathogenesis of syndromic craniosynostosis: fibroblast growth factor receptor 2 mutations in dural cells promote osteogenic proliferation and differentiation of osteoblasts. The Journal of craniofacial surgery, 21(2), 462-467.

Armelin, H. a. (1973). Pituitary extracts and steroid hormones in the control of 3T3 cell growth. Proceedings of the National Academy of Sciences of the United States of America, 70(9), 2702-6. Retrieved from http://www.pubmedcentral.nih.gov/articlerender.fcgi?artid=427087\&tool=pmcentrez\&rendertyp $\mathrm{e}=\mathrm{abstract}$

Artun, J., Osterberg, S. K., \& Kokich, V. G. (1986). Long-term effect of thin interdental alveolar bone on periodontal health after orthodontic treatment. The Journal of periodontology, 57(6), 341-346. Retrieved from http://www.informaworld.com/10.1080/10131750608540424

Aubin, J. E., Gupta, A. K., Bhargava, U., \& Turksen, K. (1996). Expression and regulation of galectin 3 in rat osteoblastic cells. Journal of Cellular Physiology, 169(3), 468-480. Retrieved from http://www.ncbi.nlm.nih.gov/pubmed/8952696

Beenken, A., \& Mohammadi, Moosa. (2009). The FGF family: biology, pathophysiology and therapy. Nature reviews. Drug discovery, 8(3), 235-53. doi:10.1038/nrd2792

Bennett, B. L., Sasaki, D. T., Murray, B. W., O’Leary, E. C., Sakata, S. T., Xu, W., Leisten, J. C., et al. (2001). SP600125, an anthrapyrazolone inhibitor of Jun N-terminal kinase. Proceedings of the National Academy of Sciences of the United States of America, 98(24), 13681-13686. The National Academy of Sciences. Retrieved from http://www.pubmedcentral.nih.gov/articlerender.fcgi?artid=61101\&tool=pmcentrez\&rendertype $=\mathrm{abstract}$

Bueno, Daniela Franco, Kerkis, I., Costa, A. M., Martins, M. T., Kobayashi, G. S., Zucconi, E., Fanganiello, Roberto Dalto, et al. (2009). New source of muscle-derived stem cells with potential for alveolar bone reconstruction in cleft lip and/or palate patients. Tissue engineering Part A, 15(2), 427-435. Retrieved from http://www.ncbi.nlm.nih.gov/pubmed/18816169

Bulfield, G. (1984). X Chromosome-Linked Muscular Dystrophy (mdx) in the Mouse. Proceedings of the National Academy of Sciences, 81(4), 1189-1192. doi:10.1073/pnas.81.4.1189 
Bullaughey, K., Chavarria, C. I., Coop, G., \& Gilad, Y. (2009). Expression quantitative trait loci detected in cell lines are often present in primary tissues. Human Molecular Genetics, 18(22), 4296-4303. Oxford University Press. Retrieved from

http://www.pubmedcentral.nih.gov/articlerender.fcgi?artid=2766291\&tool=pmcentrez\&renderty pe $=$ abstract

Bunney, T. D., \& Katan, M. (2011). PLC regulation: emerging pictures for molecular mechanisms. Trends in biochemical sciences, 36(2), 88-96. Elsevier Ltd.

doi:10.1016/j.tibs.2010.08.003

Chalhoub, N., \& Baker, S. J. (2009). PTEN and the PI3-kinase pathway in cancer. Annual review of pathology, 4(1), 127. NIH Public Access. doi:10.1146/annurev.pathol.4.110807.092311.PTEN

Chellaiah, A. T., McEwen, D. G., Werner, S., Xu, J., \& Ornitz, D M. (1994). Fibroblast growth factor receptor (FGFR) 3. Alternative splicing in immunoglobulin-like domain III creates a receptor highly specific for acidic FGF/FGF-1. The Journal of Biological Chemistry, 269(15), 11620-11627. Retrieved from http://www.ncbi.nlm.nih.gov/pubmed/7512569

Chen, L. (2003). A Ser250Trp substitution in mouse fibroblast growth factor receptor 2 (Fgfr2) results in craniosynostosis. Bone, 33(2), 169-178. doi:10.1016/S8756-3282(03)00222-9

Cohen JR, M. M., \& Kreiborg, S. (1992). New indirect method for estimating the birth prevalence of the Apert syndrome. Int J Oral Maxillofac Surg, 21(2), 107-109.

Cohen Jr., M. M., \& MacLean, R. E. (2000). Craniosynostosis. Diagnosis, Evaluation and Management (Second.).

Cohen, M M. (1975). An etiologic and nosologic overview of craniosynostosis syndromes. Birth Defects Original Article Series, 11(2), 137-189. Retrieved from

http://www.ncbi.nlm.nih.gov/entrez/query.fcgi?cmd=Retrieve \&db=PubMed\&dopt=Citation\&list _uids $=179637$

Cohen, M Michael. (1986). Perspectives on craniosynostosis. The Journal of craniofacial surgery, 20 Suppl 1, 646-51. doi:10.1097/SCS.0b013e318193d48d

Colnot, C. (2009). Skeletal cell fate decisions within periosteum and bone marrow during bone regeneration. Journal of bone and mineral research the official journal of the American Society for Bone and Mineral Research, 24(2), 274-282.

Dhillon, K. K., Sidorova, J. M., Albertson, T. M., Anderson, J. B., Ladiges, W. C., Rabinovitch, P. S., Preston, B. D., et al. (2010). Divergent cellular phenotypes of human and mouse cells lacking the Werner syndrome RecQ helicase. DNA Repair, 9(1), 11-22. Elsevier B.V. Retrieved from http://www.ncbi.nlm.nih.gov/pubmed/19896421 
Eswarakumar, V. P., Lax, I., \& Schlessinger, J. (2005). Cellular signaling by fibroblast growth factor receptors. Cytokine \& growth factor reviews, 16(2), 139-49. Oxford, UK: Elsevier Science Ltd., c1996-. doi:10.1016/j.cytogfr.2005.01.001

Fakhry, A., Ratisoontorn, C., Vedhachalam, C., Salhab, I., Koyama, E., Leboy, P., Pacifici, M., et al. (2005). Effects of FGF-2/-9 in calvarial bone cell cultures: differentiation stage-dependent mitogenic effect, inverse regulation of BMP-2 and noggin, and enhancement of osteogenic potential. Bone, 36(2), 254-66. doi:10.1016/j.bone.2004.10.003

Fanganiello, R.D., Sertié, A.L., Reis, E. M., Yeh, E., Oliveira, N. A. J., Bueno, D.F., Kerkis, I., et al. (2007). Apert p. Ser252Trp mutation in FGFR2 alters osteogenic potential and gene expression of cranial periosteal cells. Molecular Medicine, 13(7-8), 422. The Feinstein Institute for Medical Research. doi:10.2119/2007

Foster, K. A., Frim, D. M., \& McKinnon, M. (2008). Recurrence of synostosis following surgical repair of craniosynostosis. Plastic and Reconstructive Surgery, 121(3), 70e-76e. Retrieved from http://www.ncbi.nlm.nih.gov/pubmed/18317088

Freshney, R. I. (2005). Culture of animal cells: a manual of basic technique. (J. W. Sons, Ed.)4th ed New York WileyLiss (Vol. 42, p. 642). John Wiley \& Sons. doi:10.1290/BR090501.1

Furdui, C. M., Lew, E. D., Schlessinger, Joseph, \& Anderson, K. S. (2006). Autophosphorylation of FGFR1 kinase is mediated by a sequential and precisely ordered reaction. Molecular cell, 21(5), 711-7. doi:10.1016/j.molcel.2006.01.022

Ge, C., Xiao, G., Jiang, D., \& Franceschi, R. T. (2007). Critical role of the extracellular signalregulated kinase-MAPK pathway in osteoblast differentiation and skeletal development. The Journal of Cell Biology, 176(5), 709-718. The Rockefeller University Press. Retrieved from http://www.pubmedcentral.nih.gov/articlerender.fcgi?artid=2064027\&tool=pmcentrez\&renderty pe $=$ abstract

Givol, D. (1992). Complexity of FGF receptors: genetic basis for structural diversity and functional specificity. The FASEB journal official publication of the Federation of American Societies for Experimental Biology, 6(15), 3362-3369. Retrieved from http://www.fasebj.org/cgi/reprint/6/15/3362.pdf

Glaser, R. L., Broman, K. W., Schulman, R. L., Eskenazi, B., Wyrobek, A. J., \& Jabs, Ethylin Wang. (2003). The paternal-age effect in Apert syndrome is due, in part, to the increased frequency of mutations in sperm. The American Journal of Human Genetics, 73(4), 939-947. The American Society of Human Genetics. Retrieved from http://www.pubmedcentral.nih.gov/articlerender.fcgi?artid=1180614\&tool=pmcentrez\&renderty pe $=$ abstract

Gospodarowicz, D. (1974). Localisation of a fibroblast growth factor and its effect alone and with hydrocortisone on 3 T3 cell growth. Nature, 249(453), 123-127. Retrieved from http://www.ncbi.nlm.nih.gov/pubmed/4364816 
Gregory, C. A., Gunn, W. G., Peister, A., \& Prockop, D. J. (2004). An Alizarin red-based assay of mineralization by adherent cells in culture: comparison with cetylpyridinium chloride extraction. Analytical biochemistry, 329(1), 77-84. doi:10.1016/j.ab.2004.02.002

Guicheux, J., Lemonnier, J., Ghayor, C., Suzuki, A., Palmer, G., \& Caverzasio, J. (2003). Activation of p38 mitogen-activated protein kinase and c-Jun-NH2-terminal kinase by BMP-2 and their implication in the stimulation of osteoblastic cell differentiation. Journal of bone and mineral research the official journal of the American Society for Bone and Mineral Research, 18(11), 2060-2068. Retrieved from http://www.ncbi.nlm.nih.gov/pubmed/14606520

Haley, P. J. (2003). Species differences in the structure and function of the immune system. Toxicology, 188(1), 49-71. Elsevier. Retrieved from http://linkinghub.elsevier.com/retrieve/pii/S0300483X0300043X

Harries, L. W., Brown, J. E., \& Gloyn, A. L. (2009). Species-Specific Differences in the Expression of the HNF1A, HNF1B and HNF4A Genes. (B. Breant, Ed.)PLoS ONE, 4(11), 7. Public Library of Science.

Holmes, G., Rothschild, G., Roy, U. B., Deng, C.-xia, Mansukhani, A., Basilico, C., \& Basu, U. (2009). Early onset of craniosynostosis in an Apert mouse model reveals critical features of this pathology. Developmental biology, 328(2), 273-84. Elsevier Inc.

doi:10.1016/j.ydbio.2009.01.026

Hosoi, T. (2010). Genetic aspects of osteoporosis. Journal of Bone and Mineral Metabolism, 28(6), 601-607. Retrieved from http://www.ncbi.nlm.nih.gov/pubmed/20697753

Ibrahimi, O. A., Zhang, F, Eliseenkova, A. V., Itoh, N, Linhardt, R J, \& Mohammadi, M. (2004). Biochemical analysis of pathogenic ligand-dependent FGFR2 mutations suggests distinct pathophysiological mechanisms for craniofacial and limb abnormalities. Hum Mol Genet, 13, 2313-2324. doi:10.1093/hmg/ddh235

Ibrahimi, O., Zhang, Fuming, Hrstka, S. C. L., Mohammadi, Moosa, \& Linhardt, Robert J. (2004). Kinetic model for FGF, FGFR, and proteoglycan signal transduction complex assembly. Biochemistry, 43(16), 4724-30. doi:10.1021/bi0352320

Ito, Y., Sanyal, A., Fitzsimmons, J. S., Mello, M. A., \& O’Driscoll, S. W. (2001).

Histomorphological and proliferative characterization of developing periosteal neochondrocytes in vitro. Journal of Orthopaedic Research, 19(3), 405-413. Retrieved from http://www.ncbi.nlm.nih.gov/pubmed/11398853

Jeffrey, K. L., Brummer, T., Rolph, M. S., Liu, S. M., Callejas, N. A., Grumont, R. J., Gillieron, C., et al. (2006). Positive regulation of immune cell function and inflammatory responses by phosphatase PAC-1. Nature immunology, 7(3), 274-83. doi:10.1038/ni1310

Jehee, F. S., Krepischi-Santos, a C. V., Rocha, K. M., Cavalcanti, D. P., Kim, C. a, Bertola, D. R., Alonso, L. G., et al. (2008). High frequency of submicroscopic chromosomal imbalances in 
patients with syndromic craniosynostosis detected by a combined approach of microsatellite segregation analysis, multiplex ligation-dependent probe amplification and array-based comparative genome. Journal of medical genetics, 45(7), 447-50. doi:10.1136/jmg.2007.057042

Johnson, David. (2003). A comprehensive screen of genes implicated in craniosynostosis. Annals of the Royal College of Surgeons of England, 85(6), 371-377. The Royal College of Surgeons of England. Retrieved from

http://www.ingentaconnect.com/content/rcse/arcs/2003/00000085/00000006/art00001

Joiakim, A., Mathieu, P. A., Palermo, C., Gasiewicz, T. A., \& Reiners, J. J. (2003). The Jun Nterminal kinase inhibitor SP600125 is a ligand and antagonist of the aryl hydrocarbon receptor. Drug metabolism and disposition the biological fate of chemicals, 31(11), 1279-1282. Retrieved from

http://www.ncbi.nlm.nih.gov/entrez/query.fcgi? $\mathrm{cmd}=$ Retrieve $\& \mathrm{db}=$ PubMed\&dopt=Citation \&list _uids $=14570754$

Kholodenko, B. N., \& Birtwistle, M. R. (2009). Four-dimensional dynamics of MAPK information-processing systems. Cell. doi:10.1002/wsbm.016

Kimonis, V., Gold, J.-anne J., Hoffman, T. T. L., Panchal, J., \& Boyadjiev, S. A. (2007). Genetics of craniosynostosis. Seminars in Pediatric Neurology, 1-3. doi:10.1016/j.spen.2007.08.008

Klint, P., \& Claesson-Welsh, L. (1999). Signal transduction by fibroblast growth factor receptors. Front Biosci, 4(22), D165-77. Retrieved from http://www.bioscience.org/1999/v4/d/klint/fulltext.htm

Krishna, M., \& Narang, H. (2008). Review The complexity of mitogen-activated protein kinases ( MAPKs ) made simple. Cellular and Molecular Life Sciences, 65, 3525 - 3544. doi:10.1007/s00018-008-8170-7

Lajeunie, E., Cameron, R., El Ghouzzi, V., De Parseval, N., Journeau, P., Gonzales, M., Delezoide, A. L., et al. (1999). Clinical variability in patients with Apert's syndrome. Journal Of Neurosurgery, 90(3), 443-447. Retrieved from http://www.ncbi.nlm.nih.gov/pubmed/10067911

Langille, R. M. (1994). Chondrogenic differentiation in cultures of embryonic rat mesenchyme. Microscopy Research and Technique, 28(6), 455-469.

Lemmon, M. A., \& Schlessinger, Joseph. (2010). Cell signaling by receptor tyrosine kinases. Cell, 141(7), 1117-34. doi:10.1016/j.cell.2010.06.011

Levine, J. P., Bradley, J. P., Roth, D. A., McCarthy, J. G., \& Longaker, M T. (1998). Studies in cranial suture biology: regional dura mater determines overlying suture biology. Plastic and Reconstructive Surgery, 101(6), 1441-1447. 
Li, Chaoying, Scott, D. a, Hatch, E., Tian, X., \& Mansour, S. L. (2007). Dusp6 (Mkp3) is a negative feedback regulator of FGF-stimulated ERK signaling during mouse development. Development (Cambridge, England), 134(1), 167-76. doi:10.1242/dev.02701

Lilli, C., Bellucci, C., Baroni, T., Aisa, C., Carinci, P., Scapoli, L., Carinci, F., et al. (2007). FGF2 effects in periosteal fibroblasts bearing the FGFR2 receptor Pro253 Arg mutation. Cytokine, 38(1), 22-31.

Liu, H., Liu, Y., Viggeswarapu, M., Zheng, Z., Titus, L., \& Boden, S. D. (2010). Activation of cJun NH(2)-terminal kinase 1 increases cellular responsiveness to BMP-2 and decreases binding of inhibitory Smad6 to the type I BMP receptor. Journal of bone and mineral research : the official journal of the American Society for Bone and Mineral Research, 404-417. doi:10.1002/jbmr.296

Lomri, a, Lemonnier, J., Hott, M., de Parseval, N., Lajeunie, E., Munnich, a, Renier, D., et al. (1998). Increased calvaria cell differentiation and bone matrix formation induced by fibroblast growth factor receptor 2 mutations in Apert syndrome. The Journal of clinical investigation, 101(6), 1310-7. Retrieved from http://www.pubmedcentral.nih.gov/articlerender.fcgi?artid=508685\&tool=pmcentrez\&rendertyp $\mathrm{e}=\mathrm{abstract}$

Lopez-Bergami, P., Huang, C., Goydos, J. S., Yip, D., Bar-Eli, M., Herlyn, M., Smalley, K. S. M., et al. (2007). Rewired ERK-JNK signaling pathways in melanoma. Cancer Cell, 11(5), 447460. Retrieved from http://www.pubmedcentral.nih.gov/articlerender.fcgi?artid=1978100\&tool=pmcentrez\&renderty $\mathrm{pe}=\mathrm{abstract}$

Mansukhani, A., Bellosta, P., Sahni, M., \& Basilico, C. (2000). Signaling by Fibroblast Growth Factors (Fgf) and Fibroblast Growth Factor Receptor 2 (Fgfr2)-Activating Mutations Blocks Mineralization and Induces Apoptosis in Osteoblasts. The Journal of Cell Biology, 149(6), 12971308. The Rockefeller University Press. Retrieved from http://www.pubmedcentral.nih.gov/articlerender.fcgi?artid=2175120\&tool=pmcentrez\&renderty pe $=$ abstract

Marie, P. J. (2003). Fibroblast growth factor signaling controlling osteoblast differentiation. Gene, 316, 23-32. Retrieved from http://linkinghub.elsevier.com/retrieve/pii/S0378111903007480

Matsuguchi, T., Chiba, N., Bandow, K., Kakimoto, K., Masuda, A., \& Ohnishi, T. (2009). JNK activity is essential for Atf4 expression and late-stage osteoblast differentiation. Journal of bone and mineral research the official journal of the American Society for Bone and Mineral Research, 24(3), 398-410. Retrieved from http://www.ncbi.nlm.nih.gov/entrez/query.fcgi? $\mathrm{cmd}=$ Retrieve \&db=PubMed\&dopt=Citation\&list _uids $=19016586$ 
McHugh, T., Wyers, M., \& King, E. (2007). MRI characterization of the glenohumeral joint in Apert syndrome. Pediatric Radiology.

De Mendonça Costa, A., Bueno, Daniela F, Martins, M. T., Kerkis, I., Kerkis, A., Fanganiello, Roberto D, Cerruti, H., et al. (2008). Reconstruction of large cranial defects in nonimmunosuppressed experimental design with human dental pulp stem cells. The Journal of craniofacial surgery, 19(1), 204-210. Retrieved from http://www.ncbi.nlm.nih.gov/pubmed/18216690

Mestas, J., \& Hughes, C. C. W. (2004). Of mice and not men: differences between mouse and human immunology. Journal of immunology (Baltimore, Md. : 1950), 172(5), 2731-8. Retrieved from http://www.ncbi.nlm.nih.gov/pubmed/14978070

Miki, T., Bottaro, D. P., Fleming, T. P., Smith, C. L., Burgess, W. H., Chan, A. M., \& Aaronson, S. A. (1992). Determination of ligand-binding specificity by alternative splicing: two distinct growth factor receptors encoded by a single gene. Proceedings of the National Academy of Sciences of the United States of America, 89(1), 246-250. Retrieved from http://www.pubmedcentral.nih.gov/articlerender.fcgi?artid=48213\&tool=pmcentrez\&rendertype $=$ abstract

Miraoui, H., Oudina, K., Petite, H., Tanimoto, Y., Moriyama, K., \& Marie, P. J. (2009). Fibroblast growth factor receptor 2 promotes osteogenic differentiation in mesenchymal cells via ERK1/2 and protein kinase C signaling. The Journal of Biological Chemistry, 284(8), 4897-904. doi:10.1074/jbc.M805432200

Miura, T., Perlyn, C. a, Kinboshi, M., Ogihara, N., Kobayashi-Miura, M., Morriss-Kay, Gillian M, \& Shiota, K. (2009). Mechanism of skull suture maintenance and interdigitation. Journal of anatomy, 215(6), 642-55. doi:10.1111/j.1469-7580.2009.01148.x

Moloney, D. M., Slaney, S. F., Oldridge, M., Wall, S A, Sahlin, P., Stenman, G., \& Wilkie, A. O. (1996). Exclusive paternal origin of new mutations in Apert syndrome. Nature Genetics, 13(1), 48-53.

Naski, M. C., \& Ornitz, D M. (1998). FGF signaling in skeletal development. Frontiers in Bioscience, 3(4), 781-794. Informa UK Ltd UK. doi:10.3109/15513819809168795

Ninomiya, J. T., Tracy, R. P., Calore, J. D., Gendreau, M. A., Kelm, R. J., \& Mann, K. G. (1990). Heterogeneity of human bone. Journal of bone and mineral research the official journal of the American Society for Bone and Mineral Research, 5(9), 933-938.

Oldridge, M., Zackai, E. H., McDonald-McGinn, D. M., Iseki, S., Morriss-Kay, G M, Twigg, S. R., Johnson, D, et al. (1999). De novo alu-element insertions in FGFR2 identify a distinct pathological basis for Apert syndrome. The American Journal of Human Genetics, 64(2), 446461. Retrieved from http://www.pubmedcentral.nih.gov/articlerender.fcgi?artid=1377754\&tool=pmcentrez\&renderty pe $=$ abstract 
Opperman, L A. (2000). Cranial sutures as intramembranous bone growth sites. Developmental dynamics an official publication of the American Association of Anatomists, 219(4), 472-485. Retrieved from http://www.ncbi.nlm.nih.gov/pubmed/11084647

Opperman, Lynne A, Sweeney, T. M., Redmon, J., Persing, J. A., \& Ogle, R. C. (1993). Tissue interactions with underlying dura mater inhibit osseous obliteration of developing cranial sutures. Developmental dynamics an official publication of the American Association of Anatomists, 198(4), 312-22. doi:10.1002/aja.1001980408

Ornitz, D M. (2000). FGFs, heparan sulfate and FGFRs: complex interactions essential for development. BioEssays news and reviews in molecular cellular and developmental biology, 22(2), 108-112. Am Soc Microbiol. Retrieved from http://www.ncbi.nlm.nih.gov/pubmed/10655030

Ornitz, David M, \& Itoh, Nobuyuki. (2001). Fibroblast growth factors. Genome Biology, 2(3), reviews3005.1-reviews3005.12. BioMed Central. Retrieved from http://www.ncbi.nlm.nih.gov/pubmed/10687947

Orr-Urtreger, A., Bedford, M. T., Burakova, T., Arman, E., Zimmer, Y., Yayon, A., Givol, D., et al. (1993). Developmental localization of the splicing alternatives of fibroblast growth factor receptor-2 (FGFR2). Developmental Biology, 158(2), 475-486. Retrieved from http://www.ncbi.nlm.nih.gov/pubmed/8393815

Ozerdem, O. R., Anlatici, R., Bahar, T., Kayaselçuk, F., Barutçu, O., Tuncer, I., \& Sen, O. (2003). Roles of periosteum, dura, and adjacent bone on healing of cranial osteonecrosis. The Journal of craniofacial surgery, 14(3), 371-379; discussion 380-382.

Park, W. J., Theda, C., Maestri, N. E., Meyers, G. A., Fryburg, J. S., Dufresne, C., Cohen, M M, et al. (1995). Analysis of phenotypic features and FGFR2 mutations in Apert syndrome. The American Journal of Human Genetics, 57(2), 321-328. Retrieved from http://www.pubmedcentral.nih.gov/articlerender.fcgi?artid=1801532\&tool=pmcentrez\&renderty pe $=$ abstract

Passos-Bueno, M R, Richieri-Costa, A., Sertié, A L, \& Kneppers, A. (1998). Presence of the Apert canonical S252W FGFR2 mutation in a patient without severe syndactyly. Journal of Medical Genetics, 35(8), 677-679. Retrieved from

http://www.pubmedcentral.nih.gov/articlerender.fcgi?artid=1051397\&tool=pmcentrez\&renderty pe $=$ abstract

Passos-Bueno, M R, Sertié, A L, Zatz, M., \& Richieri-Costa, A. (1997). Pfeiffer mutation in an Apert patient: how wide is the spectrum of variability due to mutations in the FGFR2 gene? American Journal of Medical Genetics. Wiley Online Library. Retrieved from http://onlinelibrary.wiley.com/doi/10.1002/(SICI)1096-8628(19970808)71:2<243::AIDAJMG27>3.0.CO;2-D/abstract 
Passos-Bueno, M., Sertie, A., Jehee, F., Fanganiello, R., \& Yeh, E. (2008). Genetics of craniosynostosis: genes, syndromes, mutations and genotype-phenotype correlations.

Craniofacial sutures: development, disease and treatment, 12, 107-143. Karger. Retrieved from http://books.google.com/books?hl=en\&amp;lr=\&amp;id=Z59zHPG711gC\&amp;oi=fnd\&amp;pg =PA107\&amp; $\mathrm{dq}=$ Genetics+of+Craniosynostosis:+Genes, + Syndromes, + Mutations+and+Genot ype-Phenotype+Correlations\&amp;ots=XqFsP_CjX\&amp;sig=zWLyP6XNE7FxjsjSU2Q2c0PwDB4

Patterson, K. I., Brummer, T., Brien, P. M. O., Daly, R. J., \& O’BRIEN, P. M. (2009). Dualspecificity phosphatases : critical regulators with diverse cellular targets. Biochemical journal, 418(2009), 475-489. Portland Press. doi:10.1042/BJ20082234

Posnick, J. C., Armstrong, D., \& Bite, U. (1995). Crouzon and Apert syndromes: intracranial volume measurements before and after cranio-orbital reshaping in childhood. Plastic and Reconstructive Surgery, 96(3), 539-548.

Renier, D., Arnaud, E., Cinalli, G., Marchac, D., Brunet, L., Sebag, G., Sainte-Rose, C., et al. (1996). Mental prognosis of Apert syndrome. Archives of Pediatrics, 3(8), 752-760.

Roth, D. A., Bradley, J. P., Levine, J. P., McMullen, H. F., McCarthy, J. G., \& Longaker, M T. (1996). Studies in cranial suture biology: part II. Role of the dura in cranial suture fusion. Plastic and Reconstructive Surgery, 97(4), 693-699.

Scadden, D. T. (2006). The stem-cell niche as an entity of action. Nature, 441(7097), 1075-9. doi:10.1038/nature04957

Schlessinger, J, Plotnikov, A. N., Ibrahimi, O. A., Eliseenkova, A. V., Yeh, B. K., Yayon, A., Linhardt, R J, et al. (2000). Crystal structure of a ternary FGF-FGFR-heparin complex reveals a dual role for heparin in FGFR binding and dimerization. Molecular Cell, 6(3), 743-750.

Retrieved from http://www.ncbi.nlm.nih.gov/pubmed/11030354

Shaul, Y. D., \& Seger, R. (2007). The MEK/ERK cascade: from signaling specificity to diverse functions. Biochimica et biophysica acta, 1773(8), 1213-26. doi:10.1016/j.bbamcr.2006.10.005

Shukla, V., Coumoul, X., Wang, R.-hong, Kim, H.-seok, \& Deng, C.-xia. (2007). RNA interference and inhibition of MEK-ERK signaling prevent abnormal skeletal phenotypes in a mouse model of craniosynostosis. Nature Genetics, 39(9), 1145-1150. doi:10.1038/ng2096

Slater, B. J., Lenton, K. A., Kwan, M. D., Gupta, D. M., Wan, D. C., \& Longaker, Michael T. (2008). Cranial sutures: a brief review. Plastic and Reconstructive Surgery, 121(4), 170e-8e. Retrieved from http://www.ncbi.nlm.nih.gov/pubmed/18349596

Squier, C. A., Ghoneim, S., \& Kremenak, C. R. (1990). Ultrastructure of the periosteum from membrane bone. Journal of Anatomy, 171, 233-239. Retrieved from http://www.ncbi.nlm.nih.gov/pubmed/2081707 
Su, N., Sun, Q., Li, Can, Lu, X., Qi, H., Chen, S., Yang, J., et al. (2010). Gain-of-function mutation in FGFR3 in mice leads to decreased bone mass by affecting both osteoblastogenesis and osteoclastogenesis. Human Molecular Genetics, 19(7), 1199-1210. Oxford University Press. Retrieved from http://www.ncbi.nlm.nih.gov/pubmed/20053668

Tolarova, M. M., Harris, J. A., Ordway, D. E., \& Vargervik, K. (1997). Birth prevalence, mutation rate, sex ratio, parents' age, and ethnicity in Apert syndrome. American Journal of Medical Genetics, 72(4), 394-398.

Trueb, B., Zhuang, L., Taeschler, S., \& Wiedemann, M. (2003). Characterization of FGFRL1, a novel fibroblast growth factor (FGF) receptor preferentially expressed in skeletal tissues. The Journal of Biological Chemistry, 278(36), 33857-33865. Retrieved from http://www.ncbi.nlm.nih.gov/pubmed/12813049

Wang, Y., Sun, M., Uhlhorn, V. L., Zhou, X., Peter, I., Martinez-Abadias, N., Hill, C. A., et al. (2010). Activation of p38 MAPK pathway in the skull abnormalities of Apert syndrome Fgfr2+P253R mice. BMC Developmental Biology, 10, 22. BioMed Central. Retrieved from http://www.pubmedcentral.nih.gov/articlerender.fcgi?artid=2838826\&tool=pmcentrez\&renderty pe $=$ abstract

Wang, Y., Xiao, R., Yang, F., Karim, B. O., Iacovelli, A. J., Cai, J., Lerner, C. P., et al. (2002). Abnormalities in cartilage and bone development in the Apert syndrome FGFR2 + / S252W mouse. Development. doi:10.1242/dev.01914

Wilkie, A. O. (1997). Craniosynostosis: genes and mechanisms. Human Molecular Genetics, 6(10), 1647-1656. Retrieved from http://www.ncbi.nlm.nih.gov/pubmed/9300656

Wilkie, A. O. M., Byren, J. C., Hurst, J. a, Jayamohan, J., Johnson, David, Knight, S. J. L., Lester, T., et al. (2010). Prevalence and complications of single-gene and chromosomal disorders in craniosynostosis. Pediatrics, 126(2), e391-400. doi:10.1542/peds.2009-3491

Wilkie, A. O., \& Morriss-Kay, G M. (2001). Genetics of craniofacial development and malformation. Nat Rev Genet, 2, 458-468. doi:10.1038/35076601

Wilkie, A. O., Slaney, S. F., Oldridge, M., Poole, M. D., Ashworth, G. J., Hockley, A. D., Hayward, R. D., et al. (1995). Apert syndrome results from localized mutations of FGFR2 and is allelic with Crouzon syndrome. Nature Genetics, 9(2), 165-172.

Yang, F., Wang, Y., Zhang, Z., Hsu, B., Jabs, Ethylin Wang, \& Elisseeff, J. H. (2008). The study of abnormal bone development in the Apert syndrome Fgfr2+/S252W mouse using a 3D hydrogel culture model. Bone, 43(1), 55-63. Retrieved from http://www.ncbi.nlm.nih.gov/pubmed/17707711

Yeh, E. (2011). Estudo da contribuição molecular e celular do periósteo na craniossinostose da síndrome de Apert. Universidade de São Paulo. 
Yeh, E., Atique, R., Ishiy, F., Fanganiello, R., Alonso, N., Matsushita, H., \& Passos-bueno, M. R. (2011). FGFR2 Mutation Confers a Less Drastic Gain of Function in Mesenchymal Stem Cells Than in Fibroblasts. Stem Cell Reviews and Reports. doi:10.1007/s12015-011-9327-6

Zollikofer, C. P. E., \& Ponce De León, M. S. (2010). The evolution of hominin ontogenies. Seminars in cell developmental biology, 21(4), 441-452. Retrieved from http://www.ncbi.nlm.nih.gov/pubmed/19900572 


\section{Capítulo III}

\section{CONTROL AND EFFECTS OF THE ALTERED EXPRESSION OF DUSP2 IN PERIOSTEUM DERIVED FIBROBLASTS FROM SYNDROMIC CRANIOSYNOSTOSIS PATIENTS.}

Rodrigo Atique

Erika Yeh

Nivaldo Alonso

Hamilton Matsushita

Katia Maria da Rocha

Maria Rita Passos-Bueno 


\section{Abstract}

Craniosynostosis are congenital craniofacial abnormalities characterized by premature closure of the cranial sutures. The prevalence of craniosynostosis is 1 for every 2500 live births. One of the most severe forms of Craniosynostosis is Apert Syndrome (AS), characterized by premature fusion of the coronal sutures and symmetrical syndactyly of the hand and feet. AS is caused by gain of function mutations in the FGFR2 gene (p.S252W and p.P253R) that induces loss of specificity of the receptor for its ligands, leading to abnormal activation of the receptor. When dimerized, FGFR2 leads to the activation of signaling transduction pathways like MEK/ERK and PI3-K. Previous works have shown that DUSP2, a dual specific phosphatase, is more expressed in AS periosteum fibroblasts than in controls. DUSP2 is capable of dephosphorylate members of the MAPK family like p-JNK. We show in this work that FGFR2 is regulating the protein levels of DUSP2 in patients and controls, and that this regulation, however, is being held by different pathways in patients and controls. We have also demonstrated that DUSP2 negatively regulates the phosphorylation of JNK. 


\section{Resumo}

Craniossinostoses são anomalias craniofaciais congênitas caracterizadas pelo fechamento precoce das suturas cranianas, cuja prevalência é de 1 para cada2500 nascidos vivos. Uma das formas mais graves de craniossinostose é a Síndrome de Apert (SA), que leva ao fechamento precoce das suturas coronais e sindactilia simétrica das mãos e dos pés. A SA é causada por mutações do tipo ganho de função no gene FGFR2 (p.S252W ou p.P253R) que levam a perda de especificidade do receptor por seus ligantes e causam a ativação exacerbada do mesmo. FGFR2, quando dimerizado, leva a ativação de vias de sinalização, dentre elas MEK/ERK e PI3-K. Trabalhos anteriores mostraram que o gene para a fosfatase DUSP2 está mais expresso em fibroblastos do periósteo de pacientes portadores da SA do que em controles. DUSP2 é capaz de desfosforilar membros das MAPKs, dentre estes p-JNK. Nesse trabalho mostramos que a ativação de FGFR2 regula os níveis proteicos de DUSP2 tanto em pacientes quanto em controles, porém por vias diferentes em cada caso, e que DUSP2 está regulando negativamente a fosforilação de JNK. 


\section{Introduction}

Craniosynostosis are a common congenital craniofacial abnormality with an estimated frequency of 1 in every 2500 live births (Cohen Jr. et al., 2000; M. Passos-Bueno et al., 2008). The term craniosynostosis refers to the process of premature fusion of the neurocranium sutures. The fusion starts at a point and spreads along the suture, and may affect one, multiple or all the cranial sutures. The onset of the premature fusion may be before or after birth. In the presence of craniosynostosis, the skull cannot expand perpendicular to the closed suture, and thus compensate by growing in the perpendicular direction of the open sutures, allowing enough space for the growing brain, resulting in altered skull shape and, in abnormal facial features (Cohen Jr. et al., 2000). Craniosynostosis are etiologically and pathologically heterogeneous diseases, but, according to genetic studies they can be classified as nonsyndromic (without other primary malformations) or syndromic (with other primary malformations)(Cohen Jr. et al., 2000; M. Passos-Bueno et al., 2008; A. O. Wilkie et al., 2001)

Apert syndrome (AS), a rare and the most severe syndromic craniosynostosis, is characterized by early fusion of the coronal sutures, midface hypoplasia and symmetrical syndactyly of the hand and feet (Cohen Jr. et al., 2000). It is caused by one of two mutations in the FGFR2 gene: p.S252W and p.P253R(Lajeunie et al., 1999; M R Passos-Bueno et al., 1997; A. O. Wilkie et al., 1995). These mutations cause the loss of specificity of the receptors for its ligands, increasing its affinity by virtually all the FGFs (O. Ibrahimi, Fuming Zhang, et al., 2004). When bound to the FGF and an heparan sulfate molecule the receptor dimerizes and autophosphorylates, leading to the activation of three main downstream pathways: MEK/ERK, PI3-K (and the phosphorylation of its downstream target AKT) and PLC (Lemmon et al., 2010). The excessive and repetitive closure of the coronal suture after cranial surgical intervention (Foster et al., 2008; David Johnson, 2003), a mandatory procedure for the rehabilitation of these patients, makes this invasive technique needed for more than 10 times from birth until adulthood 
(Cohen Jr. et al., 2000). The premature suture fusion and the resynostosis process after surgical interventions are not likely the result of alterations in one particular cell type as osteoblasts but the result of perturbations in signaling and in interactions between different cell types and tissues of the cranial suture complex (Slater et al., 2008). The mechanisms involved in the suture resynostosis after birth are still poorly understood, but we have shown previously that fibroblasts of the periosteum of AS patients play an important role in these processes (E. Yeh et al., 2011) .

Fanganiello et al., 2007 compared the transcriptome of fibroblasts from Apert syndrome patients versus control individuals, and found, among 263 differentially expressed genes, a highly significant increased expression of the DUSP2 gene (2.25 fold change). DUSP2 is a dual specific phosphatase, a large heterogenous group that is characterized by their unique ability to dephosphorylate its substrate at both tyrosine and serine/threonine residues. DUSP2 is a member of the best characterized subgroup within DUSPs, MKP (mitogen-activated protein kinase phosphatases).MKP contains 10 proteins that can dephosphorylate MAPK at both phosphothreonine and phosphotyrosine residues simultaneously within the MAPK TXY (Thr-Xaa-Tyr) activation motif, and thereby act as antagonists of associated signaling cascades (Patterson et al., 2009). The relevance of this class of MKPs to craniosynostosis has also been suggested by the presence of coronal synostosis in the knockout mouse for Dusp6 (Chaoying Li et al., 2007).

In vitro studies of DUSP2 deficient mast cells have shown that DUSP2 acts as a negative regulator of the c-Jun $\mathrm{N}$-terminal kinases (JNK) activity (Jeffrey et al., 2006). JNKs, originally identified as stress-activated protein kinases (SAPKs) in the livers of the cycloheximide challenged rats, were renamed to emphasize their role in phosphorylation and activation of transcription factor c-jun. The JNKs are strongly activated in response to cytokines, UV irradiation, growth factor deprivation, DNA damaging agents and, to lesser extent, by stimulation of some GPCRs, serum, and growth factors 
(Krishna et al., 2008). JNK has also been involved with osteogenic differentiation by the demonstration that p-JNK modulates the response of pre-osteoblasts to BMP-2 (Guicheux et al., 2003; H. Liu et al., 2010; E. Yeh et al., 2011). JNK seems also to be involved in the increased osteogenic potencial of Apert fibroblasts (Yeh et al.., 2011). It is thus possible that deregulation of DUSP2 and JNK are involved with the aberrant fibroblast Apert phenotype.

Given the above considerations, our objective in this paper is to ascertain whether deregulation of DUSP2 results in altered JNK phosphorylation and, if so, determine through which pathway the increased activation of FGFR2 $^{\mathrm{S} 252 \mathrm{~W}}$ in AS fibroblasts regulates DUSP2 and p-JNK

\section{Results}

a) Total and phosphorylated JNK (p-JNK) levels in AS fibroblasts

We first assessed the p-JNK levels from periosteal fibroblasts of 6 AS patients, 7 controls and 5 Crouzon syndrome (CS) patients, another syndromic coronal craniosynostosis caused by FGFR2 mutations. We also measured the total JNK levels for 3 cultures of each group. The total protein extraction was performed after 24 hour starvation. The $\mathrm{p}$-JNK/JNK ratio was determined using the obtained values for the samples that were present at both experiments. 
A

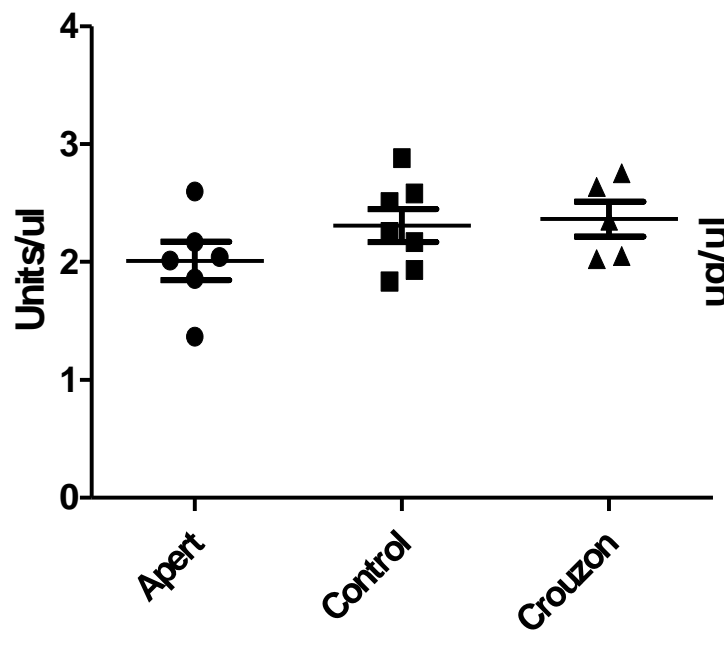

B

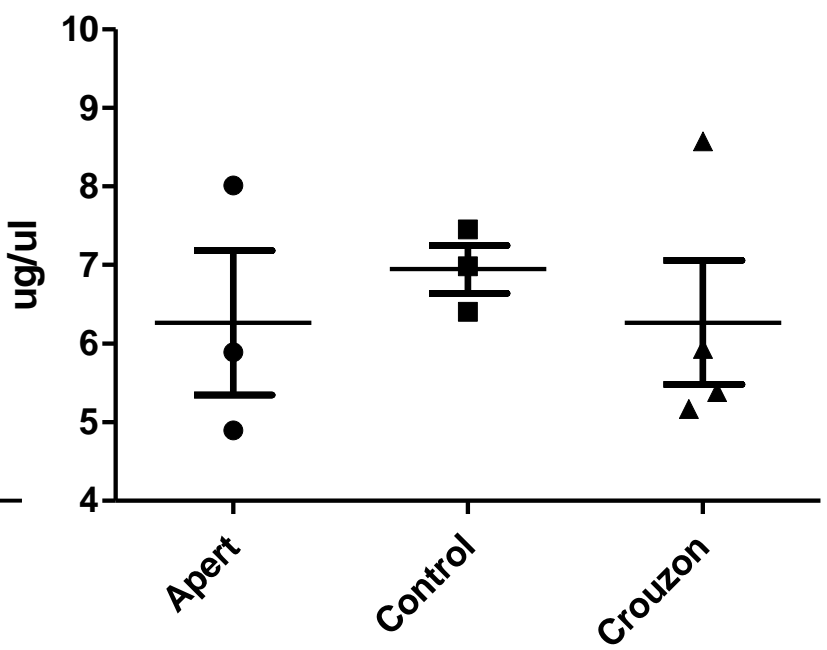

C p-JNK/JNK

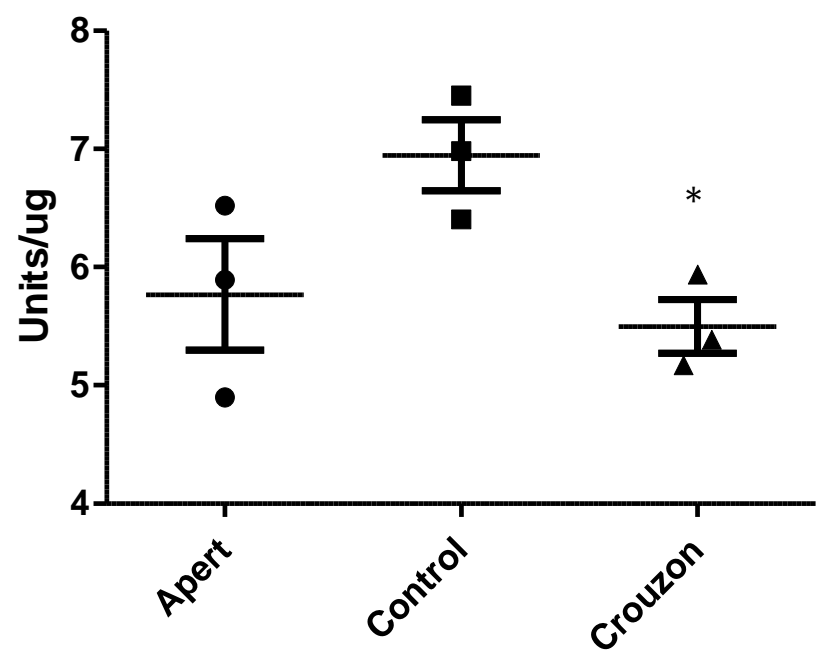

Figure 1: Protein concentration of $p$-JNK (A), total JNK (B) and the ratio between total JNK and $p$-JNK (C) from periosteal fibroblasts of AS patients, controls and CS patients. $(*: p<0,05$ when compared to the control group)

As we can see in Figure 1, the AS, Control and CS groups had similar levels of p-JNK (Fig. 1A), however total JNK (Fig.1B) varied greatly in the samples. Given the low number of AS patients tested, we lack the statistical power to tell that there is a difference between the AS, Control and CS groups, yet the majority of the AS and CS patients were at least 2-fold the standard deviation below the average of the control group, also the variance between the samples of the Control group was smaller when compared 
to the variance of the AS and CS samples, which could indicate that the mutation could be destabilizing the pathways involved in the control of total JNK levels. The P-JNK/JNK ratio (Fig. 1C) was statistically different between the Control and Crouzon groups, the Apert group exhibited once again great variance, and therefore, no stastistical difference to the Control and Crouzon groups.

b) Mechanisms leading to JNK variability

In order to test if culture conditions could be responsible for the variation and lack of statistical differences between JNK levels in AS and Control cultures we performed quantitative Real Time PCR of total cDNA from AS and Control Fibroblasts in both starved and non-starved conditions (Figure 2).

\section{JNK}

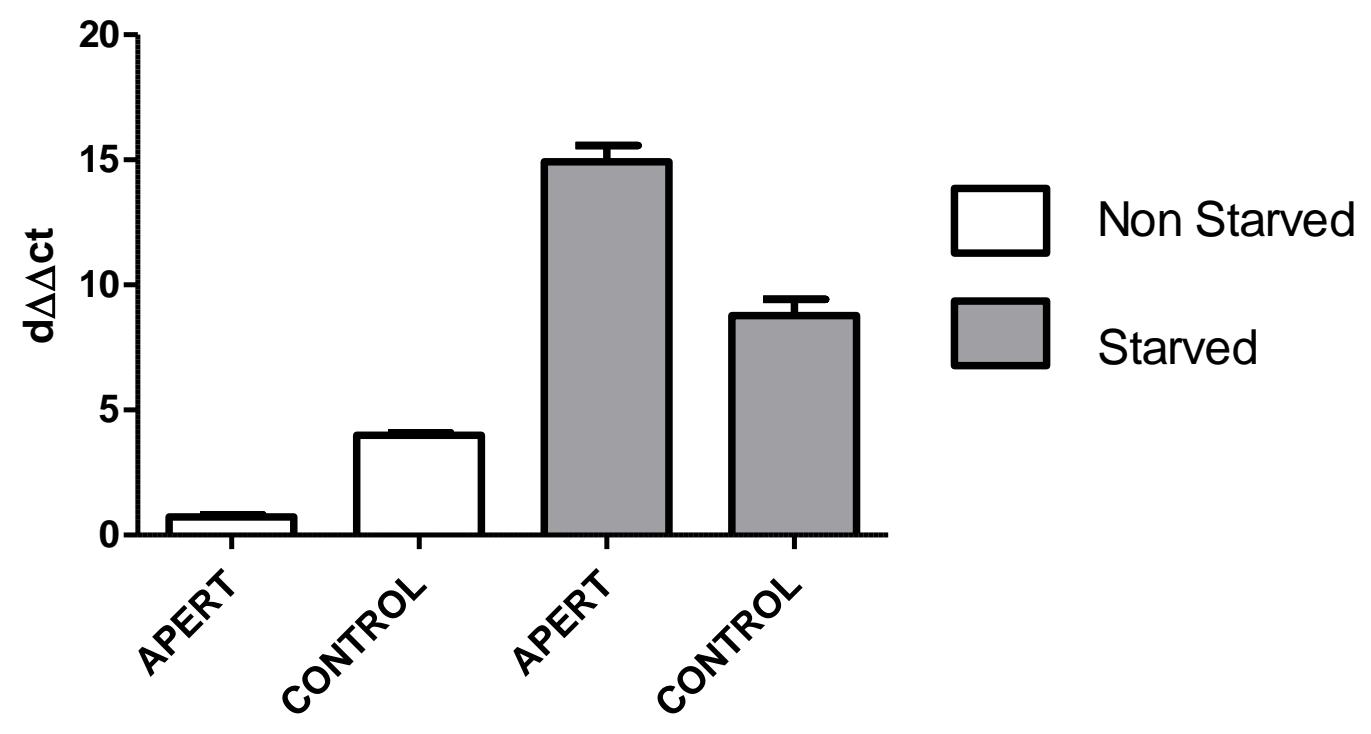

Figure 2: Relative expression levels of Apert syndrome and Control fibroblasts on starved and non-starved conditions. Bars represent Standard Error. All groups differ significantly from each other $(P<0,05)$

Starvation seems to increase the expression levels of JNK on both AS and Control groups. The relative levels, however, are opposite on both conditions, in the non-starved treatment the Apert have five times less JNK expression than the controls; in the starved cultures, the Apert cells exhibit twice more JNK than the controls. The greater response of the AS fibroblasts to the absence of growth factors could 
be indicative that FGFR2 is mediating the modulation of JNK expression in these cells. Also, the increase in JNK expression exhibited when the fibroblasts are starved could be saturating the amount of total JNK available in both AS and Control samples (Figure 1B), which could explain the small difference between the samples averages.

c) Regulation of DUSP2 and P-JNK by FGFR2 pathways

To determine how the different pathways activated by FGFR2 are acting in the modulation of $p$ JNK, fibroblasts were starved for 24 hours in order to avoid the activation of the signal transduction pathways by the growth factor and cytokines contained in the FBS (fetal bovine serum). After starvation the cells were treated with FGF-2 and inhibitors for the MEK/ERK and PI3-K pathways (U0126 and Wortmannin, respectively),. The protein extractions were performed 15 minutes and 2 hours after the treatment in order to evaluate if possible observed differences were due to post transductional modification or if it required at least one step of transcription.

Figure 3 shows the obtained values of $p$-JNK by the different treatments. The control cells exhibited a 2-fold increase in phosphorylation over the AS at the not treated (NT) condition. The FGF-2 treatment increased $\mathrm{p}-\mathrm{JNK}$ in the AS cultures and decreased it on the control cultures, both on a time dependent manner. The AS and control cultures responded analogously to the inhibition of the PI3-K pathway. On both cases the p-JNK levels increased on both 15 minutes and 2 hours treatments. The MEK/ERK pathway inhibition increased the phosphorylation levels at the 15 minutes treatment on both cultures. On the other hand, after the 2 hour treatment, the $p$ - JNK levels decreased in AS fibroblasts and increased in Control. But in both cases, after 2 hours, p-JNK levels in MEK inhibition were comparable to those in NT state. The aforementioned results indicate that the PI3-K pathway is involved with the modulation of $\mathrm{p}-\mathrm{JNK}$ by FGFR2, since long term inhibition of PI3K sustained the high levels of $p$ JNK in AS and Control fibroblasts. 


\section{Apert}
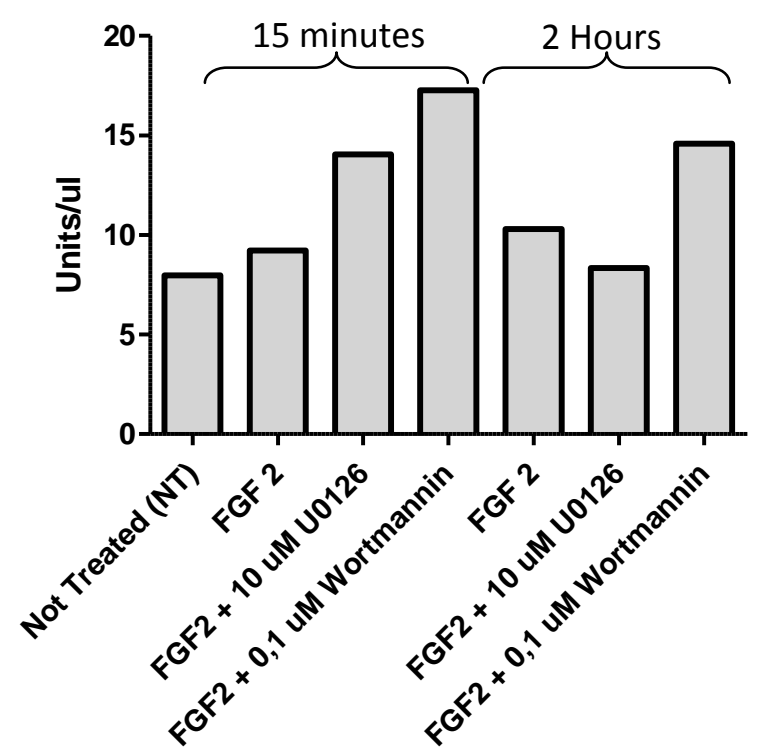

Control
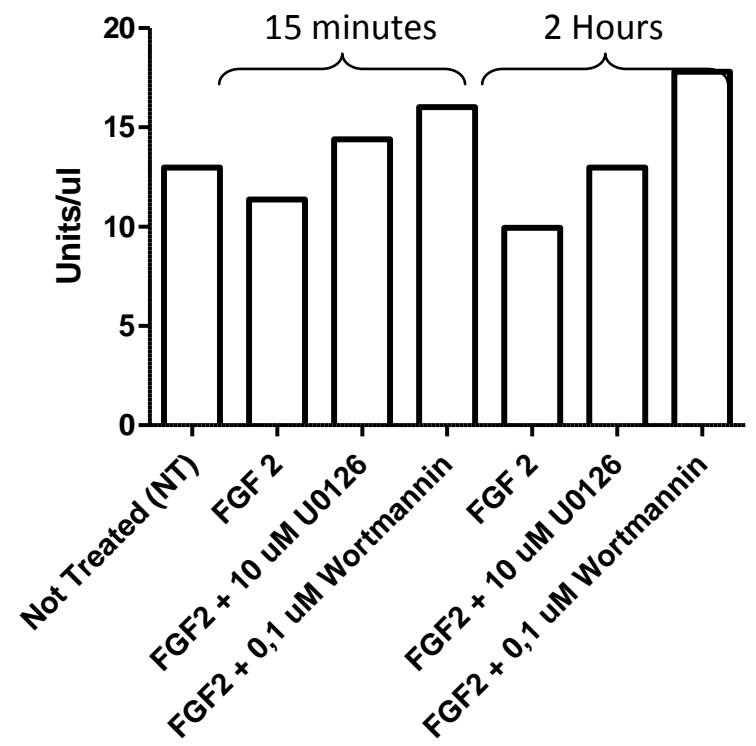

Figure 3: Phosphorylation levels of JNK on AS and Control cultures. After 24 hours starvation, the cells were concurrently treated with 30ng/ml of FGF-2 and one of the inhibitors of MEK or PI3-K (U0126 and Wortmannin, respectively). The total protein lysate was obtained after 15 minutes or 2 hours of treatment.

To verify how DUSP2 is being regulated by the activation of FGFR2, we performed western blotting experiments on the same conditions used on the previous experiments, probing for the relative protein levels of DUSP2. Also, to assess how the MEK/ERK and PI3-K pathways are responding to the various treatments we also determined the relative protein levels of $p$-ERK and $p$-AKT. 

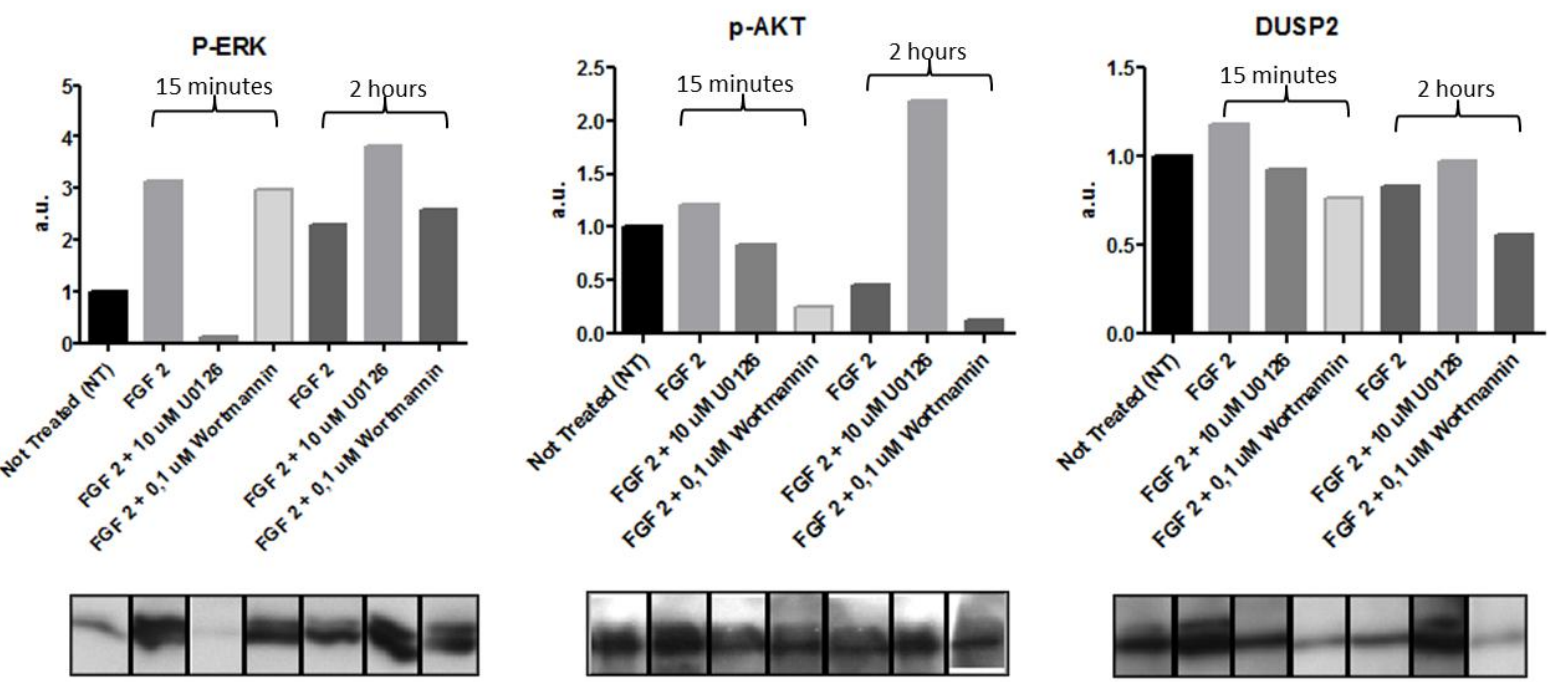

CONTROL
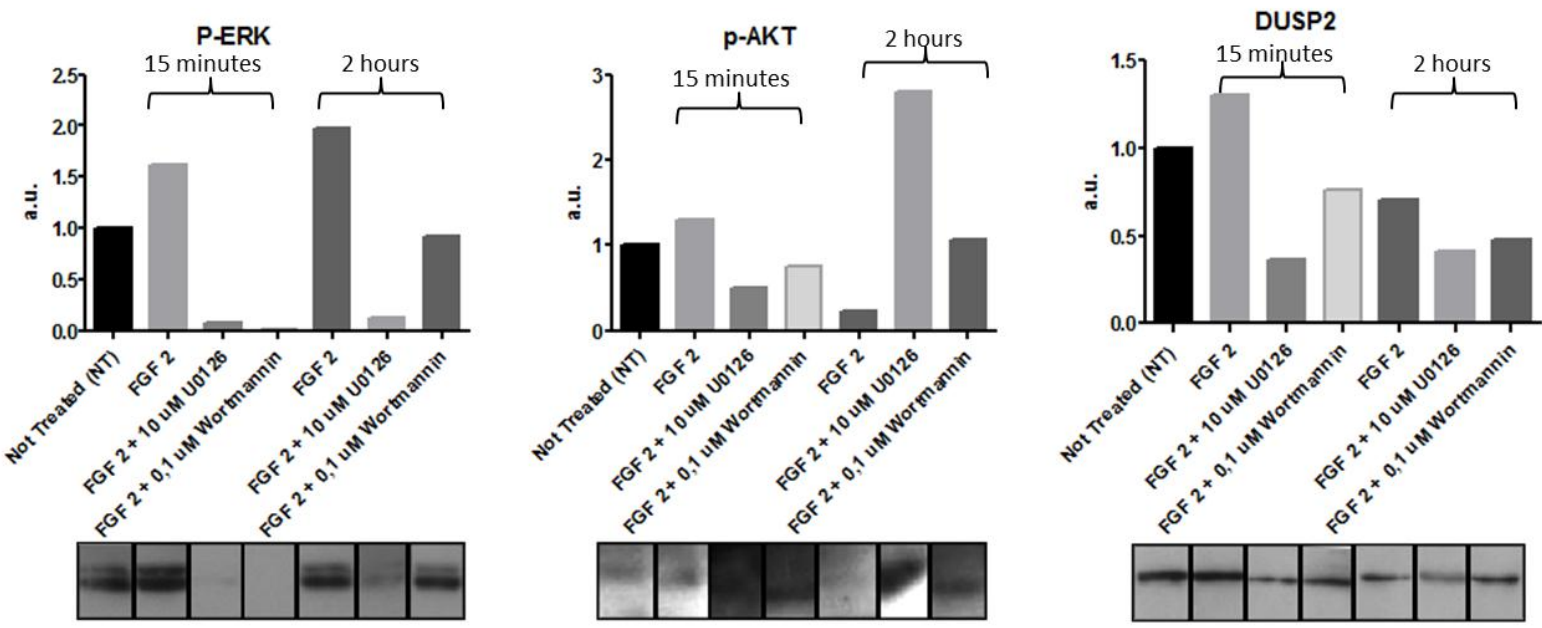

Figure 4: Densiometry relative levels obtained by Western Blotting for p-ERK, p-AKT and DUSP2 proteins. Cells were starved for 24 hours, after starvation the cells were concurrently treated with $30 \mathrm{ng} / \mathrm{ml}$ of FGF-2 and one of the inhibitors of MEK or PI3-K (U0126 and Wortmannin). The total protein lysate was obtained after 15 minutes or 2 hours of treatment. The values were normalized by the value obtained for the endogenous marker, $\beta$-actin, and the fold change was calculated by considering the "not treated" samples value as 1 .

The proteic levels of DUSP2 increased by the FGF-2 stimulus for 15 minutes and seem to respond more prominently to the inhibition of PI3-K pathway in the AS culture and to the MEK inhibition in the Controls, exhibiting a decrease of the proteic levels of DUSP2. The DUSP2 levels also decreased with the inhibition of MEK in AS fibroblasts and to the inhibition of PI3-K in Control cells, however the 
variation is much less drastic, only half of the decrease of the DUSP2 levels as compared to the inhibition of PI3-K.

The p-ERK levels were greatly diminished by its specific inhibitor in both Apert and Control fibroblasts at 15 minutes of treatment, at 2 hours of treatment. Nevertheless, we observed augmented p-ERK in the AS fibroblasts when compared to the FGF-2 treatment at the same time point, that could be due to a exacerbated rebound effect, in which the pathway adapts itself to the lack of signaling.

The PI3-K pathway responded on a similarly on both Apert and Control, the only difference was the response for the inhibition of the PI3-K activity for 2 hours, in which the control group had increased p-AKT levels when compared to the FGF-2 treatment for the same time.

Overall the ERK signaling in Apert cells seems to be less sensitive to the cross-talk between PI3-k and ERK pathways as we can see that 15 minutes and 2 hours inhibition of PI3-K in Control fibroblasts decreases the activation of ERK, but the same does not happen in Apert fibroblasts. To test whether there is correlation between the DUSP2 proteic levels and the activation of the different pathways, we plotted the relative phosphorylation levels against the protein levels of DUSP2 (Figure 5). 

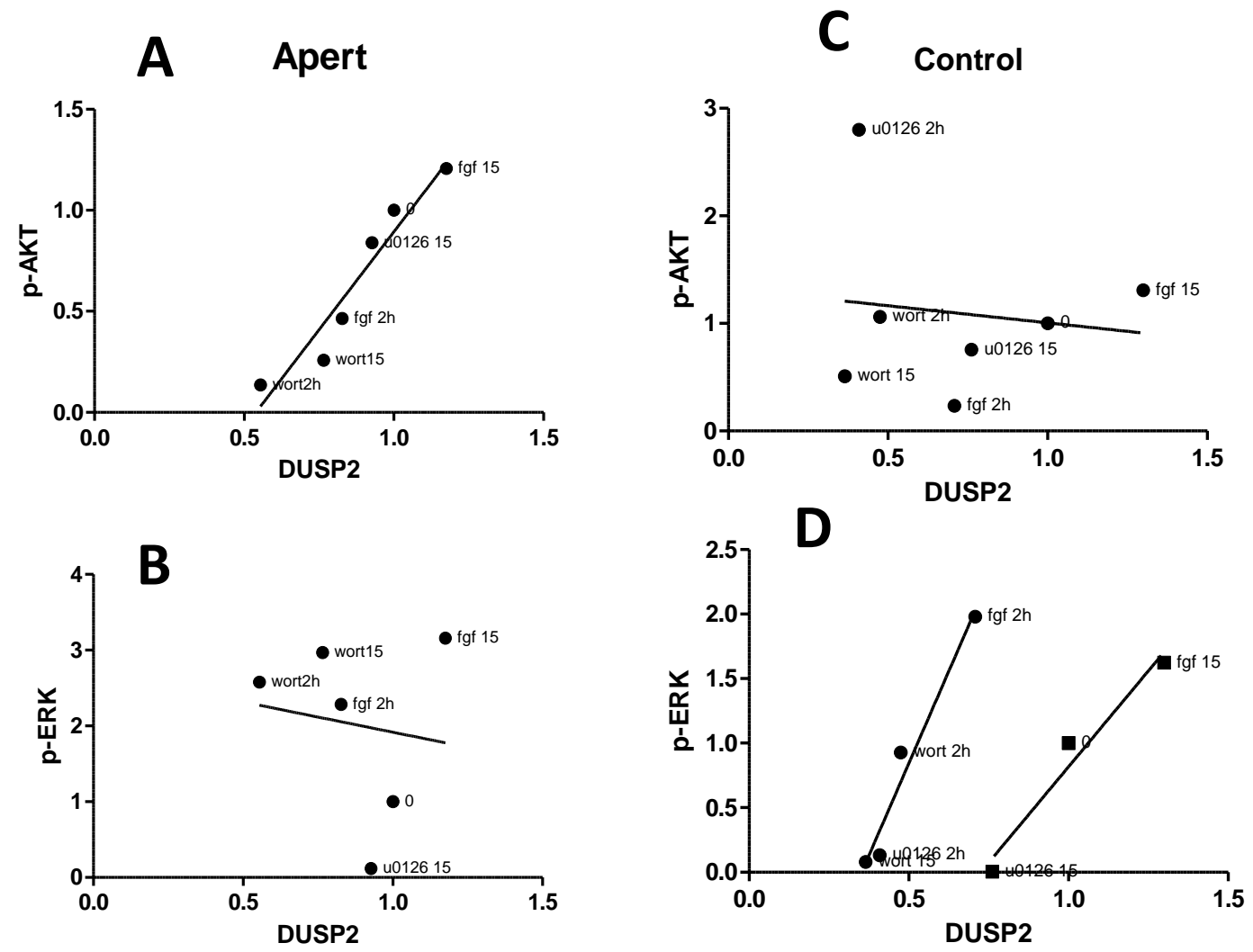

Figure 5: Scatter plots of the $p$ - ERK and p-AKT against the protein levels of DUSP2 on Apert and Control. The $\mathrm{R}^{2}$ values for the linear regression are: A: 0.9215; B:0.01992; C:0.01690 and D:0.9618 e 0.9619.

Figure 5 shows that there is a positive linear relationship between p-AKT and DUSP2 in the Apert fibroblasts and between p-ERK and DUSP2 in the control group. The p-ERK and DUSP2 levels correlation, however, seems to fit more precisely a double linear correlation than a single one. To verify if the same proportionality exists between DUSP2 and p-JNK, the same approach was used (figure 6). 

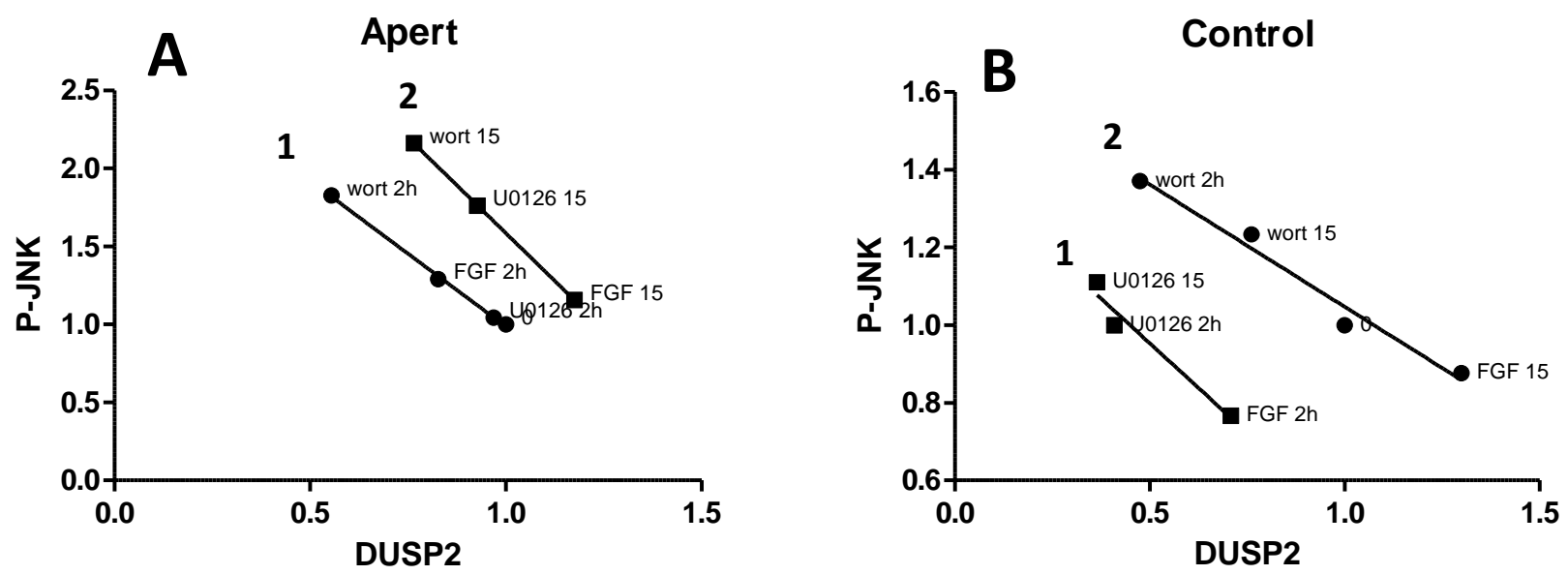

Figure 6: Scatter plots of fold change of DUSP2 protein levels versus Phospho-JNK levels for Apert fibroblasts (A) and Control fibroblasts (B). The values of $R^{2}$ for the linear regressions are: A: $1-0,9985,2-1,000 ; B: 1-0,9741,2-$ 0,9599 .

As in the linear correlation between DUSP2 and p-ERK on the control fibroblasts, here we observed two distinct linear tendencies in which the DUSP2 protein concentration raises without altering the $\mathrm{p}-\mathrm{JNK}$, but within each line, the DUSP2 levels are negatively correlated to the $\mathrm{p}$-JNK levels.

\section{Discussion}

The importance of signaling pathways downstream of FGFR2 in the pathology of Apert syndrome was previously demonstrated by SHUKLA et al., 2007. They successfully reversed the craniosynostosis of an Apert syndrome mouse model (S252W) by inhibiting the MEK/ERK pathway pharmacologically and by RNAi. These findings have opened the possibility of identification of potential drugs that could ameliorate the phenotype of these patients and highlight the importance of understanding the pathways involved with the Apert cellular phenotype.

In the present paper, we have aimed to verify if altered DUSP2 expression in FGFR2 mutated AS cells influences JNK pathway. In addition, we tested through which FGFR2 pathway, ERK or PI3K, leads to 
altered DUSP2 and p-JNK expression levels in AS cells. We hope that understanding these pathways can help elucidate the altered fibroblast phenotype in the presence of the FGFR2 S252W mutation.

Although we were not able to demonstrate that fibroblasts from the periosteum of Apert and Crouzon syndromes patients had different JNK phosphorylation levels, our data suggest that this pathway is disturbed in AS cells as a greater variance was observed in the presence of the S252W mutation. It has been demonstrated that growth factor deprivation increases JNK activation (Reviewed by KRISHNA; NARANG, 2008). Since our experiments were done on starved cells, the increase in phosphorylation by growth factor deprivation may be masking differences between the groups. Further experiments on non-starved cells are necessary to test this hypothesis. Our data also suggests that JNK phosphorylation is being controlled by different pathways in Apert and Control fibroblasts, PI3-K and MEK/ERK respectively.

The DUSP2 levels were increased on both AS and Control fibroblasts by the treatment with FGF2. Moreover, the inhibition of ERK and PI3-K pathways leads to alterations of the protein levels of DUSP2. Since FGF-2 binds to and activates all isoforms of FGFRs (except for FGFR2b)(O. A. Ibrahimi, F Zhang, et al., 2004; Lemmon et al., 2010) we can't determine for sure which of the FGFRs is responsible for the modulation of DUSP2 protein levels, however the fact that the S252W mutation alters the pathway responsible for this modulation indicates that FGFR2 is at least partially responsible for it.

So far the studies on Apert syndrome have concentrated on exploring the role of the MEK/ERK pathway on the pathophysiology of the disease(Shukla et al., 2007; Y. Wang et al., 2010), which is explained by the fact that this pathway is commonly associated with cellular differentiation (Eswarakumar et al., 2005; Krishna et al., 2008). The PI3-K pathway is generally downplayed as an important pathway in the Apert phenotype. It is usually described as mediator of programed cell death since it regulates several transcription factors associated with apoptosis, such as the FOXO family, BIM, 
p53, among others (Chalhoub et al., 2009).It is also overlooked because the FGFRs doesn't recruit PI3-K as efficiently as others RTKs (e.g.PDGFR). However, previous results on the literature and the data presented on this paper indicate that both MAPK and PI3K pathways play important roles on the pathophysiology of Apert Syndrome by regulating the protein levels of DUSP2. Some of the results of the ERK and PI3-K inhibition are puzzling: for example, the sudden increase in p-AKT levels observed after the control fibroblasts were treated with the PI3-K inhibitor and FGF-2 for 2 hours. It could be due to decreased PTEN activity, since PTEN is a phosphatase that acts as an antagonist of the PI3-K activity and is also responsible for the regulation of AKT phosphorylation (Chalhoub et al., 2009). Further experiments are needed to define the responsible factors for this observation.

Another interesting finding in our work is the existence of 2 linear correlations of DUSP2 by ERK and P-JNK by DUSP2. One of the possible explanations to this phenomenon is one characteristic of the MAPKs called hysteresis. Hysteresis is the name given to the capacity of complex systems of giving different responses to the same stimuli depending on its history (Kholodenko et al., 2009). The occurrence of hysteresis in the MAPKs is given by characteristics like positive and negative feedback loops, protein scaffolding, multi-layered processive phosphorylation and multi-site phosphorylation (Figure 7). This allows the system -the cell- to keep a memory of previous stimuli, in a way that, depending on the activation level obtained by these cells prior to the protein extraction, the output (the levels of DUSP2, p-ERK and p-JNK) given to the input (FGF-2 treatment) happen at 2 different intensities. This leads to a bistable model of activation of the MAPKs, which can be seen as a trigger-like behavior: depending on the level of activation of the pathway prior to the analysis we would see two different responses to the stimuli. This seems to be the case here, since this bistability is observed in the ERK pathway correlation with DUSP2 and in the correlation of DUSP2 and p-JNK, but not in the PI3-K /DUSP2 correlation. 
We thus have successfully demonstrated for the first time the involvement of DUSP2 in Apert syndrome and that DUSP2 regulates p-JNK in both Apert and Control fibroblasts. DUSP2 is usually described as a modulator of immune responses (Jeffrey et al., 2006), and the only evidence of expression of DUSP2 in the periosteum was given by another paper from our group (R.D. Fanganiello et al., 2007). DUSP2 has high affinity for members of the MAPK family (MEK/ERK, p38 and JNK) and dephosphorylates its substrates on both tyrosine and threonine (Patterson et al., 2009). P-ERK, another member of the MAPKs and a substrate for DUSP2, could also be regulated by the deregulated amounts of DUSP2 in the Apert cells. Our data show a positive correlation between p-ERK and DUSP2, which does not support this hypothesis. Furthermore, we can assume that DUSP2 is not controlling the p-ERK levels since the inhibition of ERK was followed by lower DUSP2 levels.

In summary, our data have shown that the activation of FGFRs modulates the protein levels of DUSP2 in Fibroblasts from the periosteum of both Apert syndrome patients and controls not carrying the FGFR2 ${ }^{\mathrm{S} 252 \mathrm{~W}}$ mutation. It also has shown that the downstream pathways responsible for this control is different on FGFR2 $2^{5252 \mathrm{~W}}$ fibroblasts when compared to non-mutant ones, the Apert fibroblasts controlled the DUSP2 levels by the PI3-K pathway and the control fibroblasts by the MEK/ERK pathway. It was also demonstrated that DUSP2 concentration is negatively related to the phosphorylation levels of JNK, which corroborates the hypothesis that DUSP2 is acting as a negative regulator of P-JNK in these cells. This new knowledge has important implication in how we understand the pathophysiology of the premature suture closure since it is not yet known how exactly the FGFR2 $2^{5252 \mathrm{~W}}$ mutation causes the suture closure. It also reinforces the importance of in vitro models in genetic diseases etiology research, since our cellular model, despite being minimalist, is obtained directly from the affected tissue from human patients, which, in contrast with animal models, excludes possible differences due to interspecific characteristics (Mestas et al., 2004). 


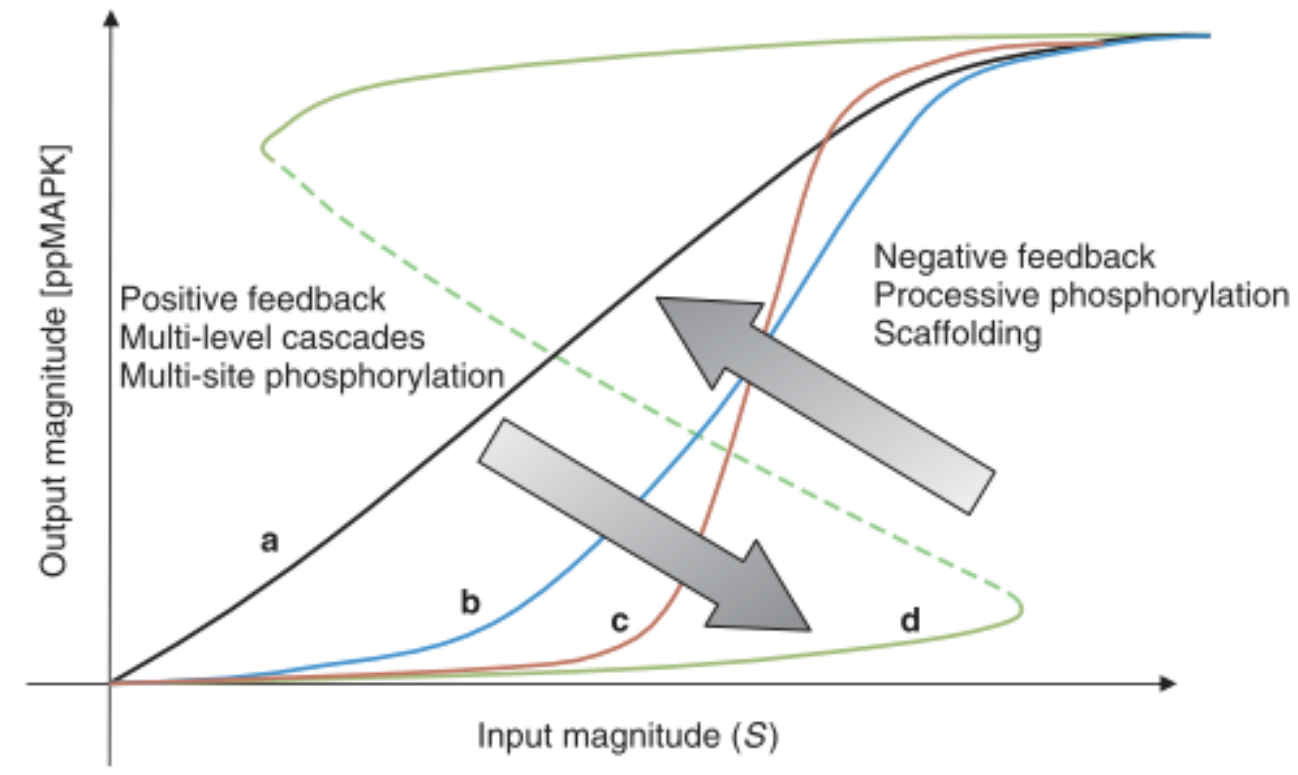

Figure 7: Effects of different charachteristics of the MAPK pathways in the Input/Output ratio. The "d" curve represents a bi-stable state presenting hysteresis. Once the input intensity reaches a threshold, the magnitude of the output increases dramatically, which makes it impossible to predict the output given only the input. Figure from Kholodenko et al, 2009.

\section{General conclusions}

We have demonstrated that FGFR2 activation changes the proteic levels of DUSP2 by different pathways on FGFR2 ${ }^{\mathrm{S} 252 \mathrm{~W}}$ and wild-type fibroblasts, PI3-K and MEK/ERK respectively, and that DUSP2 is involved in the regulation of the phosphorylation levels of JNK in periosteum derived fibroblasts. 


\section{Methods}

Subjects

Coronal suture periosteal fibroblasts from Apert Syndrome patients (FGFR2+/S252W) and from age matched control subjects were obtained as described earlier by us (Fanganiello et al., 2007). Fibroblasts from the same region from Crouzon syndrome patients were obtained following the same protocol. The presence of the $\mathrm{S} 252 \mathrm{~W}$ and the $\mathrm{C} 342 \mathrm{Y}$ mutation was confirmed by direct DNA sequencing and expression of FGFR2c in the primary fibroblasts was examined by Western Blot and RT-PCR.

Cell culture

Primary periosteal fibroblasts derived from periosteal flaps were grown in fibroblast growth medium DMEM High-Glucose, 15\% fetal bovine serum (Invitrogen, Carlsbad, CA, USA) and $2 \mathrm{mmol} / \mathrm{L}$ I-glutamine, penicillin, and streptomycin), in a humidified incubator at $37^{\circ} \mathrm{C}$ and $5 \% \mathrm{CO} 2$. Cells were passaged at near confluence with trypsin-EDTA.

Pharmacological inhibitor treatments

Periosteal fibroblasts were grown until they reached $80 \%$ of confluency. Cells were washed with PBS and then were serum starved for $24 \mathrm{~h}$ in DMEM not supplemented with FBS. After this period control cells were treated with serum starved DMEM High-Glucose and experimental cells were treated with serum starved DMEM High-Glucose, recombinant human FGF2 (PeproTech, Rocky Hill, NJ, USA - diluted in PBS $1 \mathrm{X}$ to a final concentration of $2000 \mathrm{pM}$ ) with or without the addition of $0,1 \mathrm{uM}$ of Wortmannin or 10uM U0126 ethanolate (Sigma-Aldrich) depending on the treatment.

Protein Lysates and Western Blotting

Protein lysates were made after 15 minutes or 2 hours of treatment using the commercial lysis agent Phospho-Safe (EMD4Biosciences) and were quantified according the Bradford Reagent protocol. Equal amounts of protein were loaded into $10 \%$ Bis-Acrylamide gels. The proteins were separated by molecular weight by the discontinuous gel buffer system SDS-PAGE method and transferred to PVDF membranes.

The membranes were than blocked with TBST-BSA 5\% solution, rinsed repeatedly with TBST and incubated with the following antibodies : anti-phospho AKT rabbit, anti phospho ERK rabbit (Cell Signaling), Anti Rabbit-IGG-HRP Mouse (Cell Signaling), Anti DUSP2 mouse (Santa Cruz), Anti mouse-IGGHRP (cell signaling) e anti-B-actin-HRP (ABCAM). The presence of the antibodies were detected by the ECL PLUS reagente protocol. The luminescence was detected using X-Ray films (Kodak). 
The intensity of the bands formed in the X-Ray film was determined using ImageJ (available at http://rsbweb.nih.gov/ij/). The relative protein levels between samples were then determined by first normalizing it by the intensity of the corresponding B-actin band, and secondly by calculating the foldchange between the intensity of the "no treatment" (fixed for every sample as 1 ) and each band of the same membrane and antibody as the corresponding no treatment control.

\section{ELISA}

Equal amounts of protein were incubated in ELISA star Phospho-JNK and JNK (Millipore) plates, and the ELISA protocol was performed according to the manufacturer protocol. The colorimetric assay results were determined using an automated ELISA reader.

Statistical analysis of the protein levels were made by student's t test. The adopted level of significance was 0.05

\section{Quantitative Real Time PCR}

Fibroblasts at $80 \%$ confluency in $25 \mathrm{~cm}^{2}$ culture flasks were either starved for 24 hours in serum-free DMEM-High glucose media or cultured in normal growth media (DMEM-HIGH glucose+15\%FBS). RNA extraction was performed using Nucleospin RNA kit (Macherey-Nagel, Düren, Germany).

RNA quality and concentration were accessed by 1.5 percent agarose gel electrophoresis and Nanodrop ND-1000 (Thermo Scientific, Waltham, Massachusetts, USA) respectively.Complementary DNA (cDNA) was produced from $1 \mu \mathrm{g}$ of total RNA using Superscript II reverse transcription kit (Invitrogen, Carlsbad, CA, USA).

For the fibroblast qRT-PCR, assay was performed using approximately 20 ng of CDNA and SYBR Green PCR master mix in an ABI Prism 7500 system (Applied Biosystems, California, USA). The PCR conditions were: $95^{\circ} \mathrm{C}$ for $15 \mathrm{~s}, 60^{\circ} \mathrm{C}$ for $30 \mathrm{~s}$, and $72^{\circ} \mathrm{C}$ for $30 \mathrm{~s}$ for 40 cycles.

Primers were de-signed with Primer Express software V.2.0 (Applied Biosystems) and the amplification efficiency ( $E$ ) of each primer was calculated according to the equation $E=10(-1 / \mathrm{slope})$. The expression data of the stud-ied transcripts were determined by relative quantification in comparison to four endogenous controls (GAPDH, HMBS, HPRT1 and SDHA). We verified the gene expression stability of endogenous con-trols through geNorm VBA applet designed for Microsoft Excel. This tool calculates the most stable reference genes from a set of tested candidate reference genes in a given sample panel, and calculates the gene expression normalization factor for each target sample based on the geometric mean of a user defined number of housekeeping genes (Vandesompele et al., 2002). The expression data is given by the ratio between each transcript $\Delta \Delta \mathrm{Ct}(\mathrm{E} \Delta \mathrm{CT})$ and normalization factor. Primers used in this study are summarized in Table III.1 
Table III.1 Primer sequences used for quantitative Real-Time PCR

\begin{tabular}{|l|l|l|}
\hline Gene & Forward Primer & Reverse Primer \\
\hline GAPDH & TGCACCACCAACTGCTTAGC & GGCATGGACTGTGGTCATG \\
\hline HMBS & GGCAATGCGGCTGCAA & GGGTACCCACGCGAATCAC \\
\hline HPRT & TGACACTGGCAAAACAATGC & GTCCTTTTCACCCAGCAAGC \\
\hline SDHA & TGGGAACAAGAGGGCATCTG & CCACCACTGCATCAAATTCATG \\
\hline JNK & AGCACAGGTGCAGCAGTGATCAA & ATCTACAGCAGCCCAGAGGCCC \\
\hline
\end{tabular}

Statistical analysis of the expression levels were made by one way ANOVA. The adopted level of significance was 0.05

Data Analysis

The proteic levels of DUSP2, JNK, p-JNK, p-AKT and p-ERK were plotted against each other in scatter plots using GraphPad Prism 5 software.To verify the linear relationship between each proteic levels for the same sample we calculated the linear regression. To verify existence of hysteresis in the mutual regulation of the protein levels, we tested for the possibility of multiple linear regressions, if the double linear pattern had a R2 of at least 0,9 for both lines, the hysteresis hypothesis was accepted and the regulation was considered to happen at 2 distinct rates.

\section{Bibliography}

Alberius, P., Dahlin, C., \& Linde, A. (1992). Role of osteopromotion in experimental bone grafting to the skull: a study in adult rats using a membrane technique. Journal of oral and maxillofacial surgery official journal of the American Association of Oral and Maxillofacial Surgeons, 50(8), 829-834.

Allen, M. R., Hock, J. M., \& Burr, D. B. (2004). Periosteum: biology, regulation, and response to osteoporosis therapies. Bone, 35(5), 1003-12. doi:10.1016/j.bone.2004.07.014

Ang, B. U., Spivak, R. M., Nah, H.-D., \& Kirschner, R. E. (2010). Dura in the pathogenesis of syndromic craniosynostosis: fibroblast growth factor receptor 2 mutations in dural cells promote osteogenic proliferation and differentiation of osteoblasts. The Journal of craniofacial surgery, 21(2), 462-467.

Armelin, H. a. (1973). Pituitary extracts and steroid hormones in the control of 3T3 cell growth. Proceedings of the National Academy of Sciences of the United States of America, 70(9), 2702-6. Retrieved from http://www.pubmedcentral.nih.gov/articlerender.fcgi?artid=427087\&tool=pmcentrez\&rendertyp $\mathrm{e}=\mathrm{abstract}$ 
Artun, J., Osterberg, S. K., \& Kokich, V. G. (1986). Long-term effect of thin interdental alveolar bone on periodontal health after orthodontic treatment. The Journal of periodontology, 57(6), 341-346. Retrieved from http://www.informaworld.com/10.1080/10131750608540424

Aubin, J. E., Gupta, A. K., Bhargava, U., \& Turksen, K. (1996). Expression and regulation of galectin 3 in rat osteoblastic cells. Journal of Cellular Physiology, 169(3), 468-480. Retrieved from http://www.ncbi.nlm.nih.gov/pubmed/8952696

Beenken, A., \& Mohammadi, Moosa. (2009). The FGF family: biology, pathophysiology and therapy. Nature reviews. Drug discovery, 8(3), 235-53. doi:10.1038/nrd2792

Bennett, B. L., Sasaki, D. T., Murray, B. W., O’Leary, E. C., Sakata, S. T., Xu, W., Leisten, J. C., et al. (2001). SP600125, an anthrapyrazolone inhibitor of Jun N-terminal kinase. Proceedings of the National Academy of Sciences of the United States of America, 98(24), 13681-13686. The National Academy of Sciences. Retrieved from

http://www.pubmedcentral.nih.gov/articlerender.fcgi?artid=61101\&tool=pmcentrez\&rendertype $=$ abstract

Bueno, Daniela Franco, Kerkis, I., Costa, A. M., Martins, M. T., Kobayashi, G. S., Zucconi, E., Fanganiello, Roberto Dalto, et al. (2009). New source of muscle-derived stem cells with potential for alveolar bone reconstruction in cleft lip and/or palate patients. Tissue engineering Part A, 15(2), 427-435. Retrieved from http://www.ncbi.nlm.nih.gov/pubmed/18816169

Bulfield, G. (1984). X Chromosome-Linked Muscular Dystrophy (mdx) in the Mouse. Proceedings of the National Academy of Sciences, 81(4), 1189-1192. doi:10.1073/pnas.81.4.1189

Bullaughey, K., Chavarria, C. I., Coop, G., \& Gilad, Y. (2009). Expression quantitative trait loci detected in cell lines are often present in primary tissues. Human Molecular Genetics, 18(22), 4296-4303. Oxford University Press. Retrieved from http://www.pubmedcentral.nih.gov/articlerender.fcgi?artid=2766291\&tool=pmcentrez\&renderty pe $=$ abstract

Bunney, T. D., \& Katan, M. (2011). PLC regulation: emerging pictures for molecular mechanisms. Trends in biochemical sciences, 36(2), 88-96. Elsevier Ltd. doi:10.1016/j.tibs.2010.08.003

Chalhoub, N., \& Baker, S. J. (2009). PTEN and the PI3-kinase pathway in cancer. Annual review of pathology, 4(1), 127. NIH Public Access. doi:10.1146/annurev.pathol.4.110807.092311.PTEN

Chellaiah, A. T., McEwen, D. G., Werner, S., Xu, J., \& Ornitz, D M. (1994). Fibroblast growth factor receptor (FGFR) 3. Alternative splicing in immunoglobulin-like domain III creates a receptor highly specific for acidic FGF/FGF-1. The Journal of Biological Chemistry, 269(15), 11620-11627. Retrieved from http://www.ncbi.nlm.nih.gov/pubmed/7512569 
Chen, L. (2003). A Ser250Trp substitution in mouse fibroblast growth factor receptor 2 (Fgfr2) results in craniosynostosis. Bone, 33(2), 169-178. doi:10.1016/S8756-3282(03)00222-9

Cohen JR, M. M., \& Kreiborg, S. (1992). New indirect method for estimating the birth prevalence of the Apert syndrome. Int J Oral Maxillofac Surg, 21(2), 107-109.

Cohen Jr., M. M., \& MacLean, R. E. (2000). Craniosynostosis. Diagnosis, Evaluation and Management (Second.).

Cohen, M M. (1975). An etiologic and nosologic overview of craniosynostosis syndromes. Birth Defects Original Article Series, 11(2), 137-189. Retrieved from

http://www.ncbi.nlm.nih.gov/entrez/query.fcgi? $\mathrm{cmd}=$ Retrieve $\& \mathrm{db}=\mathrm{PubMed} \& d o p t=C i t a t i o n \& l i s t$ _uids $=179637$

Cohen, M Michael. (1986). Perspectives on craniosynostosis. The Journal of craniofacial surgery, 20 Suppl 1, 646-51. doi:10.1097/SCS.0b013e318193d48d

Colnot, C. (2009). Skeletal cell fate decisions within periosteum and bone marrow during bone regeneration. Journal of bone and mineral research the official journal of the American Society for Bone and Mineral Research, 24(2), 274-282.

Dhillon, K. K., Sidorova, J. M., Albertson, T. M., Anderson, J. B., Ladiges, W. C., Rabinovitch, P. S., Preston, B. D., et al. (2010). Divergent cellular phenotypes of human and mouse cells lacking the Werner syndrome RecQ helicase. DNA Repair, 9(1), 11-22. Elsevier B.V. Retrieved from http://www.ncbi.nlm.nih.gov/pubmed/19896421

Eswarakumar, V. P., Lax, I., \& Schlessinger, J. (2005). Cellular signaling by fibroblast growth factor receptors. Cytokine \& growth factor reviews, 16(2), 139-49. Oxford, UK: Elsevier Science Ltd., c1996-. doi:10.1016/j.cytogfr.2005.01.001

Fakhry, A., Ratisoontorn, C., Vedhachalam, C., Salhab, I., Koyama, E., Leboy, P., Pacifici, M., et al. (2005). Effects of FGF-2/-9 in calvarial bone cell cultures: differentiation stage-dependent mitogenic effect, inverse regulation of BMP-2 and noggin, and enhancement of osteogenic potential. Bone, 36(2), 254-66. doi:10.1016/j.bone.2004.10.003

Fanganiello, R.D., Sertié, A.L., Reis, E. M., Yeh, E., Oliveira, N. A. J., Bueno, D.F., Kerkis, I., et al. (2007). Apert p. Ser252Trp mutation in FGFR2 alters osteogenic potential and gene expression of cranial periosteal cells. Molecular Medicine, 13(7-8), 422. The Feinstein Institute for Medical Research. doi:10.2119/2007

Foster, K. A., Frim, D. M., \& McKinnon, M. (2008). Recurrence of synostosis following surgical repair of craniosynostosis. Plastic and Reconstructive Surgery, 121(3), 70e-76e. Retrieved from http://www.ncbi.nlm.nih.gov/pubmed/18317088

Freshney, R. I. (2005). Culture of animal cells: a manual of basic technique. (J. W. Sons, Ed.)4th ed New York WileyLiss (Vol. 42, p. 642). John Wiley \& Sons. doi:10.1290/BR090501.1 
Furdui, C. M., Lew, E. D., Schlessinger, Joseph, \& Anderson, K. S. (2006). Autophosphorylation of FGFR1 kinase is mediated by a sequential and precisely ordered reaction. Molecular cell, 21(5), 711-7. doi:10.1016/j.molcel.2006.01.022

Ge, C., Xiao, G., Jiang, D., \& Franceschi, R. T. (2007). Critical role of the extracellular signalregulated kinase-MAPK pathway in osteoblast differentiation and skeletal development. The Journal of Cell Biology, 176(5), 709-718. The Rockefeller University Press. Retrieved from http://www.pubmedcentral.nih.gov/articlerender.fcgi?artid=2064027\&tool=pmcentrez\&renderty pe $=$ abstract

Givol, D. (1992). Complexity of FGF receptors: genetic basis for structural diversity and functional specificity. The FASEB journal official publication of the Federation of American Societies for Experimental Biology, 6(15), 3362-3369. Retrieved from http://www.fasebj.org/cgi/reprint/6/15/3362.pdf

Glaser, R. L., Broman, K. W., Schulman, R. L., Eskenazi, B., Wyrobek, A. J., \& Jabs, Ethylin Wang. (2003). The paternal-age effect in Apert syndrome is due, in part, to the increased frequency of mutations in sperm. The American Journal of Human Genetics, 73(4), 939-947. The American Society of Human Genetics. Retrieved from http://www.pubmedcentral.nih.gov/articlerender.fcgi?artid=1180614\&tool=pmcentrez\&renderty pe $=$ abstract

Gospodarowicz, D. (1974). Localisation of a fibroblast growth factor and its effect alone and with hydrocortisone on $3 \mathrm{~T} 3$ cell growth. Nature, 249(453), 123-127. Retrieved from http://www.ncbi.nlm.nih.gov/pubmed/4364816

Gregory, C. A., Gunn, W. G., Peister, A., \& Prockop, D. J. (2004). An Alizarin red-based assay of mineralization by adherent cells in culture: comparison with cetylpyridinium chloride extraction. Analytical biochemistry, 329(1), 77-84. doi:10.1016/j.ab.2004.02.002

Guicheux, J., Lemonnier, J., Ghayor, C., Suzuki, A., Palmer, G., \& Caverzasio, J. (2003). Activation of p38 mitogen-activated protein kinase and c-Jun-NH2-terminal kinase by BMP-2 and their implication in the stimulation of osteoblastic cell differentiation. Journal of bone and mineral research the official journal of the American Society for Bone and Mineral Research, 18(11), 2060-2068. Retrieved from http://www.ncbi.nlm.nih.gov/pubmed/14606520

Haley, P. J. (2003). Species differences in the structure and function of the immune system. Toxicology, 188(1), 49-71. Elsevier. Retrieved from http://linkinghub.elsevier.com/retrieve/pii/S0300483X0300043X

Harries, L. W., Brown, J. E., \& Gloyn, A. L. (2009). Species-Specific Differences in the Expression of the HNF1A, HNF1B and HNF4A Genes. (B. Breant, Ed.)PLoS ONE, 4(11), 7. Public Library of Science.

Holmes, G., Rothschild, G., Roy, U. B., Deng, C.-xia, Mansukhani, A., Basilico, C., \& Basu, U. (2009). Early onset of craniosynostosis in an Apert mouse model reveals critical features of this 
pathology. Developmental biology, 328(2), 273-84. Elsevier Inc. doi:10.1016/j.ydbio.2009.01.026

Hosoi, T. (2010). Genetic aspects of osteoporosis. Journal of Bone and Mineral Metabolism, 28(6), 601-607. Retrieved from http://www.ncbi.nlm.nih.gov/pubmed/20697753

Ibrahimi, O. A., Zhang, F, Eliseenkova, A. V., Itoh, N, Linhardt, R J, \& Mohammadi, M. (2004). Biochemical analysis of pathogenic ligand-dependent FGFR2 mutations suggests distinct pathophysiological mechanisms for craniofacial and limb abnormalities. Hum Mol Genet, 13, 2313-2324. doi:10.1093/hmg/ddh235

Ibrahimi, O., Zhang, Fuming, Hrstka, S. C. L., Mohammadi, Moosa, \& Linhardt, Robert J. (2004). Kinetic model for FGF, FGFR, and proteoglycan signal transduction complex assembly. Biochemistry, 43(16), 4724-30. doi:10.1021/bi0352320

Ito, Y., Sanyal, A., Fitzsimmons, J. S., Mello, M. A., \& O’Driscoll, S. W. (2001).

Histomorphological and proliferative characterization of developing periosteal neochondrocytes in vitro. Journal of Orthopaedic Research, 19(3), 405-413. Retrieved from http://www.ncbi.nlm.nih.gov/pubmed/11398853

Jeffrey, K. L., Brummer, T., Rolph, M. S., Liu, S. M., Callejas, N. A., Grumont, R. J., Gillieron, C., et al. (2006). Positive regulation of immune cell function and inflammatory responses by phosphatase PAC-1. Nature immunology, 7(3), 274-83. doi:10.1038/ni1310

Jehee, F. S., Krepischi-Santos, a C. V., Rocha, K. M., Cavalcanti, D. P., Kim, C. a, Bertola, D. R., Alonso, L. G., et al. (2008). High frequency of submicroscopic chromosomal imbalances in patients with syndromic craniosynostosis detected by a combined approach of microsatellite segregation analysis, multiplex ligation-dependent probe amplification and array-based comparative genome. Journal of medical genetics, 45(7), 447-50. doi:10.1136/jmg.2007.057042

Johnson, David. (2003). A comprehensive screen of genes implicated in craniosynostosis. Annals of the Royal College of Surgeons of England, 85(6), 371-377. The Royal College of Surgeons of England. Retrieved from http://www.ingentaconnect.com/content/rcse/arcs/2003/00000085/00000006/art00001

Joiakim, A., Mathieu, P. A., Palermo, C., Gasiewicz, T. A., \& Reiners, J. J. (2003). The Jun Nterminal kinase inhibitor SP600125 is a ligand and antagonist of the aryl hydrocarbon receptor. Drug metabolism and disposition the biological fate of chemicals, 31(11), 1279-1282. Retrieved from

http://www.ncbi.nlm.nih.gov/entrez/query.fcgi?cmd=Retrieve\&db=PubMed\&dopt=Citation\&list _uids=14570754

Kholodenko, B. N., \& Birtwistle, M. R. (2009). Four-dimensional dynamics of MAPK information-processing systems. Cell. doi:10.1002/wsbm.016 
Kimonis, V., Gold, J.-anne J., Hoffman, T. T. L., Panchal, J., \& Boyadjiev, S. A. (2007).

Genetics of craniosynostosis. Seminars in Pediatric Neurology, 1-3.

doi:10.1016/j.spen.2007.08.008

Klint, P., \& Claesson-Welsh, L. (1999). Signal transduction by fibroblast growth factor receptors. Front Biosci, 4(22), D165-77. Retrieved from

http://www.bioscience.org/1999/v4/d//klint/fulltext.htm

Krishna, M., \& Narang, H. (2008). Review The complexity of mitogen-activated protein kinases ( MAPKs ) made simple. Cellular and Molecular Life Sciences, 65, 3525 - 3544.

doi:10.1007/s00018-008-8170-7

Lajeunie, E., Cameron, R., El Ghouzzi, V., De Parseval, N., Journeau, P., Gonzales, M., Delezoide, A. L., et al. (1999). Clinical variability in patients with Apert's syndrome. Journal Of Neurosurgery, 90(3), 443-447. Retrieved from http://www.ncbi.nlm.nih.gov/pubmed/10067911

Langille, R. M. (1994). Chondrogenic differentiation in cultures of embryonic rat mesenchyme. Microscopy Research and Technique, 28(6), 455-469.

Lemmon, M. A., \& Schlessinger, Joseph. (2010). Cell signaling by receptor tyrosine kinases. Cell, 141(7), 1117-34. doi:10.1016/j.cell.2010.06.011

Levine, J. P., Bradley, J. P., Roth, D. A., McCarthy, J. G., \& Longaker, M T. (1998). Studies in cranial suture biology: regional dura mater determines overlying suture biology. Plastic and Reconstructive Surgery, 101(6), 1441-1447.

Li, Chaoying, Scott, D. a, Hatch, E., Tian, X., \& Mansour, S. L. (2007). Dusp6 (Mkp3) is a negative feedback regulator of FGF-stimulated ERK signaling during mouse development. Development (Cambridge, England), 134(1), 167-76. doi:10.1242/dev.02701

Lilli, C., Bellucci, C., Baroni, T., Aisa, C., Carinci, P., Scapoli, L., Carinci, F., et al. (2007). FGF2 effects in periosteal fibroblasts bearing the FGFR2 receptor Pro253 Arg mutation. Cytokine, 38(1), 22-31.

Liu, H., Liu, Y., Viggeswarapu, M., Zheng, Z., Titus, L., \& Boden, S. D. (2010). Activation of cJun NH(2)-terminal kinase 1 increases cellular responsiveness to BMP-2 and decreases binding of inhibitory Smad6 to the type I BMP receptor. Journal of bone and mineral research : the official journal of the American Society for Bone and Mineral Research, 404-417. doi:10.1002/jbmr.296

Lomri, a, Lemonnier, J., Hott, M., de Parseval, N., Lajeunie, E., Munnich, a, Renier, D., et al. (1998). Increased calvaria cell differentiation and bone matrix formation induced by fibroblast growth factor receptor 2 mutations in Apert syndrome. The Journal of clinical investigation, 101(6), 1310-7. Retrieved from http://www.pubmedcentral.nih.gov/articlerender.fcgi?artid=508685\&tool=pmcentrez\&rendertyp $\mathrm{e}=\mathrm{abstract}$ 
Lopez-Bergami, P., Huang, C., Goydos, J. S., Yip, D., Bar-Eli, M., Herlyn, M., Smalley, K. S. M., et al. (2007). Rewired ERK-JNK signaling pathways in melanoma. Cancer Cell, 11(5), 447460. Retrieved from

http://www.pubmedcentral.nih.gov/articlerender.fcgi?artid=1978100\&tool=pmcentrez\&renderty pe $=$ abstract

Mansukhani, A., Bellosta, P., Sahni, M., \& Basilico, C. (2000). Signaling by Fibroblast Growth Factors (Fgf) and Fibroblast Growth Factor Receptor 2 (Fgfr2)-Activating Mutations Blocks Mineralization and Induces Apoptosis in Osteoblasts. The Journal of Cell Biology, 149(6), $1297-$ 1308. The Rockefeller University Press. Retrieved from

http://www.pubmedcentral.nih.gov/articlerender.fcgi?artid=2175120\&tool=pmcentrez\&renderty pe $=$ abstract

Marie, P. J. (2003). Fibroblast growth factor signaling controlling osteoblast differentiation. Gene, 316, 23-32. Retrieved from http://linkinghub.elsevier.com/retrieve/pii/S0378111903007480

Matsuguchi, T., Chiba, N., Bandow, K., Kakimoto, K., Masuda, A., \& Ohnishi, T. (2009). JNK activity is essential for Atf4 expression and late-stage osteoblast differentiation. Journal of bone and mineral research the official journal of the American Society for Bone and Mineral Research, 24(3), 398-410. Retrieved from http://www.ncbi.nlm.nih.gov/entrez/query.fcgi?cmd=Retrieve \&db=PubMed\&dopt=Citation\&list _uids $=19016586$

McHugh, T., Wyers, M., \& King, E. (2007). MRI characterization of the glenohumeral joint in Apert syndrome. Pediatric Radiology.

De Mendonça Costa, A., Bueno, Daniela F, Martins, M. T., Kerkis, I., Kerkis, A., Fanganiello, Roberto D, Cerruti, H., et al. (2008). Reconstruction of large cranial defects in nonimmunosuppressed experimental design with human dental pulp stem cells. The Journal of craniofacial surgery, 19(1), 204-210. Retrieved from http://www.ncbi.nlm.nih.gov/pubmed/18216690

Mestas, J., \& Hughes, C. C. W. (2004). Of mice and not men: differences between mouse and human immunology. Journal of immunology (Baltimore, Md. : 1950), 172(5), 2731-8. Retrieved from http://www.ncbi.nlm.nih.gov/pubmed/14978070

Miki, T., Bottaro, D. P., Fleming, T. P., Smith, C. L., Burgess, W. H., Chan, A. M., \& Aaronson, S. A. (1992). Determination of ligand-binding specificity by alternative splicing: two distinct growth factor receptors encoded by a single gene. Proceedings of the National Academy of Sciences of the United States of America, 89(1), 246-250. Retrieved from http://www.pubmedcentral.nih.gov/articlerender.fcgi?artid=48213\&tool=pmcentrez\&rendertype $=\mathrm{abstract}$

Miraoui, H., Oudina, K., Petite, H., Tanimoto, Y., Moriyama, K., \& Marie, P. J. (2009).

Fibroblast growth factor receptor 2 promotes osteogenic differentiation in mesenchymal cells via 
ERK1/2 and protein kinase C signaling. The Journal of Biological Chemistry, 284(8), 4897-904. doi:10.1074/jbc.M805432200

Miura, T., Perlyn, C. a, Kinboshi, M., Ogihara, N., Kobayashi-Miura, M., Morriss-Kay, Gillian M, \& Shiota, K. (2009). Mechanism of skull suture maintenance and interdigitation. Journal of anatomy, 215(6), 642-55. doi:10.1111/j.1469-7580.2009.01148.x

Moloney, D. M., Slaney, S. F., Oldridge, M., Wall, S A, Sahlin, P., Stenman, G., \& Wilkie, A. O. (1996). Exclusive paternal origin of new mutations in Apert syndrome. Nature Genetics, 13(1), 48-53.

Naski, M. C., \& Ornitz, D M. (1998). FGF signaling in skeletal development. Frontiers in Bioscience, 3(4), 781-794. Informa UK Ltd UK. doi:10.3109/15513819809168795

Ninomiya, J. T., Tracy, R. P., Calore, J. D., Gendreau, M. A., Kelm, R. J., \& Mann, K. G. (1990). Heterogeneity of human bone. Journal of bone and mineral research the official journal of the American Society for Bone and Mineral Research, 5(9), 933-938.

Oldridge, M., Zackai, E. H., McDonald-McGinn, D. M., Iseki, S., Morriss-Kay, G M, Twigg, S. R., Johnson, D, et al. (1999). De novo alu-element insertions in FGFR2 identify a distinct pathological basis for Apert syndrome. The American Journal of Human Genetics, 64(2), 446461. Retrieved from

http://www.pubmedcentral.nih.gov/articlerender.fcgi?artid=1377754\&tool=pmcentrez\&renderty pe $=$ abstract

Opperman, L A. (2000). Cranial sutures as intramembranous bone growth sites. Developmental dynamics an official publication of the American Association of Anatomists, 219(4), 472-485. Retrieved from http://www.ncbi.nlm.nih.gov/pubmed/11084647

Opperman, Lynne A, Sweeney, T. M., Redmon, J., Persing, J. A., \& Ogle, R. C. (1993). Tissue interactions with underlying dura mater inhibit osseous obliteration of developing cranial sutures. Developmental dynamics an official publication of the American Association of Anatomists, 198(4), 312-22. doi:10.1002/aja.1001980408

Ornitz, D M. (2000). FGFs, heparan sulfate and FGFRs: complex interactions essential for development. BioEssays news and reviews in molecular cellular and developmental biology, 22(2), 108-112. Am Soc Microbiol. Retrieved from

http://www.ncbi.nlm.nih.gov/pubmed/10655030

Ornitz, David M, \& Itoh, Nobuyuki. (2001). Fibroblast growth factors. Genome Biology, 2(3), reviews3005.1-reviews3005.12. BioMed Central. Retrieved from

http://www.ncbi.nlm.nih.gov/pubmed/10687947

Orr-Urtreger, A., Bedford, M. T., Burakova, T., Arman, E., Zimmer, Y., Yayon, A., Givol, D., et al. (1993). Developmental localization of the splicing alternatives of fibroblast growth factor 
receptor-2 (FGFR2). Developmental Biology, 158(2), 475-486. Retrieved from http://www.ncbi.nlm.nih.gov/pubmed/8393815

Ozerdem, O. R., Anlatici, R., Bahar, T., Kayaselçuk, F., Barutçu, O., Tuncer, I., \& Sen, O. (2003). Roles of periosteum, dura, and adjacent bone on healing of cranial osteonecrosis. The Journal of craniofacial surgery, 14(3), 371-379; discussion 380-382.

Park, W. J., Theda, C., Maestri, N. E., Meyers, G. A., Fryburg, J. S., Dufresne, C., Cohen, M M, et al. (1995). Analysis of phenotypic features and FGFR2 mutations in Apert syndrome. The American Journal of Human Genetics, 57(2), 321-328. Retrieved from http://www.pubmedcentral.nih.gov/articlerender.fcgi?artid=1801532\&tool=pmcentrez\&renderty pe $=$ abstract

Passos-Bueno, M R, Richieri-Costa, A., Sertié, A L, \& Kneppers, A. (1998). Presence of the Apert canonical S252W FGFR2 mutation in a patient without severe syndactyly. Journal of Medical Genetics, 35(8), 677-679. Retrieved from

http://www.pubmedcentral.nih.gov/articlerender.fcgi?artid=1051397\&tool=pmcentrez\&renderty pe $=$ abstract

Passos-Bueno, M R, Sertié, A L, Zatz, M., \& Richieri-Costa, A. (1997). Pfeiffer mutation in an Apert patient: how wide is the spectrum of variability due to mutations in the FGFR2 gene? American Journal of Medical Genetics. Wiley Online Library. Retrieved from http://onlinelibrary.wiley.com/doi/10.1002/(SICI)1096-8628(19970808)71:2<243::AIDAJMG27>3.0.CO;2-D/abstract

Passos-Bueno, M., Sertie, A., Jehee, F., Fanganiello, R., \& Yeh, E. (2008). Genetics of craniosynostosis: genes, syndromes, mutations and genotype-phenotype correlations. Craniofacial sutures: development, disease and treatment, 12, 107-143. Karger. Retrieved from http://books.google.com/books?hl=en\&amp;lr=\&amp;id=Z59zHPG711gC\&amp;oi=fnd\&amp;pg =PA107\&amp; $\mathrm{dq}=$ Genetics+of+Craniosynostosis:+Genes, + Syndromes, + Mutations+and+Genot ype-Phenotype+Correlations\&amp;ots $=$ XqFsP_CjX\&amp;sig=zWLyP6XNE7FxjsjSU2Q2c0PwDB4

Patterson, K. I., Brummer, T., Brien, P. M. O., Daly, R. J., \& O’BRIEN, P. M. (2009). Dualspecificity phosphatases : critical regulators with diverse cellular targets. Biochemical journal, 418(2009), 475-489. Portland Press. doi:10.1042/BJ20082234

Posnick, J. C., Armstrong, D., \& Bite, U. (1995). Crouzon and Apert syndromes: intracranial volume measurements before and after cranio-orbital reshaping in childhood. Plastic and Reconstructive Surgery, 96(3), 539-548.

Renier, D., Arnaud, E., Cinalli, G., Marchac, D., Brunet, L., Sebag, G., Sainte-Rose, C., et al. (1996). Mental prognosis of Apert syndrome. Archives of Pediatrics, 3(8), 752-760. 
Roth, D. A., Bradley, J. P., Levine, J. P., McMullen, H. F., McCarthy, J. G., \& Longaker, M T. (1996). Studies in cranial suture biology: part II. Role of the dura in cranial suture fusion. Plastic and Reconstructive Surgery, 97(4), 693-699.

Scadden, D. T. (2006). The stem-cell niche as an entity of action. Nature, 441(7097), 1075-9. doi:10.1038/nature04957

Schlessinger, J, Plotnikov, A. N., Ibrahimi, O. A., Eliseenkova, A. V., Yeh, B. K., Yayon, A., Linhardt, R J, et al. (2000). Crystal structure of a ternary FGF-FGFR-heparin complex reveals a dual role for heparin in FGFR binding and dimerization. Molecular Cell, 6(3), 743-750.

Retrieved from http://www.ncbi.nlm.nih.gov/pubmed/11030354

Shaul, Y. D., \& Seger, R. (2007). The MEK/ERK cascade: from signaling specificity to diverse functions. Biochimica et biophysica acta, 1773(8), 1213-26. doi:10.1016/j.bbamcr.2006.10.005

Shukla, V., Coumoul, X., Wang, R.-hong, Kim, H.-seok, \& Deng, C.-xia. (2007). RNA interference and inhibition of MEK-ERK signaling prevent abnormal skeletal phenotypes in a mouse model of craniosynostosis. Nature Genetics, 39(9), 1145-1150. doi:10.1038/ng2096

Slater, B. J., Lenton, K. A., Kwan, M. D., Gupta, D. M., Wan, D. C., \& Longaker, Michael T. (2008). Cranial sutures: a brief review. Plastic and Reconstructive Surgery, 121(4), 170e-8e. Retrieved from http://www.ncbi.nlm.nih.gov/pubmed/18349596

Squier, C. A., Ghoneim, S., \& Kremenak, C. R. (1990). Ultrastructure of the periosteum from membrane bone. Journal of Anatomy, 171, 233-239. Retrieved from

http://www.ncbi.nlm.nih.gov/pubmed/2081707

Su, N., Sun, Q., Li, Can, Lu, X., Qi, H., Chen, S., Yang, J., et al. (2010). Gain-of-function mutation in FGFR3 in mice leads to decreased bone mass by affecting both osteoblastogenesis and osteoclastogenesis. Human Molecular Genetics, 19(7), 1199-1210. Oxford University Press. Retrieved from http://www.ncbi.nlm.nih.gov/pubmed/20053668

Tolarova, M. M., Harris, J. A., Ordway, D. E., \& Vargervik, K. (1997). Birth prevalence, mutation rate, sex ratio, parents' age, and ethnicity in Apert syndrome. American Journal of Medical Genetics, 72(4), 394-398.

Trueb, B., Zhuang, L., Taeschler, S., \& Wiedemann, M. (2003). Characterization of FGFRL1, a novel fibroblast growth factor (FGF) receptor preferentially expressed in skeletal tissues. The Journal of Biological Chemistry, 278(36), 33857-33865. Retrieved from http://www.ncbi.nlm.nih.gov/pubmed/12813049

Wang, Y., Sun, M., Uhlhorn, V. L., Zhou, X., Peter, I., Martinez-Abadias, N., Hill, C. A., et al. (2010). Activation of p38 MAPK pathway in the skull abnormalities of Apert syndrome Fgfr2+P253R mice. BMC Developmental Biology, 10, 22. BioMed Central. Retrieved from http://www.pubmedcentral.nih.gov/articlerender.fcgi? artid=2838826\&tool=pmcentrez\&renderty pe $=$ abstract 
Wang, Y., Xiao, R., Yang, F., Karim, B. O., Iacovelli, A. J., Cai, J., Lerner, C. P., et al. (2002). Abnormalities in cartilage and bone development in the Apert syndrome FGFR2 + / S252W mouse. Development. doi:10.1242/dev.01914

Wilkie, A. O. (1997). Craniosynostosis: genes and mechanisms. Human Molecular Genetics, 6(10), 1647-1656. Retrieved from http://www.ncbi.nlm.nih.gov/pubmed/9300656

Wilkie, A. O. M., Byren, J. C., Hurst, J. a, Jayamohan, J., Johnson, David, Knight, S. J. L., Lester, T., et al. (2010). Prevalence and complications of single-gene and chromosomal disorders in craniosynostosis. Pediatrics, 126(2), e391-400. doi:10.1542/peds.2009-3491

Wilkie, A. O., \& Morriss-Kay, G M. (2001). Genetics of craniofacial development and malformation. Nat Rev Genet, 2, 458-468. doi:10.1038/35076601

Wilkie, A. O., Slaney, S. F., Oldridge, M., Poole, M. D., Ashworth, G. J., Hockley, A. D., Hayward, R. D., et al. (1995). Apert syndrome results from localized mutations of FGFR2 and is allelic with Crouzon syndrome. Nature Genetics, 9(2), 165-172.

Yang, F., Wang, Y., Zhang, Z., Hsu, B., Jabs, Ethylin Wang, \& Elisseeff, J. H. (2008). The study of abnormal bone development in the Apert syndrome Fgfr2+/S252W mouse using a 3D hydrogel culture model. Bone, 43(1), 55-63. Retrieved from http://www.ncbi.nlm.nih.gov/pubmed/17707711

Yeh, E. (2011). Estudo da contribuição molecular e celular do periósteo na craniossinostose da síndrome de Apert. Universidade de São Paulo.

Yeh, E., Atique, R., Ishiy, F., Fanganiello, R., Alonso, N., Matsushita, H., \& Passos-bueno, M. R. (2011). FGFR2 Mutation Confers a Less Drastic Gain of Function in Mesenchymal Stem Cells Than in Fibroblasts. Stem Cell Reviews and Reports. doi:10.1007/s12015-011-9327-6

Zollikofer, C. P. E., \& Ponce De León, M. S. (2010). The evolution of hominin ontogenies. Seminars in cell developmental biology, 21(4), 441-452. Retrieved from http://www.ncbi.nlm.nih.gov/pubmed/19900572 


\section{Capítulo IV}

\section{Discussão geral e conclusões}

Os osteoblastos presentes na sutura afetada pela síndrome de Apert são considerados as principais células atuantes na patofisiologia da S. de Apert, no entanto as conclusões contraditórias encontradas nos diversos modelos de estudo apontam para a participação de outros tecidos e tipos celulares no fechamento persistente da sutura coronal, o que foi uma importante motivação para o desenvolvimento do presente estudo.

A mutação FGFR2 ${ }^{5252 W}$ tem um efeito positivo sobre a proliferação e migração de fibroblastos, e um efeito negativo sobre a proliferação de MSCs e nenhum sobre a migração MSCs. Apesar de não podermos distinguir estes dois tipos de células com base no imunofenótipo ou na morfologia celular, o estudo comparativo do fenótipo celular de fibroblastos e MSCs portadores da mutação S252W em FGFR2 nos mostrou o quão diferente são e nos permitiu delinear um modelo de como o periósteo influencia na fusão das suturas. Ambos os tipos celulares passam a apresentar maior diferenciação osteogênica e fibroblastos S252W têm influência positiva sobre a diferenciação MSCs. A inibição da fosforilação da JNK por SP600125 anula o efeito da mutação no processo de diferenciação osteogênica atípica de fibroblastos. Isso apresentou a possibilidade da influência de pJNK no aumento da diferenciação osteogênica dos fibroblastos do periósteo. Esses dados indicam que os fibroblastos do periósteo craniano podem estar envolvidos no processo de fechamento de sutura, principalmente como célula sinalizadora desse processo. Como o aumento do potencial osteogênico dos fibroblastos S252W foi revertido pela inibição de p-JNK o maior estudo do envolvimento dessa molécula no processo de fechamento da sutura é necessário. Uma molécula que já foi relacionada à diferenciação osteogênica e têm seu efeito modulado por p-JNK é BMP-2 (H. Liu et al., 2010). Além disso o tratamento 
com anticorpos anti-BMP2 reverteu o aumento que fibroblastos S252W tinham sobre MSCs em condições de co-cultura. Isso nos leva a propor que BMP-2 é uma molécula importante no processo de fechamento da sutura nesses pacientes. Mais experimentos são necessários para verificar se existe aumento da expressão de BMP-2 em fibroblastos S252W.

Embora não tenhamos conseguido demonstrar diferenças estatisticamente significativas nos níveis de fosforilação de JNK de fibroblastos FGFR2 ${ }^{\text {S252W }}$, encontramos indícios de que a expressão de JNK está alterada nessas células, estando mais expresso em controles quando a cultura não é carenciada e em FGFR2 ${ }^{\text {S252W }}$ quando carenciada, mostrando não só níveis alterados de expressão de JNK devidos à mutação, mas também diferença na regulação da resposta a estímulos. A mutação FGFR2 ${ }^{\text {S252W }}$ também $^{2}$ altera uma via de transdução de sinal downstream a FGFR2, que é responsável pela regulação dos níveis proteicos de DUSP2, uma fosfatase de JNK: em fibroblastos controle encontramos indícios de que a regulação está ocorrendo por intermédio da via MEK/ERK, enquanto nos fibroblastos FGFR2 ${ }^{\text {S252W }}$ a regulação ocorreu pela via PI3-K. Também observamos a relação negativa entre DUSP2 e p-JNK em ambos os casos, indício que DUSP2 está atuando como fosfatase de JNK nessas células. Esses dados preliminares mostram que a mutação S252W não altera só quantitativamente as ativações das vias, mas também qualitativamente. Esses achados precisam ainda ser corroborados por um espaço amostral maior, mas a complexidade das interações entre as vias estudadas aqui já demonstra que as abordagens clássicas para o estudo dessas vias não serão suficientes para entender a amplitude das alterações causadas pela mutação. Novas abordagens devem ser tomadas para aumentar a resolução temporal e de outras variáveis desses experimentos para obtermos um modelo mais claro de como isso ocorre. Outro ponto em aberto é se essas alterações também são válidas para a síndrome de Crouzon. A síndrome de Crouzon, por ser causada por mutações no mesmo gene da síndrome de Apert e por resultar em alguns sinais semelhantes (fusão prematura das suturas coronais) deve compartilhar algumas características moleculares em comum com a S. de Apert. 
Por fim, esse trabalho demonstrou alguns processos inéditos na literatura. Os fibroblastos, normalmente considerados células meramente estruturais, ainda não tinham sido apontados como potenciais sinalizadores do processo de ossificação. A via JNK, embora já tivesse sido relacionada com o processo de formação óssea, ainda não havia sido relacionada com o processo de fechamento precoce das suturas cranianas. A modulação dos níveis proteicos de DUSP2 por FGFR2 e seu papel como fosfatase de JNK em fibroblastos também não haviam sidos demonstrados, bem como o papel da via PI3-K no processo de patogênese da síndrome de Apert. Por fim esse trabalho demonstrou a possível participação de fibroblastos e MSCs no fechamento precoce da sutura coronal na S. de Apert, bem como a importância das vias PI3-K e JNK nesse processo. 


\section{Capítulo V}

\section{Resumo}

Mutações do tipo ganho de função em FGFR2 causam a síndrome de Apert, uma doença rara caracterizada por craniossinostose e defeitos ósseos nos membros devidos a anormalidades na diferenciação e remodelamento ósseos. Apesar do periósteo ser uma importante fonte de células durante o remodelamento ósseo, seu papel nas craniossinostoses ainda é pouco conhecido. A S. de Apert é causada por mutações (p.S252W ou p.P253R) que levam a perda de especificidade de FGFR2 por seus ligantes e causam a ativação exacerbada do mesmo. Sabe-se que FGFR2 ativa vias de sinalização intracelulares como MEK/ERK, PI3-K e PLC. Nossa hipótese é que as células tronco mesenquimais (MSCs) e fibroblastos de pacientes com S. de Apert tem fenótipos celulares e vias de sinalização alterados que contribuem para o fechamento recorrente das suturas coronais. MSCs e fibroblastos foram obtidos do periósteo de pacientes portadores da S. de Apert (S252W) e indivíduos controles (WT). Nós analisamos a proliferação, migração e diferenciação osteogênica dessas células. A mutação S252W teve efeitos opostos em tipos celulares diferentes: MSCs S252W proliferaram menos que as S252W controle, enquanto fibroblastos S252W proliferaram mais que fibroblastos controle, além de terem aumento da migração. A presença da mutação S252W aumentou a diferenciação osteogênica in vitro e in vivo em ambos os tipos celulares estudados. Esse aumento de diferenciação osteogênica foi revertido pela inibição de JNK. Nós demonstramos que fibroblastos S252W podem induzir a diferenciação osteogênica em MSCs de periósteo, porém não em MSCs de outras fontes.

Trabalhos anteriores mostraram que o gene da fosfatase DUSP2 está mais expresso em fibroblastos do periósteo de pacientes portadores da S. de Apert do que em controles. DUSP2 é capaz de desfosforilar membros das MAPKs, dentre estes p-JNK. Nesse trabalho mostramos que a ativação de 
FGFR2 regula os níveis proteicos de DUSP2 tanto em pacientes quanto em controles, porém por vias diferentes em cada caso, e que DUSP2 está regulando negativamente a fosforilação de JNK.Nós propomos que células do periósteo tem um papel mais importante no fechamento precoce das suturas cranianas do que se imaginava anteriormente e que moléculas da via JNK são fortes candidatas para o tratamento de pacientes da S. de Apert. 


\section{Capítulo VI}

\section{Abstract}

Apert Syndrome is cause by gain of Function mutations in FGFR2, a rare condition characterized by craniosynostosis and bone limb defects due to abnormalities in osteogenic differentiation and cone remodeling. Even though the periosteum acts as an important cell source during bone remodeling, its role in craniosynostosis is yet unknown. Apert syndrome is caused by one of two mutations (p.S252W or p.P253R) leading to loss of specificity of FGFR2 by its ligands leading to increased activation of the receptor. It is known that FGFR2 activates the MEK/ERK, PI3-K and PLC signaling pathways. Our hypothesis is that Apert syndrome patients" Mesenchimal Stem Cells (MSCs) and fibroblasts have altered cellular phenotye and signaling pathways which may contribute to the premature closure of the coronal sutures. MSCs and fibroblasts were obtained from the periosteum of Apert syndrome patients bearing the p.S252W mutation and from wild-type (WT) individuals. The p.S252W mutation had opposite effects on different cell types: MSCs p.S252W proliferated less than WT, while p.S252W fibroblasts showed increased proliferation and migration when compared to WT fibroblasts. The presence of the p.S252W mutation increased the osteogenical differentiation in vitro and in vivo in both cell types. We also demonstrated that p.S252W fibroblasts can increase the osteogenic differentiation of MSCs from the periosteum, but not from other sources.

Previous works have shown that the DUSP2 gene had increased expression in periosteum derived fibroblasts of Apert syndrome patients then in WT. DUSP2 is a phosphatase capable of dephosphorylate members of the MAPK family, including p-JNK. In this work we have shown that FGFR2 activation regulates the proteic levels of DUSP2 in both patients and control derived fibroblasts, however this control is exercised by different pathways in each case. We also demonstrated that DUSP2 
is negatively controlling the phosphorylation of JNK. We propose that cells from the periosteum have a more significant role in the premature closure of the cranial sutures than previously thought and that molecules of the JNK pathway are strong candidates for the treatment of Apert syndrome. 


\section{Capítulo VII}

\section{Bibliografia}

Alberius, P., Dahlin, C., \& Linde, A. (1992). Role of osteopromotion in experimental bone grafting to the skull: a study in adult rats using a membrane technique. Journal of oral and maxillofacial surgery official journal of the American Association of Oral and Maxillofacial Surgeons, 50(8), 829-834.

Allen, M. R., Hock, J. M., \& Burr, D. B. (2004). Periosteum: biology, regulation, and response to osteoporosis therapies. Bone, 35(5), 1003-12. doi:10.1016/j.bone.2004.07.014

Ang, B. U., Spivak, R. M., Nah, H.-D., \& Kirschner, R. E. (2010). Dura in the pathogenesis of syndromic craniosynostosis: fibroblast growth factor receptor 2 mutations in dural cells promote osteogenic proliferation and differentiation of osteoblasts. The Journal of craniofacial surgery, 21(2), 462-467.

Armelin, H. a. (1973). Pituitary extracts and steroid hormones in the control of 3T3 cell growth. Proceedings of the National Academy of Sciences of the United States of America, 70(9), 2702-6. Retrieved from http://www.pubmedcentral.nih.gov/articlerender.fcgi?artid=427087\&tool=pmcentrez\&rendertyp $\mathrm{e}=\mathrm{abstract}$

Artun, J., Osterberg, S. K., \& Kokich, V. G. (1986). Long-term effect of thin interdental alveolar bone on periodontal health after orthodontic treatment. The Journal of periodontology, 57(6), 341-346. Retrieved from http://www.informaworld.com/10.1080/10131750608540424

Aubin, J. E., Gupta, A. K., Bhargava, U., \& Turksen, K. (1996). Expression and regulation of galectin 3 in rat osteoblastic cells. Journal of Cellular Physiology, 169(3), 468-480. Retrieved from http://www.ncbi.nlm.nih.gov/pubmed/8952696

Beenken, A., \& Mohammadi, Moosa. (2009). The FGF family: biology, pathophysiology and therapy. Nature reviews. Drug discovery, 8(3), 235-53. doi:10.1038/nrd2792

Bennett, B. L., Sasaki, D. T., Murray, B. W., O’Leary, E. C., Sakata, S. T., Xu, W., Leisten, J. C., et al. (2001). SP600125, an anthrapyrazolone inhibitor of Jun N-terminal kinase. Proceedings of the National Academy of Sciences of the United States of America, 98(24), 13681-13686. The National Academy of Sciences. Retrieved from http://www.pubmedcentral.nih.gov/articlerender.fcgi?artid=61101\&tool=pmcentrez\&rendertype $=$ abstract 
Bueno, Daniela Franco, Kerkis, I., Costa, A. M., Martins, M. T., Kobayashi, G. S., Zucconi, E., Fanganiello, Roberto Dalto, et al. (2009). New source of muscle-derived stem cells with potential for alveolar bone reconstruction in cleft lip and/or palate patients. Tissue engineering Part A, 15(2), 427-435. Retrieved from http://www.ncbi.nlm.nih.gov/pubmed/18816169

Bulfield, G. (1984). X Chromosome-Linked Muscular Dystrophy (mdx) in the Mouse. Proceedings of the National Academy of Sciences, 81(4), 1189-1192. doi:10.1073/pnas.81.4.1189

Bullaughey, K., Chavarria, C. I., Coop, G., \& Gilad, Y. (2009). Expression quantitative trait loci detected in cell lines are often present in primary tissues. Human Molecular Genetics, 18(22), 4296-4303. Oxford University Press. Retrieved from http://www.pubmedcentral.nih.gov/articlerender.fcgi?artid=2766291\&tool=pmcentrez\&renderty pe $=$ abstract

Bunney, T. D., \& Katan, M. (2011). PLC regulation: emerging pictures for molecular mechanisms. Trends in biochemical sciences, 36(2), 88-96. Elsevier Ltd. doi:10.1016/j.tibs.2010.08.003

Chalhoub, N., \& Baker, S. J. (2009). PTEN and the PI3-kinase pathway in cancer. Annual review of pathology, 4(1), 127. NIH Public Access. doi:10.1146/annurev.pathol.4.110807.092311.PTEN

Chellaiah, A. T., McEwen, D. G., Werner, S., Xu, J., \& Ornitz, D M. (1994). Fibroblast growth factor receptor (FGFR) 3. Alternative splicing in immunoglobulin-like domain III creates a receptor highly specific for acidic FGF/FGF-1. The Journal of Biological Chemistry, 269(15), 11620-11627. Retrieved from http://www.ncbi.nlm.nih.gov/pubmed/7512569

Chen, L. (2003). A Ser250Trp substitution in mouse fibroblast growth factor receptor 2 (Fgfr2) results in craniosynostosis. Bone, 33(2), 169-178. doi:10.1016/S8756-3282(03)00222-9

Cohen JR, M. M., \& Kreiborg, S. (1992). New indirect method for estimating the birth prevalence of the Apert syndrome. Int J Oral Maxillofac Surg, 21(2), 107-109.

Cohen Jr., M. M., \& MacLean, R. E. (2000). Craniosynostosis. Diagnosis, Evaluation and Management (Second.).

Cohen, M M. (1975). An etiologic and nosologic overview of craniosynostosis syndromes. Birth Defects Original Article Series, 11(2), 137-189. Retrieved from

http://www.ncbi.nlm.nih.gov/entrez/query.fcgi?cmd=Retrieve \&db=PubMed\&dopt=Citation\&list _uids $=179637$

Cohen, M Michael. (1986). Perspectives on craniosynostosis. The Journal of craniofacial surgery, 20 Suppl 1, 646-51. doi:10.1097/SCS.0b013e318193d48d 
Colnot, C. (2009). Skeletal cell fate decisions within periosteum and bone marrow during bone regeneration. Journal of bone and mineral research the official journal of the American Society for Bone and Mineral Research, 24(2), 274-282.

Dhillon, K. K., Sidorova, J. M., Albertson, T. M., Anderson, J. B., Ladiges, W. C., Rabinovitch, P. S., Preston, B. D., et al. (2010). Divergent cellular phenotypes of human and mouse cells lacking the Werner syndrome RecQ helicase. DNA Repair, 9(1), 11-22. Elsevier B.V. Retrieved from http://www.ncbi.nlm.nih.gov/pubmed/19896421

Eswarakumar, V. P., Lax, I., \& Schlessinger, J. (2005). Cellular signaling by fibroblast growth factor receptors. Cytokine \& growth factor reviews, 16(2), 139-49. Oxford, UK: Elsevier Science Ltd., c1996-. doi:10.1016/j.cytogfr.2005.01.001

Fakhry, A., Ratisoontorn, C., Vedhachalam, C., Salhab, I., Koyama, E., Leboy, P., Pacifici, M., et al. (2005). Effects of FGF-2/-9 in calvarial bone cell cultures: differentiation stage-dependent mitogenic effect, inverse regulation of BMP-2 and noggin, and enhancement of osteogenic potential. Bone, 36(2), 254-66. doi:10.1016/j.bone.2004.10.003

Fanganiello, R.D., Sertié, A.L., Reis, E. M., Yeh, E., Oliveira, N. A. J., Bueno, D.F., Kerkis, I., et al. (2007). Apert p. Ser252Trp mutation in FGFR2 alters osteogenic potential and gene expression of cranial periosteal cells. Molecular Medicine, 13(7-8), 422. The Feinstein Institute for Medical Research. doi:10.2119/2007

Foster, K. A., Frim, D. M., \& McKinnon, M. (2008). Recurrence of synostosis following surgical repair of craniosynostosis. Plastic and Reconstructive Surgery, 121(3), 70e-76e. Retrieved from http://www.ncbi.nlm.nih.gov/pubmed/18317088

Freshney, R. I. (2005). Culture of animal cells: a manual of basic technique. (J. W. Sons, Ed.)4th ed New York WileyLiss (Vol. 42, p. 642). John Wiley \& Sons. doi:10.1290/BR090501.1

Furdui, C. M., Lew, E. D., Schlessinger, Joseph, \& Anderson, K. S. (2006). Autophosphorylation of FGFR1 kinase is mediated by a sequential and precisely ordered reaction. Molecular cell, 21(5), 711-7. doi:10.1016/j.molcel.2006.01.022

Ge, C., Xiao, G., Jiang, D., \& Franceschi, R. T. (2007). Critical role of the extracellular signalregulated kinase-MAPK pathway in osteoblast differentiation and skeletal development. The Journal of Cell Biology, 176(5), 709-718. The Rockefeller University Press. Retrieved from http://www.pubmedcentral.nih.gov/articlerender.fcgi?artid=2064027\&tool=pmcentrez\&renderty pe $=$ abstract

Givol, D. (1992). Complexity of FGF receptors: genetic basis for structural diversity and functional specificity. The FASEB journal official publication of the Federation of American Societies for Experimental Biology, 6(15), 3362-3369. Retrieved from http://www.fasebj.org/cgi/reprint/6/15/3362.pdf 
Glaser, R. L., Broman, K. W., Schulman, R. L., Eskenazi, B., Wyrobek, A. J., \& Jabs, Ethylin Wang. (2003). The paternal-age effect in Apert syndrome is due, in part, to the increased frequency of mutations in sperm. The American Journal of Human Genetics, 73(4), 939-947. The American Society of Human Genetics. Retrieved from http://www.pubmedcentral.nih.gov/articlerender.fcgi?artid=1180614\&tool=pmcentrez\&renderty pe $=$ abstract

Gospodarowicz, D. (1974). Localisation of a fibroblast growth factor and its effect alone and with hydrocortisone on 3 T3 cell growth. Nature, 249(453), 123-127. Retrieved from http://www.ncbi.nlm.nih.gov/pubmed/4364816

Gregory, C. A., Gunn, W. G., Peister, A., \& Prockop, D. J. (2004). An Alizarin red-based assay of mineralization by adherent cells in culture: comparison with cetylpyridinium chloride extraction. Analytical biochemistry, 329(1), 77-84. doi:10.1016/j.ab.2004.02.002

Guicheux, J., Lemonnier, J., Ghayor, C., Suzuki, A., Palmer, G., \& Caverzasio, J. (2003). Activation of p38 mitogen-activated protein kinase and c-Jun-NH2-terminal kinase by BMP-2 and their implication in the stimulation of osteoblastic cell differentiation. Journal of bone and mineral research the official journal of the American Society for Bone and Mineral Research, 18(11), 2060-2068. Retrieved from http://www.ncbi.nlm.nih.gov/pubmed/14606520

Haley, P. J. (2003). Species differences in the structure and function of the immune system. Toxicology, 188(1), 49-71. Elsevier. Retrieved from http://linkinghub.elsevier.com/retrieve/pii/S0300483X0300043X

Harries, L. W., Brown, J. E., \& Gloyn, A. L. (2009). Species-Specific Differences in the Expression of the HNF1A, HNF1B and HNF4A Genes. (B. Breant, Ed.)PLoS ONE, 4(11), 7. Public Library of Science.

Holmes, G., Rothschild, G., Roy, U. B., Deng, C.-xia, Mansukhani, A., Basilico, C., \& Basu, U. (2009). Early onset of craniosynostosis in an Apert mouse model reveals critical features of this pathology. Developmental biology, 328(2), 273-84. Elsevier Inc.

doi:10.1016/j.ydbio.2009.01.026

Hosoi, T. (2010). Genetic aspects of osteoporosis. Journal of Bone and Mineral Metabolism, 28(6), 601-607. Retrieved from http://www.ncbi.nlm.nih.gov/pubmed/20697753

Ibrahimi, O. A., Zhang, F, Eliseenkova, A. V., Itoh, N, Linhardt, R J, \& Mohammadi, M. (2004). Biochemical analysis of pathogenic ligand-dependent FGFR2 mutations suggests distinct pathophysiological mechanisms for craniofacial and limb abnormalities. Hum Mol Genet, 13, 2313-2324. doi:10.1093/hmg/ddh235

Ibrahimi, O., Zhang, Fuming, Hrstka, S. C. L., Mohammadi, Moosa, \& Linhardt, Robert J. (2004). Kinetic model for FGF, FGFR, and proteoglycan signal transduction complex assembly. Biochemistry, 43(16), 4724-30. doi:10.1021/bi0352320 
Ito, Y., Sanyal, A., Fitzsimmons, J. S., Mello, M. A., \& O’Driscoll, S. W. (2001).

Histomorphological and proliferative characterization of developing periosteal neochondrocytes in vitro. Journal of Orthopaedic Research, 19(3), 405-413. Retrieved from

http://www.ncbi.nlm.nih.gov/pubmed/11398853

Jeffrey, K. L., Brummer, T., Rolph, M. S., Liu, S. M., Callejas, N. A., Grumont, R. J., Gillieron, C., et al. (2006). Positive regulation of immune cell function and inflammatory responses by phosphatase PAC-1. Nature immunology, 7(3), 274-83. doi:10.1038/ni1310

Jehee, F. S., Krepischi-Santos, a C. V., Rocha, K. M., Cavalcanti, D. P., Kim, C. a, Bertola, D. R., Alonso, L. G., et al. (2008). High frequency of submicroscopic chromosomal imbalances in patients with syndromic craniosynostosis detected by a combined approach of microsatellite segregation analysis, multiplex ligation-dependent probe amplification and array-based comparative genome. Journal of medical genetics, 45(7), 447-50. doi:10.1136/jmg.2007.057042

Johnson, David. (2003). A comprehensive screen of genes implicated in craniosynostosis. Annals of the Royal College of Surgeons of England, 85(6), 371-377. The Royal College of Surgeons of England. Retrieved from

http://www.ingentaconnect.com/content/rcse/arcs/2003/00000085/00000006/art00001

Joiakim, A., Mathieu, P. A., Palermo, C., Gasiewicz, T. A., \& Reiners, J. J. (2003). The Jun Nterminal kinase inhibitor SP600125 is a ligand and antagonist of the aryl hydrocarbon receptor. Drug metabolism and disposition the biological fate of chemicals, 31(11), 1279-1282. Retrieved from

http://www.ncbi.nlm.nih.gov/entrez/query.fcgi?cmd=Retrieve \&db=PubMed\&dopt=Citation\&list _uids $=14570754$

Kholodenko, B. N., \& Birtwistle, M. R. (2009). Four-dimensional dynamics of MAPK information-processing systems. Cell. doi:10.1002/wsbm.016

Kimonis, V., Gold, J.-anne J., Hoffman, T. T. L., Panchal, J., \& Boyadjiev, S. A. (2007). Genetics of craniosynostosis. Seminars in Pediatric Neurology, 1-3.

doi:10.1016/j.spen.2007.08.008

Klint, P., \& Claesson-Welsh, L. (1999). Signal transduction by fibroblast growth factor receptors. Front Biosci, 4(22), D165-77. Retrieved from http://www.bioscience.org/1999/v4/d/klint/fulltext.htm

Krishna, M., \& Narang, H. (2008). Review The complexity of mitogen-activated protein kinases ( MAPKs ) made simple. Cellular and Molecular Life Sciences, 65, 3525 - 3544. doi:10.1007/s00018-008-8170-7

Lajeunie, E., Cameron, R., El Ghouzzi, V., De Parseval, N., Journeau, P., Gonzales, M., Delezoide, A. L., et al. (1999). Clinical variability in patients with Apert's syndrome. Journal Of Neurosurgery, 90(3), 443-447. Retrieved from http://www.ncbi.nlm.nih.gov/pubmed/10067911 
Langille, R. M. (1994). Chondrogenic differentiation in cultures of embryonic rat mesenchyme. Microscopy Research and Technique, 28(6), 455-469.

Lemmon, M. A., \& Schlessinger, Joseph. (2010). Cell signaling by receptor tyrosine kinases. Cell, 141(7), 1117-34. doi:10.1016/j.cell.2010.06.011

Levine, J. P., Bradley, J. P., Roth, D. A., McCarthy, J. G., \& Longaker, M T. (1998). Studies in cranial suture biology: regional dura mater determines overlying suture biology. Plastic and Reconstructive Surgery, 101(6), 1441-1447.

Li, Chaoying, Scott, D. a, Hatch, E., Tian, X., \& Mansour, S. L. (2007). Dusp6 (Mkp3) is a negative feedback regulator of FGF-stimulated ERK signaling during mouse development. Development (Cambridge, England), 134(1), 167-76. doi:10.1242/dev.02701

Lilli, C., Bellucci, C., Baroni, T., Aisa, C., Carinci, P., Scapoli, L., Carinci, F., et al. (2007). FGF2 effects in periosteal fibroblasts bearing the FGFR2 receptor Pro253 Arg mutation. Cytokine, 38(1), 22-31.

Liu, H., Liu, Y., Viggeswarapu, M., Zheng, Z., Titus, L., \& Boden, S. D. (2010). Activation of cJun NH(2)-terminal kinase 1 increases cellular responsiveness to BMP-2 and decreases binding of inhibitory Smad6 to the type I BMP receptor. Journal of bone and mineral research: the official journal of the American Society for Bone and Mineral Research, 404-417. doi:10.1002/jbmr.296

Lomri, a, Lemonnier, J., Hott, M., de Parseval, N., Lajeunie, E., Munnich, a, Renier, D., et al. (1998). Increased calvaria cell differentiation and bone matrix formation induced by fibroblast growth factor receptor 2 mutations in Apert syndrome. The Journal of clinical investigation, 101(6), 1310-7. Retrieved from http://www.pubmedcentral.nih.gov/articlerender.fcgi?artid=508685\&tool=pmcentrez\&rendertyp $\mathrm{e}=\mathrm{abstract}$

Lopez-Bergami, P., Huang, C., Goydos, J. S., Yip, D., Bar-Eli, M., Herlyn, M., Smalley, K. S. M., et al. (2007). Rewired ERK-JNK signaling pathways in melanoma. Cancer Cell, 11(5), 447460. Retrieved from http://www.pubmedcentral.nih.gov/articlerender.fcgi?artid=1978100\&tool=pmcentrez\&renderty pe $=$ abstract

Mansukhani, A., Bellosta, P., Sahni, M., \& Basilico, C. (2000). Signaling by Fibroblast Growth Factors (Fgf) and Fibroblast Growth Factor Receptor 2 (Fgfr2)-Activating Mutations Blocks Mineralization and Induces Apoptosis in Osteoblasts. The Journal of Cell Biology, 149(6), 12971308. The Rockefeller University Press. Retrieved from http://www.pubmedcentral.nih.gov/articlerender.fcgi?artid=2175120\&tool=pmcentrez\&renderty pe $=$ abstract 
Marie, P. J. (2003). Fibroblast growth factor signaling controlling osteoblast differentiation. Gene, 316, 23-32. Retrieved from

http://linkinghub.elsevier.com/retrieve/pii/S0378111903007480

Matsuguchi, T., Chiba, N., Bandow, K., Kakimoto, K., Masuda, A., \& Ohnishi, T. (2009). JNK activity is essential for Atf4 expression and late-stage osteoblast differentiation. Journal of bone and mineral research the official journal of the American Society for Bone and Mineral Research, 24(3), 398-410. Retrieved from http://www.ncbi.nlm.nih.gov/entrez/query.fcgi? $\mathrm{cmd}=$ Retrieve $\& \mathrm{db}=\mathrm{PubMed} \& d o p t=C i t a t i o n \&$ list _uids $=19016586$

McHugh, T., Wyers, M., \& King, E. (2007). MRI characterization of the glenohumeral joint in Apert syndrome. Pediatric Radiology.

De Mendonça Costa, A., Bueno, Daniela F, Martins, M. T., Kerkis, I., Kerkis, A., Fanganiello, Roberto D, Cerruti, H., et al. (2008). Reconstruction of large cranial defects in nonimmunosuppressed experimental design with human dental pulp stem cells. The Journal of craniofacial surgery, 19(1), 204-210. Retrieved from http://www.ncbi.nlm.nih.gov/pubmed/18216690

Mestas, J., \& Hughes, C. C. W. (2004). Of mice and not men: differences between mouse and human immunology. Journal of immunology (Baltimore, Md. : 1950), 172(5), 2731-8. Retrieved from http://www.ncbi.nlm.nih.gov/pubmed/14978070

Miki, T., Bottaro, D. P., Fleming, T. P., Smith, C. L., Burgess, W. H., Chan, A. M., \& Aaronson, S. A. (1992). Determination of ligand-binding specificity by alternative splicing: two distinct growth factor receptors encoded by a single gene. Proceedings of the National Academy of Sciences of the United States of America, 89(1), 246-250. Retrieved from http://www.pubmedcentral.nih.gov/articlerender.fcgi?artid=48213\&tool=pmcentrez\&rendertype $=$ abstract

Miraoui, H., Oudina, K., Petite, H., Tanimoto, Y., Moriyama, K., \& Marie, P. J. (2009).

Fibroblast growth factor receptor 2 promotes osteogenic differentiation in mesenchymal cells via ERK1/2 and protein kinase C signaling. The Journal of Biological Chemistry, 284(8), 4897-904. doi:10.1074/jbc.M805432200

Miura, T., Perlyn, C. a, Kinboshi, M., Ogihara, N., Kobayashi-Miura, M., Morriss-Kay, Gillian M, \& Shiota, K. (2009). Mechanism of skull suture maintenance and interdigitation. Journal of anatomy, 215(6), 642-55. doi:10.1111/j.1469-7580.2009.01148.x

Moloney, D. M., Slaney, S. F., Oldridge, M., Wall, S A, Sahlin, P., Stenman, G., \& Wilkie, A. O. (1996). Exclusive paternal origin of new mutations in Apert syndrome. Nature Genetics, 13(1), 48-53.

Naski, M. C., \& Ornitz, D M. (1998). FGF signaling in skeletal development. Frontiers in Bioscience, 3(4), 781-794. Informa UK Ltd UK. doi:10.3109/15513819809168795 
Ninomiya, J. T., Tracy, R. P., Calore, J. D., Gendreau, M. A., Kelm, R. J., \& Mann, K. G. (1990). Heterogeneity of human bone. Journal of bone and mineral research the official journal of the American Society for Bone and Mineral Research, 5(9), 933-938.

Oldridge, M., Zackai, E. H., McDonald-McGinn, D. M., Iseki, S., Morriss-Kay, G M, Twigg, S. R., Johnson, D, et al. (1999). De novo alu-element insertions in FGFR2 identify a distinct pathological basis for Apert syndrome. The American Journal of Human Genetics, 64(2), 446461. Retrieved from

http://www.pubmedcentral.nih.gov/articlerender.fcgi?artid=1377754\&tool=pmcentrez\&renderty pe $=$ abstract

Opperman, L A. (2000). Cranial sutures as intramembranous bone growth sites. Developmental dynamics an official publication of the American Association of Anatomists, 219(4), 472-485. Retrieved from http://www.ncbi.nlm.nih.gov/pubmed/11084647

Opperman, Lynne A, Sweeney, T. M., Redmon, J., Persing, J. A., \& Ogle, R. C. (1993). Tissue interactions with underlying dura mater inhibit osseous obliteration of developing cranial sutures. Developmental dynamics an official publication of the American Association of Anatomists, 198(4), 312-22. doi:10.1002/aja.1001980408

Ornitz, D M. (2000). FGFs, heparan sulfate and FGFRs: complex interactions essential for development. BioEssays news and reviews in molecular cellular and developmental biology, 22(2), 108-112. Am Soc Microbiol. Retrieved from

http://www.ncbi.nlm.nih.gov/pubmed/10655030

Ornitz, David M, \& Itoh, Nobuyuki. (2001). Fibroblast growth factors. Genome Biology, 2(3), reviews3005.1-reviews3005.12. BioMed Central. Retrieved from http://www.ncbi.nlm.nih.gov/pubmed/10687947

Orr-Urtreger, A., Bedford, M. T., Burakova, T., Arman, E., Zimmer, Y., Yayon, A., Givol, D., et al. (1993). Developmental localization of the splicing alternatives of fibroblast growth factor receptor-2 (FGFR2). Developmental Biology, 158(2), 475-486. Retrieved from http://www.ncbi.nlm.nih.gov/pubmed/8393815

Ozerdem, O. R., Anlatici, R., Bahar, T., Kayaselçuk, F., Barutçu, O., Tuncer, I., \& Sen, O. (2003). Roles of periosteum, dura, and adjacent bone on healing of cranial osteonecrosis. The Journal of craniofacial surgery, 14(3), 371-379; discussion 380-382.

Park, W. J., Theda, C., Maestri, N. E., Meyers, G. A., Fryburg, J. S., Dufresne, C., Cohen, M M, et al. (1995). Analysis of phenotypic features and FGFR2 mutations in Apert syndrome. The American Journal of Human Genetics, 57(2), 321-328. Retrieved from http://www.pubmedcentral.nih.gov/articlerender.fcgi?artid=1801532\&tool=pmcentrez\&renderty pe $=$ abstract

Passos-Bueno, M R, Richieri-Costa, A., Sertié, A L, \& Kneppers, A. (1998). Presence of the Apert canonical S252W FGFR2 mutation in a patient without severe syndactyly. Journal of 
Medical Genetics, 35(8), 677-679. Retrieved from

http://www.pubmedcentral.nih.gov/articlerender.fcgi?artid=1051397\&tool=pmcentrez\&renderty pe $=$ abstract

Passos-Bueno, M R, Sertié, A L, Zatz, M., \& Richieri-Costa, A. (1997). Pfeiffer mutation in an Apert patient: how wide is the spectrum of variability due to mutations in the FGFR2 gene? American Journal of Medical Genetics. Wiley Online Library. Retrieved from http://onlinelibrary.wiley.com/doi/10.1002/(SICI)1096-8628(19970808)71:2<243::AIDAJMG27>3.0.CO;2-D/abstract

Passos-Bueno, M., Sertie, A., Jehee, F., Fanganiello, R., \& Yeh, E. (2008). Genetics of craniosynostosis: genes, syndromes, mutations and genotype-phenotype correlations. Craniofacial sutures: development, disease and treatment, 12, 107-143. Karger. Retrieved from http://books.google.com/books?hl=en\&amp;lr=\&amp;id=Z59zHPG711gC\&amp;oi=fnd\&amp;pg $=$ PA107\&amp $; \mathrm{dq}=$ Genetics + of + Craniosynostosis $:+$ Genes,+ Syndromes,+ Mutations + and + Genot ype-Phenotype+Correlations\&amp;ots=XqFsP_CjX\&amp;sig=zWLyP6XNE7FxjsjSU2Q2c0PwDB4

Patterson, K. I., Brummer, T., Brien, P. M. O., Daly, R. J., \& O’BRIEN, P. M. (2009). Dualspecificity phosphatases : critical regulators with diverse cellular targets. Biochemical journal, 418(2009), 475-489. Portland Press. doi:10.1042/BJ20082234

Posnick, J. C., Armstrong, D., \& Bite, U. (1995). Crouzon and Apert syndromes: intracranial volume measurements before and after cranio-orbital reshaping in childhood. Plastic and Reconstructive Surgery, 96(3), 539-548.

Renier, D., Arnaud, E., Cinalli, G., Marchac, D., Brunet, L., Sebag, G., Sainte-Rose, C., et al. (1996). Mental prognosis of Apert syndrome. Archives of Pediatrics, 3(8), 752-760.

Roth, D. A., Bradley, J. P., Levine, J. P., McMullen, H. F., McCarthy, J. G., \& Longaker, M T. (1996). Studies in cranial suture biology: part II. Role of the dura in cranial suture fusion. Plastic and Reconstructive Surgery, 97(4), 693-699.

Scadden, D. T. (2006). The stem-cell niche as an entity of action. Nature, 441(7097), 1075-9. doi:10.1038/nature04957

Schlessinger, J, Plotnikov, A. N., Ibrahimi, O. A., Eliseenkova, A. V., Yeh, B. K., Yayon, A., Linhardt, R J, et al. (2000). Crystal structure of a ternary FGF-FGFR-heparin complex reveals a dual role for heparin in FGFR binding and dimerization. Molecular Cell, 6(3), 743-750.

Retrieved from http://www.ncbi.nlm.nih.gov/pubmed/11030354

Shaul, Y. D., \& Seger, R. (2007). The MEK/ERK cascade: from signaling specificity to diverse functions. Biochimica et biophysica acta, 1773(8), 1213-26. doi:10.1016/j.bbamcr.2006.10.005 
Shukla, V., Coumoul, X., Wang, R.-hong, Kim, H.-seok, \& Deng, C.-xia. (2007). RNA interference and inhibition of MEK-ERK signaling prevent abnormal skeletal phenotypes in a mouse model of craniosynostosis. Nature Genetics, 39(9), 1145-1150. doi:10.1038/ng2096

Slater, B. J., Lenton, K. A., Kwan, M. D., Gupta, D. M., Wan, D. C., \& Longaker, Michael T. (2008). Cranial sutures: a brief review. Plastic and Reconstructive Surgery, 121(4), 170e-8e. Retrieved from http://www.ncbi.nlm.nih.gov/pubmed/18349596

Squier, C. A., Ghoneim, S., \& Kremenak, C. R. (1990). Ultrastructure of the periosteum from membrane bone. Journal of Anatomy, 171, 233-239. Retrieved from http://www.ncbi.nlm.nih.gov/pubmed/2081707

Su, N., Sun, Q., Li, Can, Lu, X., Qi, H., Chen, S., Yang, J., et al. (2010). Gain-of-function mutation in FGFR3 in mice leads to decreased bone mass by affecting both osteoblastogenesis and osteoclastogenesis. Human Molecular Genetics, 19(7), 1199-1210. Oxford University Press. Retrieved from http://www.ncbi.nlm.nih.gov/pubmed/20053668

Tolarova, M. M., Harris, J. A., Ordway, D. E., \& Vargervik, K. (1997). Birth prevalence, mutation rate, sex ratio, parents' age, and ethnicity in Apert syndrome. American Journal of Medical Genetics, 72(4), 394-398.

Trueb, B., Zhuang, L., Taeschler, S., \& Wiedemann, M. (2003). Characterization of FGFRL1, a novel fibroblast growth factor (FGF) receptor preferentially expressed in skeletal tissues. The Journal of Biological Chemistry, 278(36), 33857-33865. Retrieved from http://www.ncbi.nlm.nih.gov/pubmed/12813049

Wang, Y., Sun, M., Uhlhorn, V. L., Zhou, X., Peter, I., Martinez-Abadias, N., Hill, C. A., et al. (2010). Activation of p38 MAPK pathway in the skull abnormalities of Apert syndrome Fgfr2+P253R mice. BMC Developmental Biology, 10, 22. BioMed Central. Retrieved from http://www.pubmedcentral.nih.gov/articlerender.fcgi? artid=2838826\&tool=pmcentrez\&renderty pe $=$ abstract

Wang, Y., Xiao, R., Yang, F., Karim, B. O., Iacovelli, A. J., Cai, J., Lerner, C. P., et al. (2002). Abnormalities in cartilage and bone development in the Apert syndrome FGFR2 + / S252W mouse. Development. doi:10.1242/dev.01914

Wilkie, A. O. (1997). Craniosynostosis: genes and mechanisms. Human Molecular Genetics, 6(10), 1647-1656. Retrieved from http://www.ncbi.nlm.nih.gov/pubmed/9300656

Wilkie, A. O. M., Byren, J. C., Hurst, J. a, Jayamohan, J., Johnson, David, Knight, S. J. L., Lester, T., et al. (2010). Prevalence and complications of single-gene and chromosomal disorders in craniosynostosis. Pediatrics, 126(2), e391-400. doi:10.1542/peds.2009-3491

Wilkie, A. O., \& Morriss-Kay, G M. (2001). Genetics of craniofacial development and malformation. Nat Rev Genet, 2, 458-468. doi:10.1038/35076601 
Wilkie, A. O., Slaney, S. F., Oldridge, M., Poole, M. D., Ashworth, G. J., Hockley, A. D., Hayward, R. D., et al. (1995). Apert syndrome results from localized mutations of FGFR2 and is allelic with Crouzon syndrome. Nature Genetics, 9(2), 165-172.

Yang, F., Wang, Y., Zhang, Z., Hsu, B., Jabs, Ethylin Wang, \& Elisseeff, J. H. (2008). The study of abnormal bone development in the Apert syndrome Fgfr2+/S252W mouse using a 3D

hydrogel culture model. Bone, 43(1), 55-63. Retrieved from

http://www.ncbi.nlm.nih.gov/pubmed/17707711

Yeh, E. (2011). Estudo da contribuição molecular e celular do periósteo na craniossinostose da síndrome de Apert. Universidade de São Paulo.

Yeh, E., Atique, R., Ishiy, F., Fanganiello, R., Alonso, N., Matsushita, H., \& Passos-bueno, M. R. (2011). FGFR2 Mutation Confers a Less Drastic Gain of Function in Mesenchymal Stem Cells Than in Fibroblasts. Stem Cell Reviews and Reports. doi:10.1007/s12015-011-9327-6

Zollikofer, C. P. E., \& Ponce De León, M. S. (2010). The evolution of hominin ontogenies. Seminars in cell developmental biology, 21(4), 441-452. Retrieved from http://www.ncbi.nlm.nih.gov/pubmed/19900572 